\title{
Identification of a new factor essential for vacuolar aminopeptidase I activity
}

\author{
Dissertation \\ zur Erlangung des Doktorgrades \\ der Mathematisch-Naturwissenschaftlichen Fakultäten \\ der Georg-August-Universität zu Göttingen
}

\author{
vorgelegt von \\ Pasupuleti Naga Rekha \\ aus Hyderabad (Indien)
}


D7

Referent:

Prof. Dr. Kurt von Figura

Korreferent:

Prof. Dr. Gerhard Gottschalk

Tag der mündlichen Prüfung: 03.11.2004 
To

Mom, Dad and Sis.... 



\section{Contents}

Abbreviations ................................................................... IV

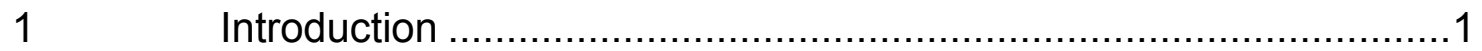

1.1 The yeast vacuole .....................................................

1.2 Delivery of proteins to the vacuole ......................................... 1

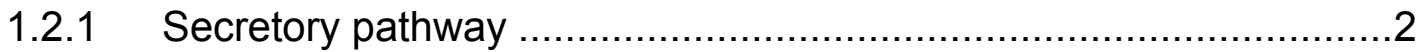

1.1.2 Autophagy and Cytoplasm-to-vacuole-targeting (Cvt) pathway .......4

1.2.2.1 Induction ............................................................................. 6

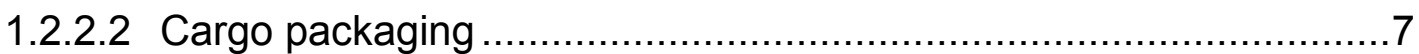

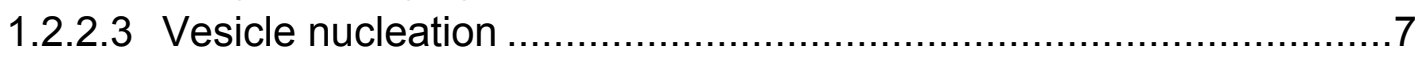

1.2.2.4 Vesicle expansion and completion ...........................................8

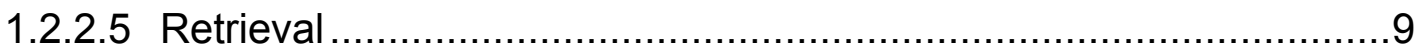

1.2.2.6 Vesicle targeting, docking and fusion................................... 9

1.2.2.7 Vesicle breakdown ............................................................ 10

1.3 Aminopeptidase $I$..................................................... 10

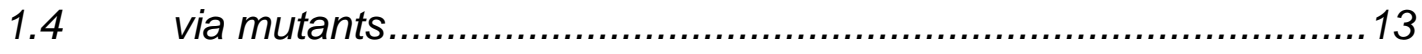

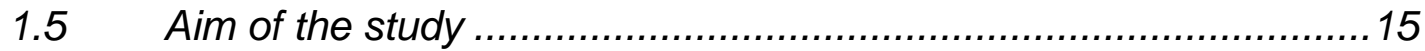

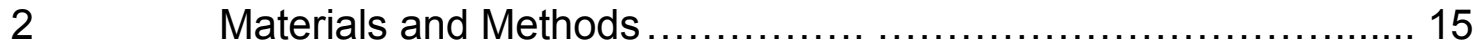

$2.1 \quad$ Materials .......................................................................... 15

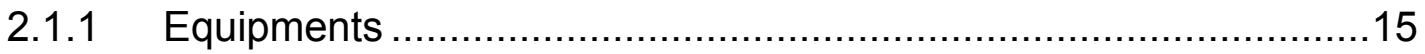

2.1.2 Materials for molecular biology and biochemical experiments .......15

2.1.3 Materials for Western Blotting .............................................. 16

2.1.4 Chemicals .............................................................................

2.1.5 Oligonucleotides for PCR ................................................... 16

2.1.6 Enzymes and Substrates .................................................. 18

2.1.7 Proteins, Protease inhibitors and Protein standards .....................18

2.1.8 Vectors and DNA standards ............................................... 18

2.1.9 Radioactive substances ..................................................... 19

2.1.10 Kits for DNA, RNA and Protein...............................................19

2.1 .11 Antibodies ..................................................................... 19

2.1.12 Yeast Strains....................................................................... 20

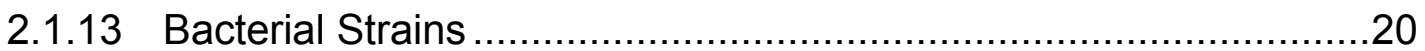

2.1.14 Media for S. cerevisiae cells................................................20 
2.1.15 Media for Escherichia coli .....................................................22

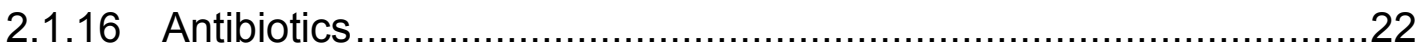

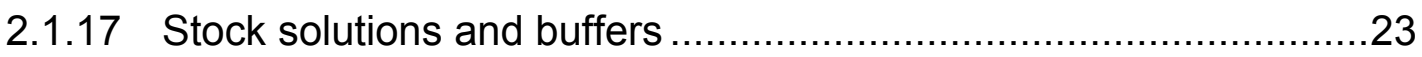

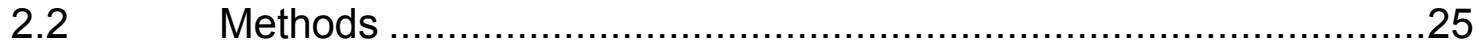

2.2.1 MOLECULAR BIOLOGY ......................................................25

2.2.1.1 Protocols for E.coli ............................................................. 25

Preparation of competent E. coli ............................................25

Transformation of competent E.coli .....................................25

Preparation of electrocompetent E.coli.................................26

Transformation of the electrocompetent E.coli ...........................26

Glycerol stocks of bacterial strains ........................................ 26

Mini preparation of plasmid DNA from E.coli ............................27

Midi preparation of plasmid DNA from E.coli ..............................28

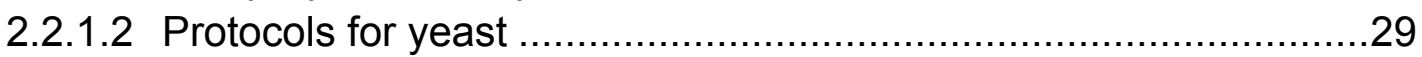

Transformation of yeast cells- Chemical Method .........................29

Glycerol stocks of yeast cells .............................................29

Isolation of genomic DNA from Yeast.....................................30

Isolation of plasmid DNA from Yeast ..........................................31

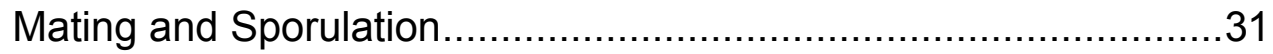

2.2.1.3 Protocols for DNA / RNA ............................................... 32

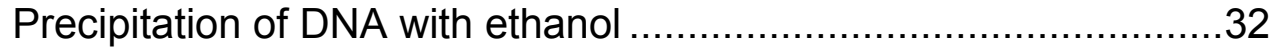

Determining the concentration of DNA .................................... 32

Restriction endonuclease digestion of DNA .............................32

Agarose gel electrophoresis of DNA ......................................33

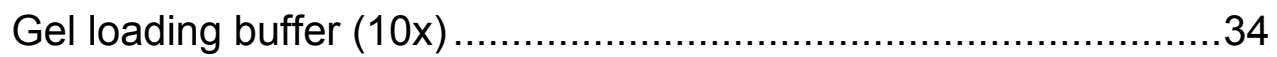

Cloning and DNA ligation .................................................... 34

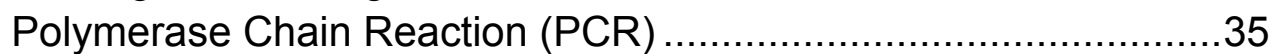

Site directed mutagenesis ................................................. 36

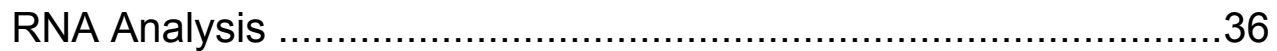

Isolation of total yeast RNA using RNAeasy kit ..........................36

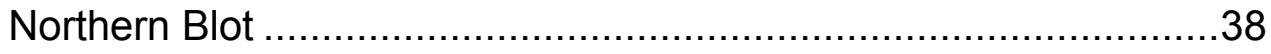

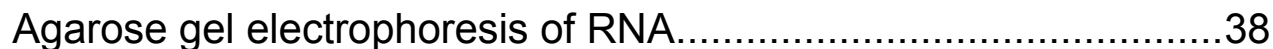

2.2.2 BIOCHEMICAL METHODS.................................................40

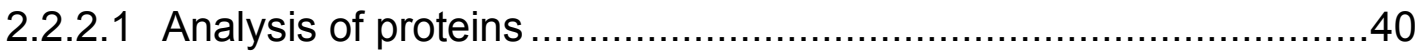

Determination of protein concentration using BIORAD reagent..............40

Precipitation of proteins using Trichloroacetic acid (TCA) ......................40

Solubilisation of proteins ..............................................................4

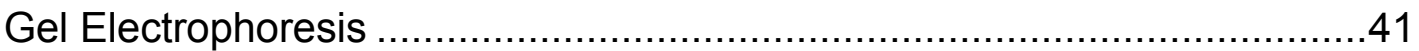

Staining of Polyacrylamide gels ..........................................................43

a. Coomassie blue staining ….......................................................... 43

b. Silver Staining ............................................................................ 43

2.2.2.2 Western blot analysis (semi dry method) ............................44 
Detection techniques

a. Chemiluminescent Substrate from PIERCE .........................45

b. Luminol Detection system .............................................45

Stripping the antibody from the membrane ..............................46

2.2.2.4 Protein extracts from S.cerevisiae ...........................................4 47

Spheroplasting ................................................................................. 47

Preparation of yeast cell lysates .......................................................48

a. Preparation of cell lysates using glass beads.........................48

b. Preparation of cell lysates using DEAE dextran ......................49

2.2.2.5 Subcellular fractionation .................................................... 49

2.2.2.6 Glycerol Density Gradients .................................................49

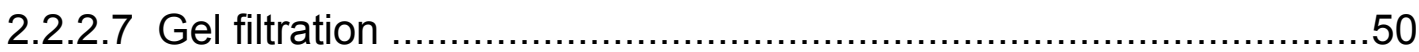

2.2.2.8 Ape1p activity by overlay assay........................................51

2.2.2.9 Immunofluorescence microscopy........................................52

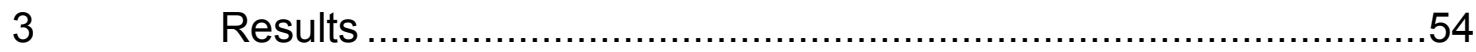

3.1.1 SUVIA1 is a suppressor of via mutants .................................56

3.1.2 Ape1p expression and processing is enhanced by Suvia1p .........57

3.1.3 Suvia1p enhances dodecamerization of pApe1p ......................60

3.1.4 Suvia1p is required for Ape1p enzymatic activity .......................61

3.2 Characterization of Suvia1p .........................................62

3.2.1 HA-tagged Suvia1p complements Suvia1p-deficiency.................62

3.2.2 Suvia1p is a cytosolic protein ...........................................65

3.2.3 Suvia1p appears to be part of $200 \mathrm{kDa}$ complex.......................66

3.2.4 Immunofluorescence microscopy of Suvia-1p...........................67

3.2.5 Suvia1p and Atg8p do not colocalize.............................67

3.3 Interaction of Suvia1p with Aminopeptidase I............................69

3.4 Analysis of via10 and via14 genes ..................................73

3.4.1 Microarray studies ........................................................... 73

3.4.2 Analysis of down-regulated genes in via mutants ......................75

3.4.3 Rescue of Ape1p activity in the via mutants............................77

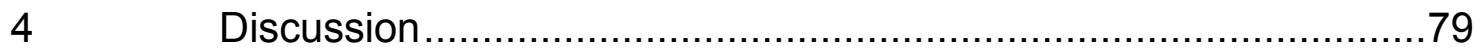

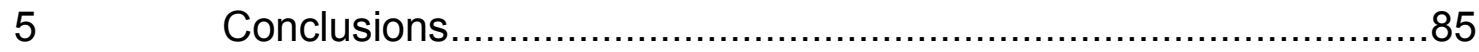

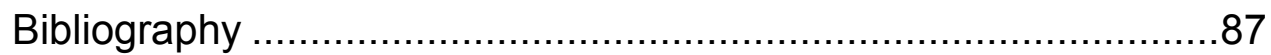




\section{Abbreviations}

aa

Amp

APE1(or LAPIV)

Ape1p

APS

ATP

BSA

cDNA

ct

$\mathrm{dd}_{2} \mathrm{O}$

DEPC

DMSO

DNA

dNTPs

DTT

E. coli

EDTA

ER

$\mathrm{EtOH}$

Fig

GFP

GST

$\mathrm{h}$

HEPES

HPLC

HRP

$\lg G$

IPTG
Amino acid

Ampicillin

Aminopeptidase I gene

Aminopeptidase 1

Ammoniumperoxodisulfate

Adenosine 5'-triphosphate

Bovine Serum Albumin

complementary DNA

Control

double distilled water

Diethyl pyrocarbonate

Dimethylsulfoxide

Deoxyribonucleicacid

Deoxynucleosidetriphosphate (dATP, dGTP, dCTP, dTTP)

Dithiothreitol

Escherichia coli

Ethylenediamintetraacetate-Disodium salt

Endoplasmic Reticulum

Ethanol

Figure

Green fluorescent protein

Glutathione-S-Transferase

Hour

N-2-Hydroxyethylpiperazin-N'-2-ethanesulfonic acid

High performance liquid chromatogryphy

Horseradish-Peroxidase

Immunoglobulin $\mathrm{G}$

Isopropyl-a-D-Thiogalactopyranoside 
kb

$\mathrm{kDa}$

I

LB

$M$

$\mathrm{mA}$

$\mathrm{mg}$

$\min$

$\mathrm{ml}$

$\mathrm{mM}$

MOPS

$\mathrm{nm}$

OD

PAGE

pApe1p

PCR

$\mathrm{pH}$

PMSF

RNA

rpm

RT

S. cerevisiae

SDS

sec

SNARE

TAE

TBS

TCA

TE

TEMED

Tris

U
Kilobase

Kilodalton

Liter

Luria Bertani

Molar

Milliampere

Milligram

Minute

Milliliter

Millimolar

Morpholinoethane sulfonic acid

Nanometer

Optical density

Poly-acrylamide gel electrophoresis

Precursor aminopeptidase I

Polymerase chain reaction

Negative logarithm of $\mathrm{H}^{+}$concentration

Phenylmethylsulfonylfluoride

Ribonucleicacid

Revolutions per minute

Room Temperature

Saccharomyces cerevisiae

Sodium Dodecyl Sulfate

Seconds

Soluble N-ethylmalimide Attachment protein Receptor

Tris-Acetate-EDTA-Buffer

Tris buffer saline

Trichloroaceticacid

Tris-EDTA-Buffer

$\mathrm{N}, \mathrm{N}, \mathrm{N}^{\prime}, \mathrm{N}$ '-Tetramethylethylenediamine

Tris-(hydroxymethyl)-aminomethane

Unit 
UV

$\mathrm{V}$

$\mathrm{v} / \mathrm{v}$

Vti1a

$\mathrm{w} / \mathrm{v}$

wt

YPD

$\mu$
Ultraviolet

Volt

(volume/volume)

Vps10p interacting

(weight/volume)

Wild type

Yeast Peptone Dextrose

Micro 


\section{Introduction}

\subsection{The yeast vacuole}

The vacuole in yeast is the analogous organelle to lysosomes in mammalian cells. It has an acidic $\mathrm{pH}$ and is rich in hydrolases. The yeast vacuole is the biggest organelle occupying up to $60 \%$ of the cell volume. During cell division portions of the vacuole are targeted to the growing bud.

Vacuole is integrally involved in a wide array of physiological processes which include:

- $\mathrm{pH}$ and osmoregulation: yeasts mutants with impaired vacuolar functions have reduced viability in media of extreme $\mathrm{pH}$ and osmotic strength.

- Protein metabolism: During periods of nitrogen starvation, amino acid supplies are maintained by protein degradation that takes place in the vacuole. Proteinase $A$ and proteinase $B$ are two vacuolar resident endopeptidases responsible for the activation of exopeptidases in the vacuole.

- Diploids lacking vacuolar protease activities fail to sporulate indicating the importance of vacuolar proteolysis for the survival and differentiation of the organism (Raymond et al, 1992; Teichert et al, 1989). The vacuole serves as the store house for basic amino acids, small ions and polyphosphates. Hydrolase-deficient yeast cells do not survive long periods of starvation.

Thus the vacuole is involved in various and diverse processes, which necessitate the presence of a specific group of hydrolases and transmembrane proteins.

\subsection{Delivery of proteins to the vacuole}

Vacuolar hydrolases are compartmentalized in the organelle to prevent non-specific cellular damage. There are four pathways by which proteins are known to enter the vacuole. These are the secretory pathway, endocytosis, autophagocytosis and the cytosol-to-vacuole-targeting or Cvt pathway. Vacuolar resident proteins are either transported by the secretory or the Cvt pathway and proteins destined for degradation are transported by autophagocytosis and endocytosis. For example, mating pheromones and their receptors are endocytosed and delivered to the vacuole and degraded in a PEP4 (proteinase A) dependent manner (Sanger and 
Reizman, 1990; Dulic and Reizman, 1989; Konopka et al., 1986). The other pathways are discussed in detail in the following chapters.

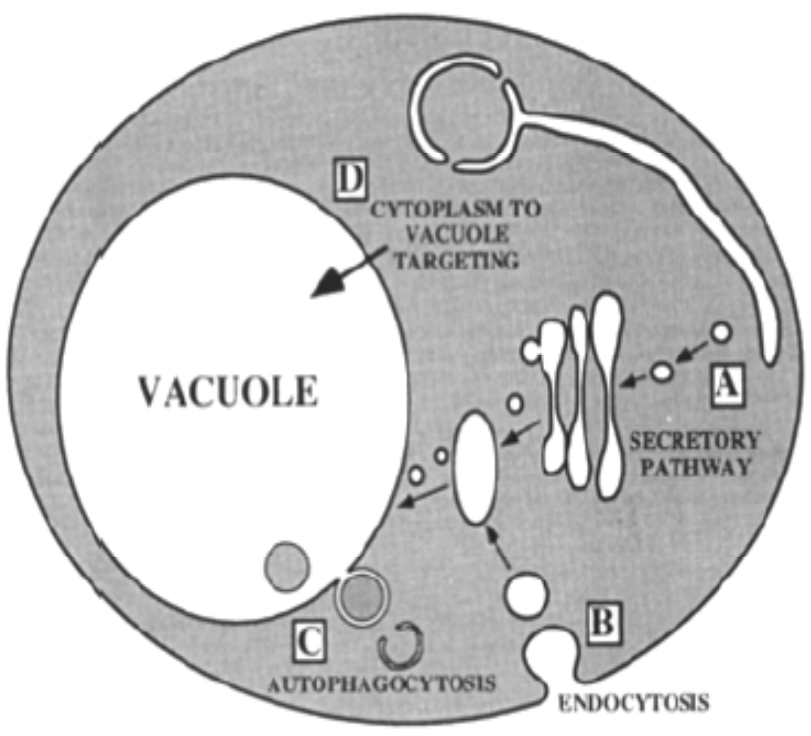

Fig 1: Four routes for the delivery of proteins into the yeast vacuole (Harding et al., 1995).

\subsubsection{Secretory pathway}

The secretory pathway is utilized in eukaryotic cells to sort and transport proteins from their site of synthesis to several intracellular organelles or plasmamembrane and the periplasma. Most of the vacuolar resident proteins are known to enter the vacuole by this pathway. Proteins are synthesized on ER-bound ribosomes and translocated into the lumen of the ER. There exists an amino terminal cleavable or a non-cleavable internal hydrophobic signal which targets the protein to the ER membrane (Rapoport et al., 1996 Ann. Rev. Biochem). Cleavage of the signal sequence releases the proteins into the lumen of the ER. $\mathrm{N}$-linked carbohydrate addition occurs co-translationally. Proteins are then delivered via transport vesicles to the Golgi complex, where they undergo further post-translational modifications of the carbohydrate side chains before being sorted in a late Golgi compartment, the transgolgi network (TGN) away from proteins to be secreted.

In yeast, vacuolar proteins such as carboxypeptidase $Y$ (CPY), proteinase $A$ and proteinase $B$ transit the early stages of the secretory pathway before being sorted in a late Golgi compartment. 
CPY is a serine peptidase which has been studied extensively and is used as a marker protein to follow the vacuolar transport along the secretory pathway. CPY is synthesized as a prepro-precursor molecule and translocated into the ER lumen, where its signal sequence is cleaved off to form pro-CPY (Stevens et al., 1982, Blachy-Dyson \& Stevens 1987, Johnson et al 1987). pro-CPY receives N-linked core gylcosylation in the ER, which results in a $67 \mathrm{kDa}$ form known as p1-CPY. In the Golgi complex, extension of the core oligosaccharides results in an increase in the apparent molecular weight of CPY to $69 \mathrm{kDa}$; this form is known as p2-CPY. Finally, p2-CPY is proteolytically processed in a proteinase $A$ and proteinase $B$ dependent manner (Mechler et al., 1987) to generate the $61 \mathrm{kDa}$ enzymatically active mature form, referred to as m-CPY. It is made up of a single subunit of $61 \mathrm{kDa}$, out of which $10 \mathrm{kDa}$ is carbohydrate in the form of $\mathrm{N}$-linked oligosaccharides (Hasilik and Tanner, 1978a). Overproduction of CPY results in missorting and secretion. The secreted CPY is in its Golgi-p2-CPY form. Missorting due to overproduction demonstrates the presence of a saturable limiting component, such as a receptor molecule that facilitates its recognition and/or sorting to the vacuole. The sorting receptor Vps10p is responsible for the vacuolar delivery of CPY. Vps10p binds p2-CPY in the late Golgi sorting compartment, and the receptor-ligand complex is delivered to $a$ prevacuolar/endosomal compartment. In the endosome, CPY dissociates from the receptor and the receptor is recycled back to the sorting compartment for another round of protein transport. p2-CPY then moves on to the vacuole, where it is processed to its mature form. 


\subsubsection{Autophagy and Cytoplasm - to - vacuole - targeting (Cvt) pathway}

Autophagy is a vacuolar trafficking pathway that targets cytosolic proteins and compartments to the vacuole for degradation. The word "autophagy" is derived from Greek 'self' (auto) and 'to eat' (phagy) i.e. 'to eat oneself'. It is the primary intracellular catabolic mechanism for degrading and recycling long-lived proteins and organelles of the yeast cell. It occurs as a cellular response to both extracellular stress conditions as nutrient starvation and intracellular stress conditions as accumulation of damaged organelles and proteins. Two types of autophagy have been identified, microautophagy and macroautophagy that involve rearrangement of subcellular membranes to sequester cargo for delivery to the vacuole, where the sequestered material is degraded and recycled.

Microautophagy involves the engulfment of cytoplasm directly by the vacuolar membrane, by invagination, protrusion and/or septation of the vacuolar limiting membrane. In contrast, macroautophagy involves the formation of cytosolic doublemembrane vesicles, distinct from the vacuoles called autophagosomes, into which portions of the cytoplasm are sequestered. Fusion of an autophagosome with the vacuole results in the delivery of a single membrane autophagic body into the lumen of the vacuole, where the autophagic bodies are degraded. In yeast, autophagy occurs primarily by macroautophagy, based on electron microscopic studies of nitrogen-starved cells (Baba et al., 1994).

Autophagy in yeast was studied by three distinct genetic screens. Apg deficient mutants were selected based on the ability of the mutants to grow in nitrogen starvation media (Tsukada and Ohsumi, 1993). Aut deficient mutants were selected based on the failure to degrade fatty acid synthase (Thumm et al., 1994).

A screen for the mutants the accumulating the cytoplasmic precursor form of aminopeptidase I yielded Cvt mutants which largely overlapped with mutants of the autophagic pathway (Harding et al., 1995, 1996).

Recently the nomenclature of the involved proteins/genes was unified to Atg for autophagy to avoid the confusion with different names of the Apg, Aut and Cvt mutants.

Genetic screens to follow peroxisome degradation and glucose-induced autophagy did not reveal unique genes for these pathways so far. 
The cytoplasm-to-vacuole-targeting (Cvt) pathway is an example of a specific type of autophagy; proteins that are destined to become resident vacuolar hydrolases as aminopeptidase I and $\alpha$-mannosidase are specifically packaged into cytoplasmic vesicles called cvt vesicles and delivered to the vacuole. This pathway is active under nutrient-rich conditions. The Cvt pathway converts into autophagy under nutrient starvation conditions. Aminopeptidase $\mathrm{I}$ is then found in autophagosomes.

\section{Starvation: Autophagy}

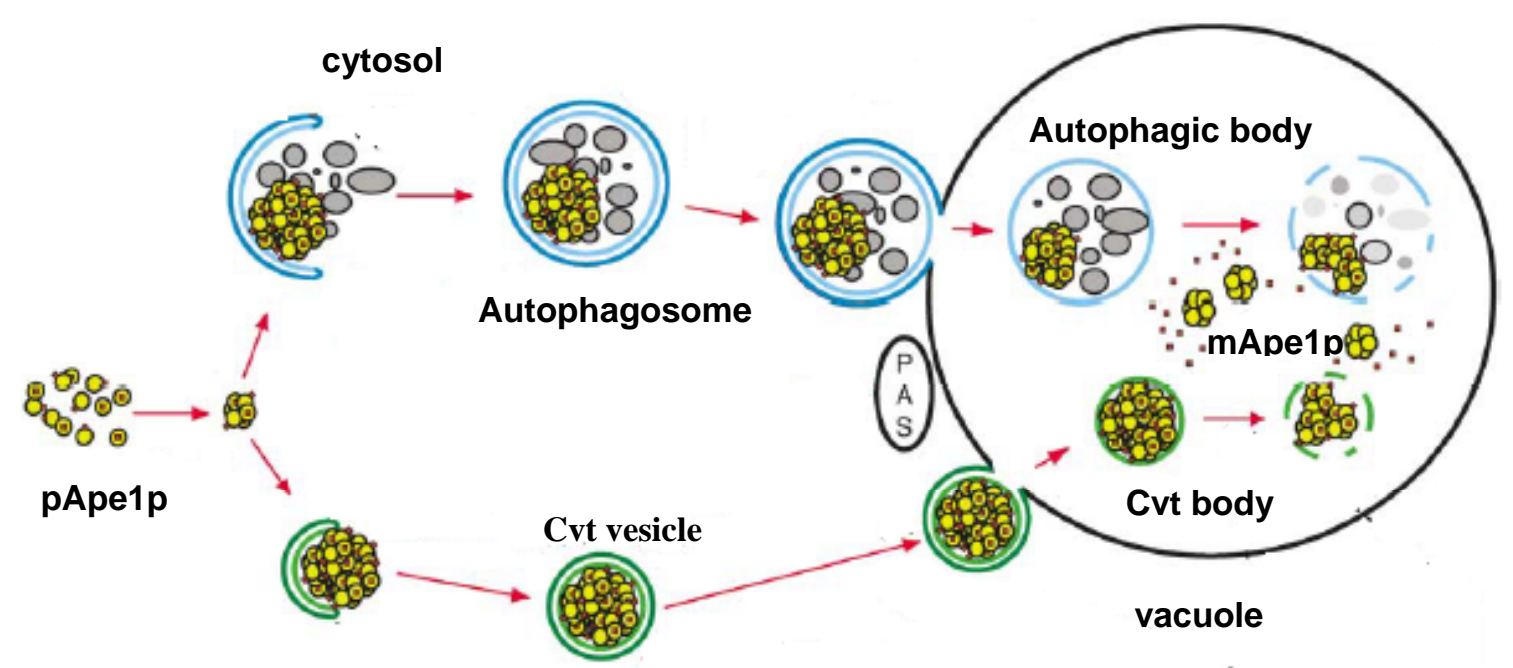

\section{Nutrient rich conditions: Cvt pathway}

Fig 2: Autophagy and Cvt pathway are active under different physiological conditions (Levine and Klionsky, 2004).

A number of differences distinguish the two modes of transport, such as Ape1p transport is a specific biosynthetic event that is constitutive, occuring even under nutrient- rich conditions (Klionsky et al., 1992; Scott et al., 1996). Bulk autophagy is non-selective, degradative, and only detectable during starvation for nutrients such as nitrogen or carbon (Takeshige et al., 1992). Also pApe1p has a half-time for vacuolar delivery of 30-45 min (Klionsky et al., 1992), while the half time for delivery of cytosolic proteins by macroautophagy is at least $12 \mathrm{~h}$ when induced by nitrogen starvation (Scott et al., 1996). Morphologically, cvt vesicles seen in rapidly growing cells are smaller than their autophagosome counterparts. Cvt vesicles are approximately $150 \mathrm{~nm}$ in diameter while autophagosomes are approximately 300-900 
nm (Takeshige, et al.,1992). Finally, the Cvt pathway is specific (excluding bulk cytoplasm) and saturable, while autophagy is non-specific and is not saturable.

Despite these differences, the morphology of autophagy and the Cvt pathways are very similar. Most of the molecular machinery overlaps between the two pathways, except that the Cvt pathway uses components that are required for the specific packaging of cargo. Autophagosomal receptors e.g. for peroxisomes have not been identified.

The major events of autophagy and Cvt pathways are induction (only for autophagy), cargo selection (only in case of Cvt pathway) and packaging, vesicle nucleation, vesicle expansion, retrieval of components, vesicle docking and fusion and finally vesicle breakdown.

\subsubsection{Induction}

The degradative autophagic pathway is induced upon starvation through a mechanism that involves the protein kinase Tor, a phosphatidyl inositol (PI)-related serine/threonine kinase. Tor acts as the nutrient-sensing element that regulates autophagy (Noda T and Ohsumi Y., 1998). In response to starvation, Tor kinase is inhibited which results in the induction of autophagosome formation.

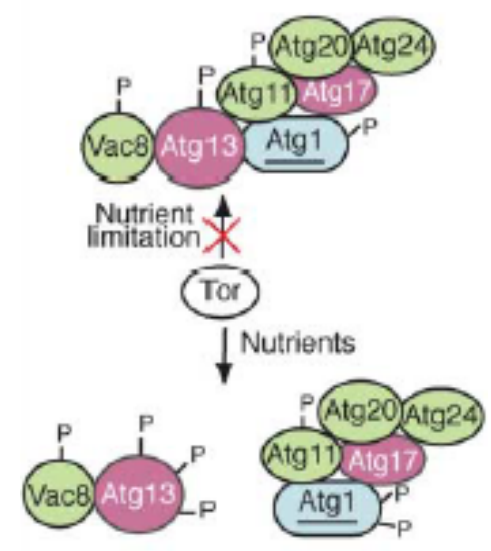

Fig 3: Regulation of induction by Tor kinase (Levine and Klionsky, 2004).

The Tor-mediated inductive signal for autophagy appears to be transduced through the phosphoprotein Atg13 and the serine/threonine kinase Atg1 (Kamada et al; 
2000). Both of these proteins are required for Cvt vesicle and autophagosome formation (Matsuura et al; 1997). Inhibition of Tor causes partial dephosphorylation of Atg13. This hypophosphorylated form of Atg13 has a higher affinity for Atg1 kinase. In vitro assays demonstrate that Atg1 kinase activity is essential for both Cvt and autophagy. Other proteins that interact with Atg1 complex are shown in figure 3.

\subsubsection{Cargo packaging}

The Cvt pathway is a cargo specific autophagic process that uses additional components that are involved in the recognition and packaging of dodecamers of pApe1p cargo, which then bind to the Atg19 that has characteristics of both a receptor and an adaptor protein for Cvt cargo, the aminopeptidase I and the $\alpha$ mannosidase I. Atg19 is localized to punctuate structures or near the vacuole. Atg19 is a peripheral membrane protein that binds to the the cargo and travels to the vacuole with the cargo (Scott et al., 2001). Subsequent interaction of Atg19 with Atg11 brings the cargo into contact with the ubiquitin-like protein Atg8 and allows its inclusion into the sequestering vesicle that is formed from the preautophagosomal structure (PAS).

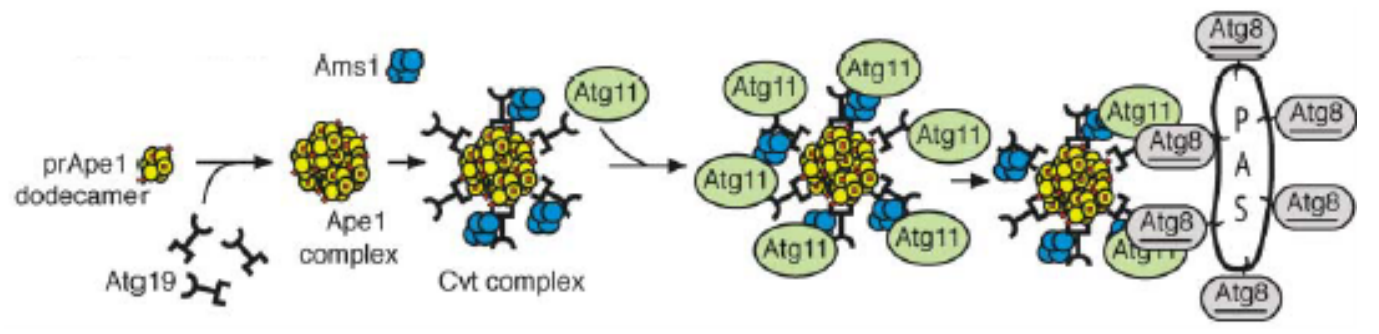

Fig 4: Cargo selection and packaging (Levine and Klionsky, 2004).

\subsubsection{Vesicle nucleation}

Unlike vesicle formation throughout the endomembrane system involving ER, Golgi complex etc, autophagic vesicles do not appear to bud off from pre-existing organelles. Rather, the vesicle is thought to form de novo. However, the source of vesicle membrane is unknown. Phosphoinositol kinases (PI) may play a fundamental role in vesicle nucleation (Kihara et al 2001). 
The PI 3-kinase complex I, including Vps34, Vps15 serine/threonine kinase together with Atg6/Nps30 and Atg14, functions in vesicle nucleation in both autophagy and Cvt pathway.

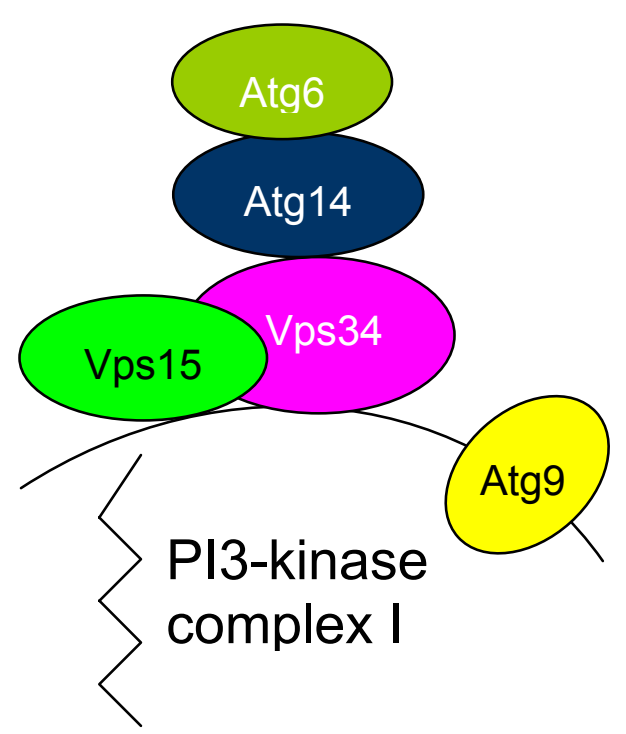

Fig 5: Phosphoinositol-3 kinase Vps34 plays a role in vesicle nucleation (Levine and Klionsky, 2004).

\subsubsection{Vesicle expansion and completion}

Majority of proteins involved in autophagy and Cvt pathway act at the step of vesicle formation. The mechanism by which the double membrane enwraps and sequesters cytoplasmic components is not known. Recent studies have identified several genes as being part of a novel conjugation system required for autophagy and Cvt vesicle formation. Atg8 (ubiquitin-like protein), undergoes two post-translational processing events resulting in conjugation with phosphatidyl-ethanolamine (PE) and recruitment to the PAS membrane. The Atg7 protein is homologous to E1 ubiquitin activating enzymes and is required for the activation of Atg8 as well as Atg12, a second ubiquitin-like protein. Atg12 is covalently linked via its carboxy-terminal glycine to an internal lysine residue of Atg5. A novel coiled-coil protein Atg16 has been shown to physically bind the Atg12-Atg5 conjugate and oligomerization of Atg16 allows the formation of a multimeric complex. The conjugation process also requires Atg4, Atg3 and $\operatorname{Atg} 10$. 


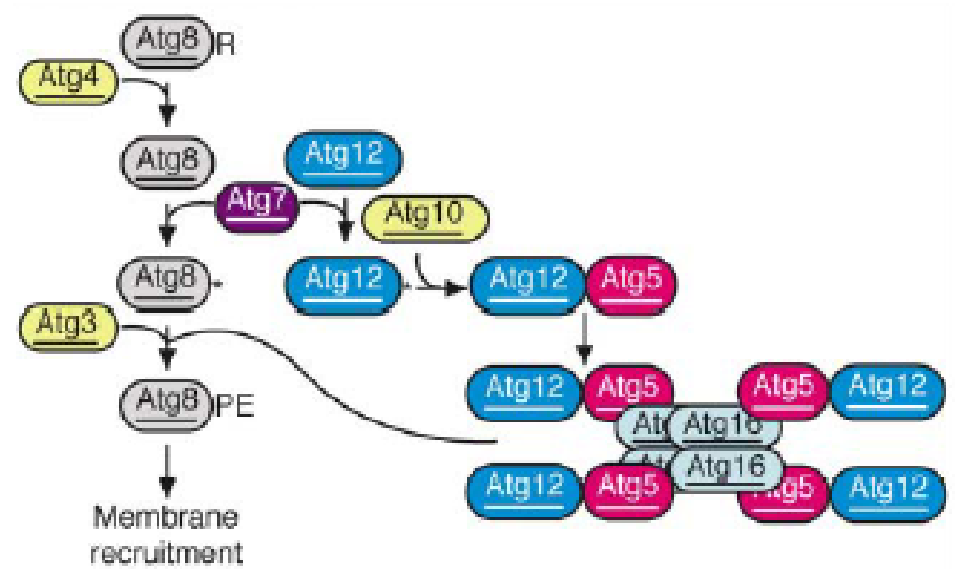

Fig 6: Conjugation of Atg8 to PE and Atg12 to Atg5 is required for the vesicle formation (Levine and Klionsky, 2004).

\subsubsection{Retrieval}

Retrograde trafficking processes are used to retrieve certain components for reutilization. Atg8 is the only structural protein known to remain with the completed autophagosome or Cvt vesicle. Other proteins that are thought to act at the stage of vesicle formation are not associated with the autophagosome suggesting that they are retrieved at some point prior to, or up to, vesicle completion. The integral membrane protein Atg9 is removed through a specific retrieval process involving Atg2 and Atg18.

\subsubsection{Vesicle targeting, docking and fusion}

The components required for the fusion of Cvt vesicles and autophagosomes with the vacuole are common to all the pathways that terminate at the vacuole. Ccz1 and Mon1, have been shown to function at the tethering or docking stage that brings the vesicles into proximity with the vesicles before fusion (Wang and Klionsky, 2003). 


\subsubsection{Vesicle breakdown}

The double membranous vesicle loaded with the cytoplasmic cargo fuses with vacuolar membrane releasing the single membrane autophagic body into the lumen of the vacuole.The single membrane autophagic body is broken down to degrade the cytoplasmic components. The vesicle breakdown is known to depend on the acidic $\mathrm{pH}$ of the vacuolar lumen, and proteinase B. Atg15 is a putative lipase that reaches the vacuole through the secretory, multivesicular body pathway and is required for the breakdown of Cvt and autophagic bodies (Teter et al., 2001).

\subsection{Aminopeptidase I}

There are four identified aminopeptidases in S.cerevisiae that hydrolyze preferentially leucine substrates (Trumbly and Bradley, 1983). Of these, only animopeptidase I (previously called LAPIV) appears to be localized to the vacuole based on subcellular fractionation studies (Matile et al., 1971; Frey and Röhm, 1978).

Ape1p catalyzes the removal of leucine from the N-terminus of polypeptide chains. Aminopeptidase I is encoded by the APE1 gene located on chromosome XI. It has been shown that Ape $1 p$ is synthesized as an inactive zymogen that is processed in a PEP4-dependent manner (Chang and Smith, 1989, Trumbly and Bradley, 1983; Cueva et al., 1989) like all other soluble vacuolar proteins that transit through the secretory pathway.

The APE1 gene encodes a protein of 514 amino acids containing four potential sites for N-linked glycosylation (Cueva et al; 1989). The active enzyme is a multimeric protein having a molecular mass of approximately $600 \mathrm{kDa}$. The mature Ape $1 \mathrm{p}$ monomer has a molecular mass of 50-51 kDa based on its migration pattern on SDSPAGE (Metz and Röhm, 1976; Chang and Smith, 1989). The molecular mass based on the amino acid composition is predicted to be a protein of approximately $45 \mathrm{kDa}$ (Metz and Röhm, 1976). The maturation of Ape1p from its precursor form has been shown to be a 2 step process. The $61 \mathrm{kDa}$ cytoplasmic pApe $1 \mathrm{p}$ is proteolytically matured to a $55 \mathrm{kDa}$ intermediate form and $50 \mathrm{kDa}$ vacuolar mApe1p form by the sequential action of the two vacuolar proteinases PrA and PrB (Segui-Real et al., 1995). Ape $1 p$ does not follow the secretory pathway which was concluded from the following observations. 
- The N-terminus of pApe1p does not have the typical structure of a ERtargeting sequence. Using various temperature sensitive sec mutants, defective in the secretory pathway, it was shown that Ape1p does not enter the secretory pathway.

- Using tunicamycin, which blocks the addition of $\mathrm{N}$-linked oligosaccharides to proteins, and Concanavalin A, to which both $\mathrm{N}$-linked and O-linked oligosaccharides bind, it was shown that aminopeptidase 1 is not glycosylated, even though it has four potential glycosylation sites (Klionsky et al., 1992).

- Ape1p has a half time of 45 min for vacuolar delivery, compared to a half time of approximately $6 \mathrm{~min}$ for CPY, proteinase A or alkaline phosphatase (ALP) (Klionsky and Emr, 1989; Klionsky et al., 1988; Hasilik and Tanner, 1978).

- Overproduction of CPY and PrA leads to their secretion, but over expressed Ape1p is not secreted (Klionsky et al., 1992).

These observations led to the conclusion, that Ape1p is transported directly from the cytosol into the vacuole along the cytosol to vacuole targeting pathway.

The precursor form of Ape1p contains an amino-terminal 45 amino acid propeptide. The propeptide lacks a consensus signal sequence. Ape1p propeptide is not necessary for folding of the mature portion of Ape $1 p$ polypeptide, but instead plays a direct role in the entry of Ape1p into the vacuole. The predicted secondary structure for the pApe1p propeptide is composed of an amphipathic $\alpha-$ helix followed by a $\beta$-turn and another $\alpha$-helix forming a helix-turn-helix structure. Using NMR spectroscopy it has been shown that mutations, which destabilize the first $\alpha$-helix inhibit the transport of pApe1p (Martinez et al., 1997). pApe1p targeting is sensitive to changes in periodicity and content of the predicted amphipathic $\alpha$-helix, but is insensitive to similar changes in the second helix (Oda et al., 1996).

It has been shown that the prepro-part of Ape1p is necessary and sufficient to target the protein into the vacuole. This was shown by tagging GFP to the preprosequence of pApe1p. This construct was targeted into the vacuole and the reporter protein was released. They have also shown that the separated pre- and pro-parts do not target GFP to the vacuole (Martinez et al., 1999).

The following evidences suggest that the transport of $\mathrm{pApe} 1 \mathrm{p}$ is a vesicular event. 
- Analysis of cvt mutants indicate that a substantial overlap between genes involved in pApe1p transport and those required for autophagy. In addition, phenotypic examination of $c v t$ and autophagy mutants revealed that the majority of these mutants are both autophagy defective and accumulate pApe1p precursor forms (Harding et al., 1996; Scott et al., 1996).

- Several studies indicated that Ape1p enters the vacuole as a dodecamer. Pulse chase experiments suggested that oligomerisation is an early event in transport (Kim et al., 1997). The half time for transport of Ape1p into the vacuole is about $45 \mathrm{~min}$ while the half time of oligomerisation is about 2 min. Mutants in cvt pathway or propeptide deletion mutants are shown to be defective only in the import step and not in the oligomerisation. The import into the vacuole appears to be the rate limiting step (Kim et al., 1997). Transport of a large oligomer into the vacuole appears to be similar to the transport of large pre-assembled oligomeric complexes into the peroxisomal lumen (Rachubinski and Subramani, 1995; Subramani, 1993). It has been suggested that the oligomeric precursor Ape1p is enwrapped by a double membrane (Baba et al., 1997, Scott et al., 1997) and this cvt vesicle transports Ape1p into the vacuole. 


\section{4 via mutants}

Based on the enzymatic activity of the dodecameric complex, a new genetic screen was developed for analyzing the biogenesis pathway of aminopeptidase 1 and two complementation groups were characterized termed as via for vacuolar import and autophagocytosis (Andrei et al., 2000). Enzymatic activity of mature and dodecameric mApe1p was measured by Ape1p overlay assay using leucine- $\beta$ naphthylamide as substrate. via mutants have reduced activity and show reduced levels of Ape $1 p$ expression compared to the wt.

Two complementation groups were identified namely via10 and via14. Both via mutants accumulate pApe1p in membrane enclosed compartments demon-strating defects in pApe1p transport. While this compartment in via10 was similar to the wt vesicles, the via14 vesicles were extremely fragile and displayed reduced density when compared to wt cells, thus demonstrating a severe defect in Cvt vesicle biogenesis.

In wt cells $p A p e 1 p$ and mApe1p of Ape $1 p$, form stable dodecameric complexes whereas in both via mutants, the assembly of pApe1p into dodecamers is disturbed. pApe $1 p$ in via mutants does not form stable dodecameric complexes, demonstrating defects in complex assembly and formation of high molecular weight aggregates. Vacuolar mApe1p is found in dodecameric complexes in via mutants, but these are not enzymatically active indicating that cytoplasmic oligomerization is essential for the formation of active enzyme complexes. This supports the Cvt pathway and makes translocation mechanism across the vacuolar memebrane unlikely.

According to the model for the Cvt pathway (Scott and Klionsky, 1996) pApe1p rapidly dodecamerizes in the cytoplasm and is then enwrapped by a double membrane. In via mutants, formation of the surrounding membrane takes place, but pApe $1 \mathrm{p}$ is not properly assembled; smaller complexes and aggregates are formed. This phenotype was not described previously in the cvt and autophagy mutants studies so far.

Protease protection experiments reveal that pApe1p accumulates in Cvt vesicles in via mutants. Processing of pApe1p is delayed, but can be up-regulated by inducing autophagy. However this does not restore enzymatic activity. This explains a specific defect in the Cvt pathway and that dodecamerization of pApe1p is linked to the Cvt pathway. The accumulation of pApe1p in Cvt vesicles demonstrates that complex 
formation and vesicular transport is disturbed, indicating that formation of transport vesicles and dodecamerization are linked processes. Further more it was discovered that the cytoplasmic pApe1p is enzymatically active unlike the peptidases transported along the secretory pathway.

Coupling of pApe $1 \mathrm{p}$ dodecamerization and compartmentalization into transport vesicle, is thus a mechanism to protect cytosolic proteins from Ape $1 p$ activity. 


\subsection{Aim of the study}

A new genetic screen was developed for analyzing the biogenetic pathway of aminopeptidase I based on the enzymatic activity of the dodecameric complex which led to the isolation of via mutants.

The aim of this project was to identify the via genes as well as single-copy suppressors of the via mutant phenotypes. Characterization of the corresponding gene products should give us insights into the mechanisms involved in the formation of enzymatically active dodecameric Ape1p complexes and the Cvt pathway. 


\section{Materials and Methods}

\section{$2.1 \quad$ Materials}

\subsubsection{Equipments}

Electroporator 1000

Gene quant II, RNA/DNA calculator

Intelligent Dark Box II, LAS-1000+

Phosphoimager Fujix BAS1000

Ultra turrax T8

SMART System for HPLC

Mastercycler gradient
Stratagene, USA

Pharmacia Biotech, UK

Fuji, Japan

Fuji, Japan

IKA Labortechnik, Staufen

Amersham Pharmacia Biotech

Eppendorf, Hamburg

\subsubsection{Materials for molecular biology and biochemical experiments}

Autoclave bags

Bottle top filters

Centrifuge tubes:

JA-10 Polypropylene tube

JA-20 Polypropylene tube

Culture flasks for bacteria

Glass pipettes

Microscope slides

Needles for syringes

Parafilm

Pasteur pipettes

Pipette tips

Plastic tubes 10, 15 and $50 \mathrm{ml}$

Polycarbonate ultracentrifuge tubes $1,5 \mathrm{ml}$

Superdex 200 column
Sarstedt, Nümbrecht

Sarstedt Inc., Newton, USA

Nalgene, München

Nalgene, München

Schott, Mainz

Schütt, Göttingen

Menzel-Glaser

B.Braun Melsungen AG,

Melsungen

American National Can ${ }^{\mathrm{TM}}$

Chicago

Schütt, Göttingen

Sarstedt, Nümbrecht

Sarstedt, Nümbrecht

Beckman, München

Amersham Pharmacia Biotech

Uppsala, Sweden. 


\subsubsection{Materials for Western Blotting}

Nitrocellulose membrane $0.2 \mu \mathrm{M}$

Schleicher and Schüll, Dassel

Whatman GB002 paper

Schleicher and Schüll, Dassel

Whatman GB003 paper extra thick

Schleicher and Schüll, Dassel

X-ray films XAR-5

Kodak, Stuttgart

Supersignal Chemiluminiscent Substrate

Pierce, Illinois/ USA

Luminol and p-coumaric acid

Sigma

\subsubsection{Chemicals}

All chemicals were bought from

Boehringer / Roche, Mannheim;

Merck, Darmstadt;

Roth, Karlsruhe;

Serva, Heidelberg;

Sigma, Deisenhofen,Gibco BRL

All the chemicals were of analysis grade.

\subsubsection{Oligonucleotides for PCR}

\begin{tabular}{|l|l|l|}
\hline \multicolumn{1}{|c|}{ Name } & \multicolumn{1}{|c|}{ Oligonucleotide } & \multicolumn{1}{c|}{ Purpose } \\
\hline PSYDR1 5' & CGG ATA GCC TCT GGT TAG GT & $\begin{array}{l}\text { Amplification of } \\
\text { SUVIA }\end{array}$ \\
\hline PSYDR2 3' & TTG AGC CGG GGC ATA CAG GT & $\begin{array}{l}\text { Amplification of } \\
\text { SUVIA }\end{array}$ \\
\hline PSYB1 5' & TTT ATT AAA TTT GGA TCC TTC AAT & $\begin{array}{l}\text { Introduction of } \\
\text { BamHI site in SUVIA }\end{array}$ \\
\hline PSYB2 3' & ATT GAA GGA TCC AAA TTT AAT AAA & $\begin{array}{l}\text { Introduction of } \\
\text { BamHI site in SUVIA }\end{array}$ \\
\hline PSYH1 5' & $\begin{array}{l}\text { CCT TAT CCC TTC AAG CTT CGG TTC } \\
\text { GAA AGG }\end{array}$ & HindlII site in SUVIA \\
\hline PSYH2 3' & $\begin{array}{l}\text { CCT TTC GAA CCG AAT CTT GAA GGG } \\
\text { ATA AGG }\end{array}$ & HindlII site in SUVIA \\
\hline
\end{tabular}




\begin{tabular}{|c|c|c|}
\hline 10YHR1 5' & AAG CTA TTC ATG GTA CCC GCT GC & $\begin{array}{l}\text { Amplification of } \\
\text { YHR054C }\end{array}$ \\
\hline 10YHR2 3' & GGT AAT GGG ATC GGC TTA CTA ATT & $\begin{array}{l}\text { Amplification of } \\
\text { YHR054C }\end{array}$ \\
\hline 10YJL1 5 & AGA CAA ATG TTA CAG AGT ATA GTC & $\begin{array}{l}\text { Amplification of } \\
\text { YJL171C }\end{array}$ \\
\hline 10YJL2 3' & CAA TGA CTT AAA ATC TCA AAA C & $\begin{array}{l}\text { Amplification of } \\
\text { YJL171C }\end{array}$ \\
\hline 14YER1 5 & GTG GGG TAT ACT ACG GAG CAT GG & $\begin{array}{l}\text { Amplification of } \\
\text { YER187W }\end{array}$ \\
\hline 14YER2 3' & GTC AACAGT TCT TAA TTT CGG GTC & $\begin{array}{l}\text { Amplification of } \\
\text { YER187W }\end{array}$ \\
\hline 14YGL117W & $\begin{array}{l}\text { CAA TAT CTT ACA ATG CAG CCA ATT } \\
\text { TC }\end{array}$ & $\begin{array}{l}\text { Amplification of } \\
\text { YGL117W }\end{array}$ \\
\hline 14YGL117W & $\begin{array}{l}\text { GTC AAA TTA TCA TAT AAC CCT TCT } \\
\text { ATG }\end{array}$ & $\begin{array}{l}\text { Amplification of } \\
\text { YGL117W }\end{array}$ \\
\hline PNACT1 5 & CAC GCT TAC TGC TTT TTT CTT CCC & Amplification of actin \\
\hline PNACT2 3' & $\begin{array}{l}\text { GAG AGC TAC ATA CAT AAA CAT ACG } \\
\text { C }\end{array}$ & Amplification of actin \\
\hline PNYHRKO1 & $\begin{array}{l}\text { AAA GCT ATT CAT GGT ACC CGC TGC } \\
\text { TGA AAA CCT ATC TCC GAC GGA TCC } \\
\text { CCG GGT TAA TTA A }\end{array}$ & Deletion of YHR054C \\
\hline PNYHRKO2 & $\begin{array}{l}\text { GCA CGT ATA GCG CCC AAA TGT CGG } \\
\text { TAA TGG GAT CGG CTT AGA ATT CGA } \\
\text { GCT CGT TTA AAC }\end{array}$ & Deletion of YHR054C \\
\hline
\end{tabular}




\subsubsection{Enzymes and Substrates}

Lysozyme

Restriction endonucleases

Zymolyase 20T

H-Leu- $\beta$-Napthyl Amide (H-Leu- $\beta-N A$ )
Merck

New England biolabs

Seikagaku Corporation

BACHEM

\subsubsection{Proteins, Protease inhibitors and Protein standards}

Antipain

Bovine Serum Albumin (BSA)

Chymostatin

Elastin

Glutathione-sepharose

lodoacetamide

Leupeptin

Protein A sepharose

Protein $\mathrm{G}$ agarose

Pepstatin A

Phenylmethylsulfonylfluoride (PMSF)

Prestained protein molecular

weight markers
Sigma

Serva

Sigma

Sigma

Amersham-Pharmacia

Sigma

Biomol

Amersham-Pharmacia

Calbiochem

Biomol

Serva

Biorad

\subsubsection{Vectors and DNA standards}

pCR2.1

pBluescript

pGEX-2T

pYX

pRS
Invitrogen

Stratagene

Pharmacia Biotech

Dr. G.Fischer Von Mollard

Sikorski and Hieter,1989 


\subsubsection{Radioactive substances}

$\alpha-\left[{ }^{32} \mathrm{P}\right]-\mathrm{dCTP}, 3000 \mathrm{Ci} / \mathrm{mmol}$

Hartmann Analytic, Braunschweig

\subsubsection{Kits for DNA, RNA and Protein}

$\begin{array}{ll}\text { Bio-Rad Protein Assay } & \text { Bio-Rad } \\ \text { HiSpeed plasmid midi kit } & \text { Qiagen } \\ \text { HiSpeed plasmid mini kit } & \text { Qiagen } \\ \text { Megaprime DNA Labelling mix } & \text { Amersham-Pharmacia } \\ \text { RNeasy midi kit } & \text { Qiagen } \\ \text { QIAquick Gel extraction kit } & \text { Qiagen }\end{array}$

\subsubsection{Antibodies}

\begin{tabular}{|c|c|c|c|}
\hline Primary Antibody & $\begin{array}{l}\text { Immunized } \\
\text { Species }\end{array}$ & $\begin{array}{c}\text { Dilution for } \\
\text { western } \\
\text { blot }\end{array}$ & Reference \\
\hline anti-aminopeptidase-I & Rabbit & $1: 2000$ & Andrei et al.,2000 \\
\hline anti-GFP & Mouse & $1: 3000$ & MBL \\
\hline anti-GST & Goat & $1: 3000$ & MBL \\
\hline anti-HA & Mouse & $1: 1000$ & Dr.Fischer von Mollard \\
\hline
\end{tabular}

Secondary antibodies

Goat anti-rabbit Horseradish peroxidase conjugate

Goat anti-mouse Horseradish peroxidase conjugate

Rabbit anti-goat Horseradish peroxidase conjugate

All secondary antibodies were diluted 1:10000

All secondary antibodies were purchased from Dianova, Hamburg. 


\subsubsection{Yeast Strains}

Strain

SEY6211

MATa, ura3-52, his3 $\Delta 1$, leu2-3,-112, trp1-289, suc2-D9, ade

II-17 MAT $\alpha$, ura3-52, his3 $\Delta 1$, leu2-3,-112, trp1-289, suc2-D9, ade

C6C

BY4741 MAT $\alpha$, his $3 \Delta 1$, leu $2 \Delta 0$, met $15 \Delta 0$, ura $3 \Delta 0$, YDR360w::kanMX4

suvia1d $\quad$ C6C X BY4741 SEY6211 X C6C

\section{Genotype}

Source

Prof. S. Emr

Prof.D.H.Wolf

\subsubsection{Bacterial Strains}

Strain

\section{Genotype}

XL1-Blue

recA1,endA1, gyrA96, thi-1, hsdR17,supE44, relA1

Source

Stratagene

Heidelberg

\subsubsection{Media for S. cerevisiae cells}

YPD Medium

$$
\begin{aligned}
& 20 \text { g Peptone } \\
& 10 \text { g Yeast extract } \\
& 20 \text { g Dextrose }
\end{aligned}
$$

To prepare $1000 \mathrm{ml}$ of YPD medium, Peptone $(20 \mathrm{~g})$ and Yeast extract (10 g) were dissolved in $900 \mathrm{ml}$ of $\mathrm{ddH}_{2} \mathrm{O}$ and autoclaved. After autoclaving, $100 \mathrm{ml}$ of $20 \%$ autoclaved Dextrose $(20 \mathrm{~g})$ stock solution was added. 


\section{YPD Agar Plates}

$2 \%$ of Bacto-agar $(20 \mathrm{~g}), 20 \mathrm{~g}$ of peptone and $10 \mathrm{~g}$ of yeast extract were dissolved in $900 \mathrm{ml}$ of $\mathrm{ddH}_{2} \mathrm{O}$ and autoclaved. After autoclaving $100 \mathrm{ml}$ of $20 \%$ sterile Dextrose $(20 \mathrm{~g})$ stock solution was added and the mixture was poured in $10 \mathrm{~cm}$ petriplates.

$\begin{array}{ll}\text { Presporulation Medium } & 2 \% \text { Peptone } \\ & 1 \% \text { Yeast Extract } \\ & 5 \% \text { Glucose }\end{array}$

Starvation Medium

$5 \mathrm{~g}$ Sodium Acetate

$10 \mathrm{~g}$ Potassium Chloride

$15 \mathrm{~g}$ Bacto-agar. Dissolved in

$1000 \mathrm{ml}$ of water and autoclaved.

Synthetic minimal medium (SD)

$6.7 \mathrm{~g}$ yeast nitrogen base w/o amino acids

$20 \mathrm{~g}$ Dextrose

To prepare $1000 \mathrm{ml}$ of synthetic minimal medium, yeast nitrogen base w/o amino acids and supplements mixture were mixed and autoclaved. After autoclaving, 100 $\mathrm{ml}$ of $20 \%$ autoclaved Dextrose $(20 \mathrm{~g})$ stock solution was added and poured in $10 \mathrm{~cm}$ petriplates.

Supplements and their concentration used are listed in the table below

\section{Supplements and the concentration used :}

\begin{tabular}{|l|c|c|}
\hline \multicolumn{1}{|c|}{ Supplements } & $\begin{array}{c}\text { Final } \\
\text { Concentration(mg/l) }\end{array}$ & Stock per 100ml \\
\hline Adenine sulphate & 20 & $200 \mathrm{mg}$ \\
\hline L-Tyrosine & 30 & $300 \mathrm{mg}$ \\
\hline L-Phenylalanine & 50 & $500 \mathrm{mg}$ \\
\hline L-Glutamic acid & 100 & $1000 \mathrm{mg}$ \\
\hline
\end{tabular}




\begin{tabular}{|l|c|c|}
\hline L-Methionine & 20 & $200 \mathrm{mg}$ \\
\hline L-Isoleucine & 30 & $300 \mathrm{mg}$ \\
\hline L-Lysine-HCl & 30 & $300 \mathrm{mg}$ \\
\hline L-Valine & 150 & $1500 \mathrm{mg}$ \\
\hline L-Serine & 375 & $3750 \mathrm{mg}$ \\
\hline Uracil & 20 & $200 \mathrm{mg}$ \\
\hline L-Leucine & 30 & $300 \mathrm{mg}$ \\
\hline L.Typtophan & 20 & $200 \mathrm{mg}$ \\
\hline L-Histidine & 20 & $200 \mathrm{mg}$ \\
\hline
\end{tabular}

All the solutions were autoclaved.

\subsubsection{Media for Escherichia coli}

Luria Bertani (LB) medium

$10 \mathrm{~g}$ Bacto-Tryptone

$5 \mathrm{~g}$ Bacto-yeast extract

$5 \mathrm{~g} \mathrm{NaCl}$

Dissolved in $900 \mathrm{ml}$ distilled water, $\mathrm{pH}$ adjusted to 7.0 with $10 \mathrm{~N} \mathrm{NaOH}$, made up the volume to one liter, sterilized by autoclaving and stored at room temperature.

LB-Ampicillin Agar Plates

$1.5 \%$ of Agar was added to the LB medium and autoclaved. After autoclaving, the medium was let to cool down to $55^{\circ} \mathrm{C}$ and ampicillin was added to a final concentration of $100 \mu \mathrm{g} / \mathrm{ml}$. The medium was poured into $10 \mathrm{~cm}$ petriplates.

\subsubsection{Antibiotics}

Ampicillin $25 \mathrm{mg} / \mathrm{ml}$

Dissolved in water. $\mathrm{pH}$ was set to 8.0 with $10 \mathrm{~N}$ Sodium hydroxide. Filter sterilized and aliquots stored at $-20{ }^{\circ} \mathrm{C}$.

Working concentration $\quad 100 \mu \mathrm{g} / \mathrm{ml}$

Kanamycin $25 \mathrm{mg} / \mathrm{mlDissolved} \mathrm{in} \mathrm{water.} \mathrm{Sterile} \mathrm{filtered}$ 
Working concentration

and stored aliquots at $-20^{\circ} \mathrm{C}$.

$50 \mu \mathrm{g} / \mathrm{ml}$

\subsubsection{Stock solutions and buffers}

1 M DTT

$3.08 \mathrm{~g}$

$181.1 \mathrm{~g}$

$\underline{0.5 \mathrm{M} \text { EDTA }}$

$181.1 \mathrm{~g}$

Ethidium Bromide $\quad 0.2 \mathrm{~g}$

$\underline{0.1 \mathrm{M} \mathrm{IPTG}}$

$23.8 \mathrm{mg}$

$10 \times$ PBS

$80 \mathrm{~g}$

$1.6 \mathrm{~g}$
Dissolved in $20 \mathrm{ml}$ of $0.01 \mathrm{M}$ sodium acetate $\mathrm{pH}$ was 5.2. Filter sterilized and aliquots stored at $-20^{\circ} \mathrm{C}$.

Ethylene Diamine Tetra Acetic acid (sodium salt) dissolved in $800 \mathrm{ml}$ of water, $\mathrm{pH}$ was set to 8.0 with $\mathrm{NaOH}$. Volume was made up to $100 \mathrm{ml}$ and autoclaved.

Dissolved in $20 \mathrm{ml}$ of water, stored at $4{ }^{\circ} \mathrm{C}$.

Dissolved in $1 \mathrm{ml}$ of water.

Sterile, filtred and aliquots stored at $20{ }^{\circ} \mathrm{C}$.

Sodium chloride

Disodium hydrogen phosphate dissolved in $800 \mathrm{ml}$ water. Volume was made up to $1000 \mathrm{ml}$.

1.25 mg/ml Leupeptin

$0.75 \mathrm{mg} / \mathrm{ml}$ Antipain

$0.25 \mathrm{mg} / \mathrm{ml}$ Chymostatin

$0.25 \mathrm{mg} / \mathrm{ml}$ Elastin 
$5.0 \mathrm{mg} / \mathrm{ml}$ Pepstatin dissolved in

DMSO, aliquots stored at $-20{ }^{\circ} \mathrm{C}$.

$\underline{3 \mathrm{M} \text { Sodium acetate }}$

$2.5 \mathrm{M}$ Sorbitol

$\underline{50 \times \mathrm{TAE}}$

$\underline{\operatorname{TBS}(1 \mathrm{x})}$

$\underline{\text { IE }}$

$1 \mathrm{M}$ Tris/ $\mathrm{HCl}$

$1 \mathrm{M}$ Tris / SO4
$227.7 \mathrm{~g} \quad$ Dissolved in water. Volume was made upto $500 \mathrm{ml}$, sterilized by autoclaving.

$242 \mathrm{~g} \quad$ Tris base

$57.1 \mathrm{~g} \quad$ glacial acetic acid $100 \mathrm{ml}$ of $0.5 \mathrm{M}$ EDTA ( $\mathrm{pH} 8.0$ )

Dissolved in water and the final volume was made upto one litre.

$150 \mathrm{mM}$ Sodium chloride

$10 \mathrm{mM} \quad$ Tris/ $\mathrm{HCl} \mathrm{pH} 7.4$

$10 \mathrm{mM} \quad$ Tris/ $\mathrm{HCl} \mathrm{pH} 7.5$

$1 \mathrm{mM} \quad$ EDTA

121.1g Tris-Base dissolved in $800 \mathrm{ml}$ water. $\mathrm{pH}$ was set to the required value with conc. $\mathrm{HCl}$. Volume was made upto $1000 \mathrm{ml}$ and autoclaved.

121.1g Tris-base dissolved in $800 \mathrm{ml}$ of 
water, pH was set to 9.4 .

\subsection{Methods}

\subsubsection{MOLECULAR BIOLOGY}

\subsubsection{Protocols for E.coli}

\section{Preparation of competent E. coli}

\section{Buffers}

TFB I

$30 \mathrm{mM}$ Calcium acetate, $\mathrm{pH} 5.8$

100 mM Rubidium chloride

$10 \mathrm{mM}$ Calcium chloride

$50 \mathrm{mM}$ Manganese chloride

$15 \%$ Glycerol (w/v)

TFB II

10 mM MOPS, $\mathrm{pH} 6.5$

$75 \mathrm{mM}$ Calcium chloride

10 mM Rubidium chloride

$15 \%(w / v)$ Glycerol

2-3 $\mathrm{ml}$ bacterial pre-culture was grown in LB medium at $37^{\circ} \mathrm{C}$, overnight. $1 \mathrm{ml}$ of the pre-culture was inoculated into LB medium $(99 \mathrm{ml})$ and grown at $37^{\circ} \mathrm{C}$ to an OD 600 of 0.4-0.6. Cells were pelleted at $3000 \mathrm{rpm}$ for $5 \mathrm{~min}$ at $4{ }^{\circ} \mathrm{C}$, resuspended in 0.2 culture volume of TFB I and incubated on ice for $5 \mathrm{~min}$. Cells were centrifuged at $3000 \mathrm{rpm}$ for $5 \mathrm{~min}$ at $4{ }^{\circ} \mathrm{C}$, the pellet was resuspended in 0.04 culture volume of TFB II and incubated on ice for $30 \mathrm{~min}$. Aliquots of $50 \mu \mathrm{l}$ were frozen at $-80{ }^{\circ} \mathrm{C}$.

\section{Transformation of competent E.coli}

50-100 ng of DNA was added to each $50 \mu$ aliquot of competent cells and incubated on ice for $30 \mathrm{~min}$. Cells were subjected to heat shock by incubating at $42{ }^{\circ} \mathrm{C}$ for $2 \mathrm{~min}$ and incubated on ice for $1-2 \mathrm{~min} .0 .9 \mathrm{ml}$ of LB medium was added to the cells followed by incubation at $37^{\circ} \mathrm{C}$ in the shaker for 1 hour. Cells were plated on LB-agar plates containing appropriate antibiotic and incubated overnight at $37^{\circ} \mathrm{C}$. For bluewhite selection, cells were plated on plates containing IPTG (Isopropyl- $\beta$-D- 
thiogalactopyranoside; $40 \mu \mathrm{l}$ of $100 \mathrm{mM}$ solution in water) and X-Gal (40 $\mu \mathrm{l} \mathrm{of} 4 \%$ solution in dimethylformamide).

\title{
Preparation of electrocompetent E.coli
}

$10 \%(\mathrm{v} / \mathrm{v})$ Glycerol: $1 \mathrm{ml}(1.26 \mathrm{~g})$ of glycerol in $10 \mathrm{ml}$ sterile water

A single E. coli colony was inoculated into $10 \mathrm{ml}$ of LB media and allowed to grow overnight at $37^{\circ} \mathrm{C}$ in a shaking incubator. This pre-culture was inoculated in 1 I LB media and allowed to grow to an OD 600 of $0.5-0.7$ at $37^{\circ} \mathrm{C}$. Cells were pre-chilled on ice for $15 \mathrm{~min}$ and then pelleted at $5000 \mathrm{rpm}$ for $15 \mathrm{~min}$ at $4{ }^{\circ} \mathrm{C}$. Pellet was resuspended in $1 \mathrm{I}$ of ice cold water and centrifuged as described above. This washing was repeated one more time. Pellet was resuspended in $20 \mathrm{ml}$ ice cold sterile $10 \%$ glycerol and centrifuged at $6000 \mathrm{rpm}$ for $15 \mathrm{~min}$ at $4{ }^{\circ} \mathrm{C}$. Pellet was resuspended in $2 \mathrm{ml}$ ice cold, $10 \%$ glycerol, aliquots of $40 \mu \mathrm{l}$ were stored at $-80^{\circ} \mathrm{C}$.

\section{Transformation of the electrocompetent E.coli}

SOC medium

\author{
$0.5 \%$ Yeast extract \\ $2 \%$ Bacto-tryptone \\ $10 \mathrm{mM}$ Sodium chloride \\ $2.5 \mathrm{mM}$ Potassium chloride \\ $10 \mathrm{mM}$ Magnesium chloride
}

For each electroporation $40 \mu \mathrm{l}$ of the electrocompetent cells were used. $0.5 \mu \mathrm{g}$ of DNA was added to the cells and the contents were transferred into a pre-chilled, sterile electroporation cuvette. The cuvette was placed in the electroporater and pulse was given. SOC medium was added to the cells and they were allowed to recover in sterile tubes for $30 \mathrm{~min}$ at $37^{\circ} \mathrm{C}$ in a shaker incubator. Cells were plated on LB plates containing appropriate antibiotic and incubated overnight at $37^{\circ} \mathrm{C}$.

\section{Glycerol stocks of bacterial strains}

Bacterial cultures were grown overnight at $37^{\circ} \mathrm{C}$ in a shaking incubator. $0.3 \mathrm{ml}$ of sterile $100 \%$ glycerol was taken in freezing vials to which $700 \mu \mathrm{l}$ of the overnight culture was added. The contents were gently mixed and stored at $-80^{\circ} \mathrm{C}$. 


\section{Mini preparation of plasmid DNA from E.coli}

Plasmid DNA was isolated from E.coli cultures using the kit provided by Qiagen. Isolation was done as follows according to the instructions of the manufacturer.

Buffer P1 $\quad 50 \mathrm{mM}$ Tris/ $\mathrm{HCl} \mathrm{pH} 8.0$

$10 \mathrm{mM}$ EDTA

$100 \mu \mathrm{g} / \mathrm{ml}$ RNase A

Buffer P2 $\quad 0.2 \mathrm{M} \mathrm{NaOH}$

$1 \%$ SDS

Buffer N3 $3 \mathrm{M}$ Potassium acetate $\mathrm{pH} 5.5$

A single E.coli colony was inoculated into $2 \mathrm{ml}$ of LB medium containing $100 \mu \mathrm{g} / \mathrm{ml}$ of antibiotic and grown overnight at $37^{\circ} \mathrm{C}$ in a shaking incubator. Cells were pelleted in a table-top centrifuge at 10,000 rpm for $10 \mathrm{~min}$. Cell pellet was resuspended in buffer P1 $(250 \mu \mathrm{l})$ and buffer P2 $(250 \mu \mathrm{l})$ was added, mixed gently by inverting the tube 3-4 times. To this, buffer N3 (350 $\mu$ ) was added gently, mixed and centrifuged for $10 \mathrm{~min}$ at $13000 \mathrm{rpm}$ in a table-top eppendorf centrifuge. The supernatant was applied onto a QIAprep spin column and centrifuged for $1 \mathrm{~min}$ at $13000 \mathrm{rpm}$. Flow through was discarded, the column was washed with buffer PE $(0.75 \mu \mathrm{l})$ and centrifuged again for $1 \mathrm{~min}$. Flow through was discarded and the column was centrifuged for an additional $1 \mathrm{~min}$ to remove any residual wash buffer. The column was placed in a clean eppendorf tube and $50 \mu \mathrm{l}$ of sterile water was added directly to the centre of the column. The column was let to stand for 1 min and DNA was eluted by centrifuging at $13000 \mathrm{rpm}$ for $1 \mathrm{~min}$.

\section{Midi preparation of plasmid DNA from E.coli}

Composition of buffer P1, P2 and P3 used in this preparation are same as described for mini DNA preparation.

QBT $\quad 750 \mathrm{mM}$ Sodium chloride

$50 \mathrm{mM}$ MOPS pH 7.0

$15 \%$ Ethanol

$0.5 \%$ Triton $\mathrm{X}-100$ 
QC: $\quad 1 \mathrm{mM}$ Sodium chloride

$50 \mathrm{mM}$ MOPS pH 7.0

$15 \%$ Ethanol

QF:

1.25 M Sodium chloride

$50 \mathrm{mM}$ Tris/HCl pH

$15 \%$ Ethanol

E. coli was inoculated into $50 \mathrm{ml}$ LB media containing $100 \mu \mathrm{g} / \mathrm{ml}$ ampicillin. The culture was grown at $37^{\circ} \mathrm{C}$ overnight, in a shaking incubator. Cells were pelleted in a Beckman JA10 rotor at $6000 \mathrm{rpm}$ for $15 \mathrm{~min}$. Pellet was resuspended in $6 \mathrm{ml}$ of buffer P1. $6 \mathrm{ml}$ of buffer P2 was added and gently mixed. This was incubated at room temperature for $5 \mathrm{~min}$. During the period of incubation, the QIA filter cartridge was prepared, $6 \mathrm{ml}$ of buffer P3 (prechilled) was added, mixed gently, and the lysate was poured into the barrel of the QIAfilter cartrigde and incubated for $10 \mathrm{~min}$. A HiSpeed Midi Tip was equilibrated by applying $4 \mathrm{ml}$ of buffer QBT and the column was allowed to empty by gravity flow. Plunger was gently inserted into the cartridge and the cell lysate was filtered into the equilibrated HiSpeed Tip. The tip was washed with $20 \mathrm{ml}$ of buffer QC. DNA was eluted with $5 \mathrm{ml}$ of buffer QF. Eluted DNA was precipitated by adding $3.5 \mathrm{ml}$ of isopropanol. QIAprecipitator was attached to the 20 $\mathrm{ml}$ syringe and the DNA was filtered through the precipitator using constant pressure. The precipitator was then attached to $5 \mathrm{ml}$ syringe and $1 \mathrm{ml}$ of sterile water was added. DNA was eluted into a new collecting tube. This step was repeated again with the same eluate to get higher concentration of DNA. 


\subsubsection{Protocols for yeast}

Transformation of yeast cells- Chemical Method

$10 \times$ TE buffer

$10 \times$ LiOAC

Salmon sperm DNA

$10 \mathrm{mg} / \mathrm{ml}$
$0.1 \mathrm{M} \mathrm{Tris} / \mathrm{HCl}$

0.01 M EDTA, pH 7.5

$1 \mathrm{M}$ Lithium acetate, $\mathrm{pH} 7.5$

( $\mathrm{pH}$ was adjusted using dilute acetic acid)

Dissolved in water.Sonicated and denatured for $5 \mathrm{~min}$ at $95^{\circ} \mathrm{C}$.

Chilled on ice.

Cells were grown in YPD media to an OD $600=0.6-1.2$ and pelleted at 3000 rpm for 5 min at $4^{\circ} \mathrm{C}$. Cells were washed four times in sterile water.

Cell pellet from a $200 \mathrm{ml}$ culture was resuspended in $1.5 \mathrm{ml} \mathrm{LiOAc/TE}$ (1x) and incubated on ice for 2 hours. To $100 \mu$ of the competent cells $1-5 \mu \mathrm{g}$ of plasmid DNA and $100 \mu \mathrm{g}$ of salmon sperm DNA was added and incubated at $30{ }^{\circ} \mathrm{C}$ for $30 \mathrm{~min} .1 .2$ $\mathrm{ml}$ of $40 \%$ PEG 4000 in 1x LiOAc/TE was added to each of the tubes and carefully mixed by pipetting. Cells were incubated at $30{ }^{\circ} \mathrm{C}$ for 30 min with intermittent mixing. Cells were heat shocked at $42{ }^{\circ} \mathrm{C}$ for $5 \mathrm{~min}$ and then allowed to cool on ice. Cells were pelleted by centrifugation at $6500 \mathrm{rpm}$ for $30 \mathrm{sec}$. The cell pellet was resuspended in $1 \mathrm{ml}$ of $1 \mathrm{x}$ TE buffer. $0.2 \mathrm{ml}$ of cells were spread over the selection plate and incubated at $30{ }^{\circ} \mathrm{C}$ for $3-4$ days.

\section{Glycerol stocks of yeast cells}

Yeast cells were spread onto YPD plates and the cells were allowed to grow at 30 ${ }^{\circ} \mathrm{C} .3 \mathrm{ml}$ of sterile $15 \%$ glycerol was taken in a vial. Half of the lawn of cells on the 
plate were scraped of using a small sterile spatula and resuspended into the glycerol. The vials were then placed directly at $-70{ }^{\circ} \mathrm{C}$.

Isolation of genomic DNA from Yeast

Spheroplasting buffer

1.2 M Sorbitol

50 mM Tris/HCl pH 7.5

10 mM EDTA

$10 \mathrm{mM}$ DTT

$0.5 \mathrm{mg} / \mathrm{ml}$ Zymolyase

Lysis Buffer

$2 \%$ SDS

$0.1 \mathrm{M}$ Tris/HCL pH 8.0

10 mM EDTA pH 8.0

A $200 \mathrm{ml}$ of liquid stationary culture of Yeast in YPD was used for the isolation of genomic DNA. Cells were pelleted down and washed with water. Pellet was resuspended in $8 \mathrm{ml}$ Spheroplasting buffer in JA-20 tube and incubated for 30-40 min at $37{ }^{\circ} \mathrm{C}$ and was mixed time to time. $10 \mathrm{ml}$ of Lysis buffer was added, vortexed shortly and kept at $65^{\circ} \mathrm{C}$ for $5-10 \mathrm{~min} .10 \mathrm{ml}$ of $5 \mathrm{M}$ Potassium acetate was added and centrifuged for $15 \mathrm{~min}$ at $12000 \mathrm{rpm}$ at $4{ }^{\circ} \mathrm{C}$. Supernatant was collected into a new JA-20 tube and the pellet was discarded. $200 \mu \mathrm{l}$ of Ammonium acetate per 300 $\mu \mathrm{l}$ of supernatant and $1 \mu \mathrm{l}$ of isopropanol (cold) per $300 \mu \mathrm{l}$ of supernatant was added. This was incubated overnight at $-20^{\circ} \mathrm{C}$.

Next day, the experiment was continued by centrifuging at $12000 \mathrm{rpm}$ at 4 ${ }^{\circ} \mathrm{C}$.

Pellet was washed with $70 \%$ Ethanol (cold) and dried at $37{ }^{\circ} \mathrm{C}$. Pellet was resuspended in $15 \mathrm{ml}$ TE buffer and incubated together with $150 \mu \mathrm{l}$ RNase (10 $\mathrm{mg} / \mathrm{ml}$ ) for 1 hour at $37^{\circ} \mathrm{C} .300 \mu \mathrm{l}$ of $5 \mathrm{M} \mathrm{NaCl}, 150 \mu \mathrm{l}$ of Pronase $(20 \mathrm{mg} / \mathrm{ml})$ was added and incubated for $30 \mathrm{~min}$ at $37^{\circ} \mathrm{C}$. DNA was extracted with cold Phenol (twice in 1:1) and with Chloroform at $13000 \mathrm{rpm}$ for $5 \mathrm{~min}$. DNA was precipitated as described in the later section. 


\title{
Isolation of plasmid DNA from Yeast
}

Lysis Buffer

\author{
$1 \%$ SDS \\ $10 \mathrm{mM}$ Tris/HCL pH 8.0 \\ $1 \mathrm{mM}$ EDTA pH 8.0 \\ $100 \mathrm{mM} \mathrm{NaCl}$ \\ $2 \%$ Triton $\times 100$
}

$2 \mathrm{ml}$ liquid culture of Yeast in SD medium was used for the isolation of plasmid DNA.

Cells were taken in a microcentrifuge tube and centrifuged for $30 \mathrm{sec}$ at $13000 \mathrm{rpm}$.

Pellet was resuspended in $200 \mathrm{ml}$ of Lysis buffer. $100 \mathrm{ml}$ of glass beads and $200 \mathrm{ml}$ of Phenol-Chloroform was added to remove the proteins. This was vortexed for $2 \mathrm{~min}$ and centrifuged for $5 \mathrm{~min}$ at $13000 \mathrm{rpm}$ at $4{ }^{\circ} \mathrm{C}$. The upper phase was carefully transferred into a new microfuge tube without taking any phenol. To this, $20 \mathrm{ml}$ of 3 M Sodium acetate $\mathrm{pH} 5.2$ and $100 \%$ of Ethanol was added and centrifuged for 10 min at $13000 \mathrm{rpm}$ at $4{ }^{\circ} \mathrm{C}$. The pellet was washed with $70 \%$ Ehanol (cold) and centrifuged again for $1 \mathrm{~min}$. Pellet was dried at $37^{\circ} \mathrm{C}$. DNA pellet was resuspended in sterile water.

\section{Mating and Sporulation}

Yeast can exist stably in either haploid or diploid states. A haploid can be of two mating types, either MAT $\alpha$ or MATa. The result of mating is a diploid cell $\alpha / a$ which is formed by the fusion of an $\alpha$ cells and an a cell. A diploid cell grows indefinetly, but under starving conditions, it undergoes meiosis forming 4 haploid spores enclosed in a structure called ascus. Meiosis is induced by shifting cells to a medium without nitrogen source with acetate as the sole carbon source.

MAT $\alpha$ and MATa were mated on YPD plate by streaking few cells of each strain. Mating was observed after 6 hrs under the microscope. Diploid cells were streaked on YPD plates. To achieve sporulation, diploid cells were grown in presporulation media for 2 days at $30^{\circ} \mathrm{C}$. Cells were harvested and washed with water (2X). Cells were spread on acetate plates and incubated at $30{ }^{\circ} \mathrm{C}$ for 3 days. Cells form a thick layer. Cells were scraped out and collected in Tween 80 water. 
Cells were vigourously vortexed for $30 \mathrm{sec}$ with glass beads and paraffin oil and centrifuged at $200 \mathrm{xg}$ for $5 \mathrm{~min}(3 \mathrm{x})$. Cells were spread with $15 \%$ gelatin on selection plates.

\subsubsection{Protocols for DNA / RNA}

\section{Precipitation of DNA with ethanol}

Two volumes of $100 \%$ ethanol was added to the DNA. This was incubated at $-70{ }^{\circ} \mathrm{C}$ for $20 \mathrm{~min}$ or $10 \mathrm{~min}$ on dry ice or overnight at $-20{ }^{\circ} \mathrm{C}$. DNA was pelleted at 13000 rpm for $10 \mathrm{~min}$. The pellet was washed with $70 \%$ ethanol and pelleted by centrifuging for $5 \mathrm{~min}$ at $13000 \mathrm{rpm}$. The DNA pellet was dried at $37^{\circ} \mathrm{C}$ and was resuspended in sterile water.

\section{Determining the concentration of DNA}

DNA concentration was determined using a spectrophotometer at $260 \mathrm{~nm}$. DNA was diluted in water and the absorbance was measured at $260 \mathrm{~nm}$.

Absorbance or optical density (OD) of 1 at $260 \mathrm{~nm}$ corresponds to $\sim 50 \mu \mathrm{g} / \mathrm{ml}$ of double stranded DNA or $\sim 40 \mu \mathrm{g} / \mathrm{ml}$ of single stranded DNA and RNA or $\sim 20 \mu \mathrm{g} / \mathrm{ml}$ of oligonucleotides. The ratio of the readings at $260 \mathrm{~nm}$ and $280 \mathrm{~nm}\left(\mathrm{OD}_{260} / \mathrm{OD}_{280}\right)$ provides an estimate of the purity of the nucleic acid. Pure preparations of DNA and RNA have $\mathrm{OD}_{260} / \mathrm{OD}_{280}$ values of 1.8 and 2.0, respectively. Any contamination with proteins or phenol would yield values less than mentioned above.

\section{Restriction endonuclease digestion of DNA}

The activity of restriction enzyme is measured in Units $(U)$.

One unit of restriction enzyme is the amount of enzyme required to completely digest $1 \mu \mathrm{g}$ substrate DNA in $1 \mathrm{~h}$.

Plasmid DNA

$0.5-1 \mu \mathrm{g}$

$10 \times$ buffer

$2 \mu \mathrm{l}$

Restriction enzyme

BSA

\section{1-2 U}

$1 \mu \mathrm{g} / \mu \mathrm{l}$ (added where essential) 
Water was added to a final volume of $20 \mu \mathrm{l}$. Reaction mix was incubated at $37^{\circ} \mathrm{C}$ for 2 hours.

*Incubation temperatures were set as recommended by the manufacturer (New England Bio Labs Beverly U.S.A.) which varies from enzyme to enzyme. Reaction mix was analyzed on an agarose gel ( 0.8 to $2 \%$ depending on the size of the DNA of interest)

The buffers and enzymes used were all from New England Biolabs.

The composition of the buffers is as follows:

NEB 1: $10 \mathrm{mM}$ Bis Tris Propane/HCl (pH 7.0), $10 \mathrm{mM} \mathrm{MgCl} 2,1 \mathrm{mM}$ DTT

NEB 2: $10 \mathrm{mM}$ Tris/HCl (pH 7.9), $10 \mathrm{mM} \mathrm{MgCl}_{2}, 50 \mathrm{mM} \mathrm{NaCl}, 1 \mathrm{mM}$ DTT

NEB 3: $50 \mathrm{mM}$ Tris/HCl (pH 7.9), $10 \mathrm{mM} \mathrm{MgCl}$, $100 \mathrm{mM} \mathrm{NaCl,} 1 \mathrm{mM}$ DTT

NEB 4: 20 mM Tris/acetate (pH 7.9), 10 mM Magnesium acetate, 1 mM DTT, 50 mM Potassium acetate

\section{Agarose gel electrophoresis of DNA}

The size and purity of DNA is analyzed by agarose gel electrophoresis. Concentration of agarose used for analysis is inversely proportional to the size of the DNA of interest, that is, the larger the DNA, the lower is the concentration of agarose.

\begin{tabular}{|c|c|}
\hline Agarose concentration (\%) & DNA size $(\mathrm{kb})$ \\
\hline 0.7 & $20-1$ \\
\hline 0.9 & $7-0.5$ \\
\hline 1.2 & $6-0.4$ \\
\hline 1.5 & $4-0.2$ \\
\hline 2.0 & $3-0.1$ \\
\hline
\end{tabular}




\section{Gel loading buffer (10x)}

$0.25 \%(w / v)$ Bromophenol blue

$40 \%$ Saccharose in $1 \times$ TAE

Agarose was weighed and dissolved in 1X TAE by boiling in microwave oven. The agarose solution was allowed to cool till about $60{ }^{\circ} \mathrm{C}$ and ethidium bromide was added to a final concentration of $0.5 \mu \mathrm{g} / \mathrm{ml}$. This was poured into the agarose gel cassette and allowed to polymerize completely. The sample DNA was mixed with gel loading buffer and loaded into the lane. The gel electrophoresis was carried out at $100 \mathrm{~V}$. Ethidium bromide is a fluorescent dye which contains a planar group that intercalates between the stacked bases of the DNA. The fixed position of this group and its close proximity to the bases causes the dye to bind to the DNA to display an increased fluorescent yield compared to that of the dye in free solution. Ultraviolet radiation at $254 \mathrm{~nm}$ is absorbed by the DNA and transmitted to the dye; radiation at $302 \mathrm{~nm}$ and $366 \mathrm{~nm}$ is absorbed by the bound dye itself. In both cases, the energy is re-emitted at $590 \mathrm{~nm}$ in the red orange region of the visible spectrum. Hence DNA can be visualized under a UV transilluminator. The gel was photographed using a gel documentation system.

\section{Cloning and DNA ligation}

DNA ligase links fragments of DNA, containing blunt end or cohesive-end termini, to each other in a covalent manner. It catalyses the formation of a phosphodiester bond between juxtaposed 5' phosphate and 3' hydroxyl termini in duplex DNA.

A plasmid vector DNA and desired fragment DNA was digested with appropriate restriction endonucleases. Both the vector and the desired fragment were purified from agarose gel using Quiagen gel extraction kit. Ligation was performed using T4-DNA Ligase. Ligation mixture was incubated at $16{ }^{\circ} \mathrm{C}$ overnight and then used for E.coli transformation.

Ligation Mixture $(10 \mu \mathrm{l})$

Vector

Desired fragment

T4 DNA ligase buffer (10X)
$10-20 \mathrm{ng}$

3 times the vector concentration

$1 \mu \mathrm{l}$ 
T4 DNA ligase

$1 \mu \mathrm{l}$

\section{Phophatase treatment of digested plasmid DNA}

To prevent the religation of plasmids that were digested with single restriction endonuclease, they were treated with alkaline phosphates to remove the 5' phosphate from the digested plasmid. To the digested plasmid, in a reaction volume of $50 \mu \mathrm{l}, 2 \mu \mathrm{l}$ of alkaline phosphatase (Boehringer) was added (if digestion was done in NEB buffer $1.5 \mu$ of $10 x$ NEB buffer N3 was added) and the reaction mix was incubated for $1 \mathrm{~h}$ at $37^{\circ} \mathrm{C}$. Reaction was stopped by the addition of $0.5 \mu$ of $5 \mathrm{mM}$ EDTA, followed by heating at $75^{\circ} \mathrm{C}$ for $20 \mathrm{~min}$. Plasmid was purified from agarose gel using Quigen gel extraction kit.

\section{Polymerase Chain Reaction (PCR)}

PCR is a rapid method for enzymatic amplification of specific DNA fragments.

It includes 3 steps, which are necessary for DNA amplification.

1. Template DNA denaturation to get single stranded DNA.

2. Annealing (binding of oligonucleotide primer to single strands).

3. Extension (synthesis of DNA, strating from bound primers).

Example:

1. $95^{\circ} \mathrm{C} \quad 30 \mathrm{sec}$

2. $50^{\circ} \mathrm{C} \quad 30 \mathrm{sec}\left(\mathrm{T}_{\mathrm{m}}\right.$ of primers)

3. $72{ }^{\circ} \mathrm{C} \quad 1 \mathrm{~min}$ (Length of the template)

30 Cycles

PCR Mix

10X Taq buffer (100 mM Tris/HCl pH 9.0; 500 mM KCl) $5 \mu \mathrm{l}$

$2.5 \mathrm{mM}$ dNTPs (Amersham, Stock $100 \mathrm{mM}$ ) $1 \mu \mathrm{l}$

Oligonucleotide primer $1(5 \mathrm{pmol} / \mathrm{ml}) \quad 4 \mu \mathrm{l}$

Oligonucleotide primer $2(5 \mathrm{pmol} / \mathrm{ml}) \quad 4 \mu \mathrm{l}$

Template DNA 500 ng

Taq polymerase $\quad 1 \mu \mathrm{l}$

Final volume made upto $50 \mu \mathrm{l}$ 
DNA Sequencing PCR:

Sequencing premix

Primer

DNA template

Final volume made upto $10 \mu \mathrm{l}$.

Seuqncing PCR:

$96{ }^{\circ} \mathrm{C}$

$50{ }^{\circ} \mathrm{C}$

$60{ }^{\circ} \mathrm{C}$

30 cycles

Sequencing products were precipitated at room temperature by addition of $1 / 5 \mathrm{vol}$ of $3 \mathrm{M} \mathrm{NaOAc} \mathrm{pH} 5.2$ and 5 vol of 95\% ethanol, vortexing and incubating for $10 \mathrm{~min}$. DNA was pelleted by centrifugation at full speed for $20 \mathrm{~min}$, washed once with $70 \%$ ethanol, dried and resuspended in 25-50 $\mu \mathrm{HPLC}-\mathrm{H}_{2} \mathrm{O}$.

\section{Site directed mutagenesis}

Site directed mutagenesis is used to make point mutations, delete or insert single or multiple amino acids and introduction of restriction sites into cloned DNA of interest. This is a specialized PCR protocol. Pair of PCR primers were designed to amplify plasmid completely so that both at $5^{\prime}$ end and complementary 3 'end, a mutation is introduced.

PCR is done as described in the preovious section. PCR product is treated with Dpnl. The Dpnl endonuclease is specific for methylated and hemimethylated DNA and is used to digest the parental DNA template and to select for mutation containing synthesized DNA. $1 \mu \mathrm{l}$ of Dpnl was added to the PCR product and incubated for 2 hours at $37^{\circ} \mathrm{C}$ which was then used for transformation in E.coli.

RNA Analysis

\section{Isolation of total yeast RNA using RNAeasy kit}

Total yeast RNA was extracted using RNAeasy kit from Quiagen. Before and during RNA extraction RNase-free environment was maintained by wearing gloves while handling reagents and RNA samples to prevent RNase contamination. Plasticware, 
glassware and electrophoresis tank were treated to inactivate RNases with $0.1 \mathrm{M}$ $\mathrm{NaOH}$ (overnight) followed by RNase-free water. RNase-free water was obtained by treating deionized water with $0.1 \%$ DEPC and autoclaving. All solutions were prepared using DEPC water.

Buffer $\mathrm{Y} 1$

1 M Sorbitol

0.1 M EDTA pH 7.4

Before use, $0.1 \% \beta-M E$ and $50 \cup$ Zymolyase was added per $\mathrm{ml}$ of buffer $\mathrm{Y} 1$

\section{Buffer RPE}

\section{BufferRLT}

Before use, $10 \mu$ of $\beta$-ME per ml of buffer RLT was added.

Total yeast RNA isolation was done using 40 OD cells in early logarithmic phase.

All steps and centrifugations were done at RT.

Yeast cells were harvested by centrifuging at $500 \mathrm{~g}$ for $5 \mathrm{~min}$ at $4{ }^{\circ} \mathrm{C}$. Cell pellet was resuspended in freshly prepared buffer $Y 1$ containing zymolyase and incubated at for $30 \mathrm{~min}$ at $30{ }^{\circ} \mathrm{C}$ to generate spheroplasts. $1 \mathrm{ml}$ of buffer $\mathrm{Y} 1$ was used for per $10^{8}$ yeast cells. Centrifugation was done for $5 \mathrm{~min}$ at $500 \mathrm{~g}$ to pellet spheroplasts and supernatant was discarded. Spheroplasts were disrupted by adding $2 \mathrm{ml}$ of buffer RLT. Cells were homogenized by passing the lysate at least 5-10 times through a 20 gauge needle fitted to an RNase-free syringe. Cell lysate was centrifuged for $5 \mathrm{~min}$ at $3000 \mathrm{~g}$. Supernatant was transferred into a new $15 \mathrm{ml}$ tube by pipetting and this was used for further steps. 1 volume $(4 \mathrm{ml})$ of $70 \%$ ethanol was added to the homopgenized lysate and was thoroughly mixed by shaking vigourously. Sample was applied to an RNeasy column placed in a $15 \mathrm{ml}$ tube and centrifuged for $5 \mathrm{~min}$ at $3000 \mathrm{~g} .4 \mathrm{ml}$ of buffer RW1 was added to the column and centrifuged again to wash the column. Flow through was discarded at each step. $2.5 \mathrm{ml}$ of buffer RPE was added and centrifuged for $2 \mathrm{~min}$ at $3000 \mathrm{~g}$. This step was repeated again to dry the RNeasy silica gel-membrane. RNeasy column was transferred into a new collection tube and RNA was eluted with $250 \mu$ of RNase-free water by centrifuging for 3 min at $3000 \mathrm{~g}$. To obtain a higher yield, the elution step was repeated using the first eluate. 


\section{Northen Blot}

All instruments, containers and work place used were cleaned extensively in advance to prevent RNase contamination, as described in Quiagen RNeasy Kit manual. 10X MOPS buffer $200 \mathrm{mM}$ MOPS, $50 \mathrm{mM}$ NaOAC, $10 \mathrm{mM}$ EDTA, pH 7.0

1X MOPS running gel buffer $1 \times$ MOPS buffer. $0.74 \%$ formaldehyde (FA)

5X RNA loading dye 4 mM EDTA, pH 8.0, 2.7\% FA, 20\% glycerol, 31\% formamide, 4x MOPS buffer, bromophenol blue

20X SSC buffer $3 \mathrm{M} \mathrm{NaCl}, 0.34 \mathrm{M} \mathrm{Na}-$ Citrate, $\mathrm{pH} 7.0$

Salmon sperm DNA (SSP) $10 \mathrm{mg} / \mathrm{ml}$

TE buffer $10 \mathrm{mM}$ Tris/HCL, pH 7.5, 1mM EDTA

$\alpha-{ }^{32} P-d C T P$ $5 \mu \mathrm{Ci} / \mu \mathrm{l}$

\section{Agarose gel electrophoresis of RNA}

Agarose gel buffer

$\begin{array}{ll}\text { MOPS (10X) } & 15 \mathrm{ml} \\ \text { DEPC water } & 150 \mathrm{ml} \\ \text { Agarose } & 1.2 \%\end{array}$

Electrophoresis buffer (MOPS 1X)

$\begin{array}{ll}\text { MOPS } & 200 \mathrm{mM} \\ \text { Sodium acetate } & 50 \mathrm{mM} \\ \text { EDTA } & 10 \mathrm{mM}\end{array}$

10X stock solution was made in DEPC water and $\mathrm{pH}$ was adjusted using $\mathrm{NaOH}$.

Gel loading buffer

Bromophenol blue $1 \mathrm{X}$

DEPC water $4 \mathrm{X}$

Formamide $4 \mathrm{X}$

Formaldehyde 2X

MOPS 10X 2X 
Solutions were prepared according to the Qiagen RNeasy Kit Manual. For the agarose gel, agarose was boiled in 1x MOPS buffer and left to cool until about $50{ }^{\circ} \mathrm{C}$. Formaldehyde to a concentration of $0.7 \%$ and ethdium bromide was added before pouring the gel. RNA samples were mixed with $5 x$ dye, indubated at $65^{\circ} \mathrm{C}$ for 5 min and kept on ice briefly before loading. The gel was run at 30-40 mA from 4-7 h. To prepare for the transfer, the gel was briefly washed with water and equilibrated in $20 \mathrm{x}$ SSC buffer.

RNA transfer to nylon membrane: After cutting the gel to the required size using a scale and taking a picture including the scale, the gel is transferred back in the $20 \mathrm{x}$ SSC. For overnight transfer of RNA to the nylon membrane the setup is as follows:

After overnight transfer, the membrane was dried at room temperature, exposed to UV light for $15 \mathrm{sec}$ to crosslink the RNA to the membrane and incubated at $60{ }^{\circ} \mathrm{C}$ for $1 \mathrm{~h}$. The membrane was rolled and kept in falcon tube.

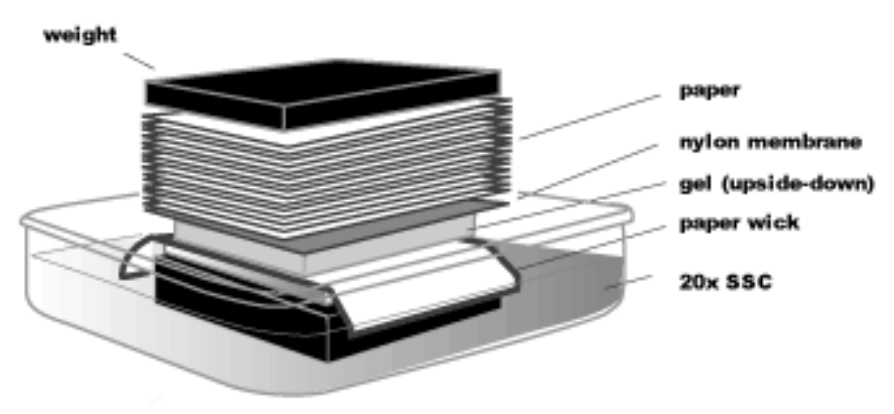

Radioactive labelling of DNA fragment: Approximately 25 ng of DNA fragment was diluted to $45 \mu \mathrm{l}$ in TE buffer. After $5 \mathrm{~min}$ at $95{ }^{\circ} \mathrm{C}$ and $5 \mathrm{~min}$ on ice, the solution was transferred to a cup containing rediprime random DNA labelling kit lyophilisate, on ice. $30-50 \mu \mathrm{Ci}$ of ${ }^{32} \mathrm{P}$-dCTP was added, depending on the calibration date of the radioactivity, and the lyophilisate was resuspended by pipetting. The labelling reaction mix was incubated at $37^{\circ} \mathrm{C}$ fro $15 \mathrm{~min}$. Qiaspin nucleotide removal kit was used to purify the labelled DNA and $1 / 100$ of the eluate was measured in a scintillation counter using Cerenkov radiation. 2-15 $\mu \mathrm{Ci}$ was used for one membrane. 
Hybridization: To prepare the membrane for hybridization, salt was removed by washing the membrane twice with water for $5 \mathrm{~min}$. Prehybridisation was done in $3 \mathrm{ml}$ Rapid-hyb hybridization buffer for at least $1 \mathrm{~h}$ at $65^{\circ} \mathrm{C}$. After labelling the probe, SSP was boiled for $10-15 \mathrm{~min} .10 \mu \mathrm{l}$ of SSP/ $\mathrm{ml}$ of hybridization buffer was added to the radioactive DNA solution, the mix was boiled was for $5 \mathrm{~min}$ and added dropwise to the hybridization buffer. The tube was double-sealed in a plastic bag and incubated overnight at $65^{\circ} \mathrm{C}$ in a rolling hybridization oven.

The membrane was washed with $0.1 \%$ SDS in $2 x$ SSC for $15 \mathrm{~min}$ at room temperature and with $0.1 \%$ SDS in $0.2 x \mathrm{SSC}$ for $15 \mathrm{~min}$ at $65{ }^{\circ} \mathrm{C}$. Further washes were done eventually after the first exposure to a phosphoimager screen, depending on the signal/background relationship.

Stripping of the membrane: The membrane was placed in boiling $0.1 \% \mathrm{SDS} / 0.2 \mathrm{x}$ SSC solution and allowed to cool. The remaining signal was detected after overnight exposure, if any was signal detected, the procedure was reapeated 3 times.

\subsubsection{BIOCHEMICAL METHODS}

\subsubsection{Analysis of proteins}

\section{Determination of protein concentration using the BIORAD reagent}

Bovine Serum Albumin (BSA) stock solution $1 \mathrm{mg} / \mathrm{ml}$

Concentration range: $5-20 \mu \mathrm{g} / \mu \mathrm{l}$

A standard curve was made using BSA in the range of $5-20 \mu \mathrm{g} .2 \mu \mathrm{l}$ of the sample was used for the protein estimation. The volume was made up to $800 \mu \mathrm{l}$ with water. $200 \mu \mathrm{l}$ of the BIORAD reagent was added and the samples were incubated for 3-5 $\mathrm{min}$ at room temperature, optical density was measured at $595 \mathrm{~nm}$ in the Spectrophotometer. 


\section{Precipitation of proteins using Trichloro acetic acid (TCA)}

Trichloroacetic acid (TCA) solution

$100 \mathrm{~g}$ of TCA crystals was weighed and the volume was made up to $100 \mathrm{ml}$ with water

$2 \%$ Sodium acetate in ethanol $2 \mathrm{~g}$ of Sodium was dissolved in small amount of water and volume was made up to $100 \mathrm{ml}$ with ethanol

The proteins were precipitated by adding TCA to a final concentration of $10 \%$ and incubated on ice in the cold room overnight. The precipitated samples were centrifuged at $13000 \mathrm{rpm}$, for $10 \mathrm{~min}$ at $4{ }^{\circ} \mathrm{C}$. The supernatant was discarded and the pellets were washed $500 \mu \mathrm{l}$ of $2 \%$ sodium acetate solution in ethanol. The samples were again centrifuged as above, supernatant was discarded and the pellets were air-dried for 10-15 min at RT. The pellets were resuspended in 1x SDS-PAGE buffer, boiled and loaded on SDS-PAGE for further analysis.

\section{Solubilisation of proteins}

$2 \times$ Laemmli buffer

$125 \mathrm{mM}$ Tris/ $\mathrm{HCl}, \mathrm{pH} 6.8$

$4 \%$ SDS

$0.004 \%$ Bromophenol blue

$20 \%(w / v)$ Glycerol

$20 \mathrm{mM}$ DTT

Proteins were resuspended in $1 \mathrm{x}$ Laemmli buffer. The resuspended proteins were boiled at $95{ }^{\circ} \mathrm{C}$ for $5 \mathrm{~min}$, cooled on ice for $1 \mathrm{~min}$, centrifuged at $13000 \mathrm{rpm}$ for $2 \mathrm{~min}$ and resolved by SDS-PAGE.

\section{Gel Electrophoresis}

Gel running buffers

Anode buffer $(5 \mathrm{x}) \quad 50 \mathrm{mM}$ Tris

192 mM Glycine

Volume was made up with double distilled water.

Cathode buffer $(1 \mathrm{x})$

$0.1 \%$ SDS in anode buffer

Volume was made up with double distilled water.

Separating gel buffer (4x) $1.5 \mathrm{M}$ Tris/HCl pH 8.8 


\section{$0.4 \%$ SDS \\ $0.4 \%$ APS}

Volume was made up with double distilled water.

Stacking gel buffer (4x) $\quad 0.5 \mathrm{M}$ Tris/ $\mathrm{HCl}$ pH 6.8

$0.4 \%(w / v)$ SDS

Acrylamide Solution

$30 \%(w / v)$ Acrylamide

$0.8 \%(\mathrm{w} / \mathrm{v})$ Bisacrylamide

Ammonium per sulphate $10 \%(\mathrm{w} / \mathrm{v})$

Recrystallised ammonium peroxidisulphate (APS) was dissolved in double distilled water. This was prepared fresh every week.

Preparation of acrylamide solution for SDS-PAGE: (for one minigel-8 ml)

All volumes are in $\mathrm{ml}$ unless indicated otherwise.

\begin{tabular}{|l|l|l|l|l|l|}
\hline Gel (\%) & 5 & 10 & 12.5 & 15 & $\begin{array}{l}3 \mathrm{ml} \text { Stacking } \\
\text { Gel }(4.5 \%)\end{array}$ \\
\hline $\begin{array}{l}\text { Acrylamide/ } \\
\text { Bis-acrylamide }\end{array}$ & 1.33 & 2.67 & 3.3 & 4 & 0.45 \\
\hline $\begin{array}{l}4 \text { x resolving gel } \\
\text { buffer }\end{array}$ & 2 & 2 & 2 & 2 & $\begin{array}{l}4 \text { x stacking } \\
\text { gel buffer } \\
0.45\end{array}$ \\
\hline Water & 4.58 & 3.2 & 2.6 & 1.9 & 1.77 \\
\hline Temed & $8 \mu \mathrm{l}$ & $8 \mu \mathrm{l}$ & $8 \mu \mathrm{l}$ & $8 \mu \mathrm{l}$ & $3 \mu \mathrm{l}$ \\
\hline $10 \%$ APS & $80 \mu \mathrm{l}$ & $80 \mu \mathrm{l}$ & $80 \mu \mathrm{l}$ & $80 \mu \mathrm{l}$ & $30 \mu \mathrm{l}$ \\
\hline
\end{tabular}

SDS-PAGE is a biochemical technique where proteins are separated based on their molecular weight. The gel is discontinuous; it has a stacking gel which is present on top of the resolving gel. SDS-PAGE can be used to separate proteins based on their native size (native SDS-PAGE) or their subunit size (reducing SDS-PAGE). Two clean glass plates were fixed together with a spacer of appropriate thickness $(0.75-$ $1.5 \mathrm{mM}$ ) using holders or clips. The resolving gel was poured and isobutanol was layered on top of it. The gel was allowed to polymerize for about $30 \mathrm{~min}$ and isobutanol was thoroughly washed off using double distilled water. The stacking gel 
was poured on top of the resolving gel and a comb, of appropriate size and appropriate number of wells, was placed in the stacking gel and left undisturbed for about 30 min. After polymerisation of the stacking gel, the combs were removed and the wells were cleaned with double distilled water to wash off any unpolymerized acrylamide. Boiled and denatured protein samples were loaded into the wells, the gel was placed in a tank with electrophoresis buffer and run at $100-125 \mathrm{~V}$ for $2 \mathrm{~h}$.

\section{Staining of Polyacrylamide gels}

1. Coomassie blue staining

Coomassie blue stain

Destaining solution
$0.5 \%(w / v)$ Coomassie blue

$$
50 \%(\mathrm{v} / \mathrm{v}) \text { Methanol }
$$

$10 \%(v / v)$ Acetic acid in double distilled water $50 \%$ Methanol and $10 \%$ glacial acetic acid dissolved in double distilled water.

The gel was stained in Coomassie blue solution at RT for 1-2 hours and destained using the destaining solution overnight. After complete destaining the gel was washed with double distilled water for $15 \mathrm{~min}$ and then dried in a gel drier.

\section{Silver Staining}

Fixative

$30 \%$ Ethanol

$10 \%$ Acetic acid

Sodium thiosulphate solution

$$
\begin{aligned}
& 0.5 \text { M Sodium acetate } \\
& 30 \% \text { Ethanol } \\
& 0.5 \% \text { Glutaraldehyde } \\
& 0.2 \% \text { Sodium thiosulphate }
\end{aligned}
$$

Silver nitrate stain

$0.1 \%$ Silver nitrate 
$0.02 \%$ Formaldehyde (37\%)

Developer

$2.5 \%$ Sodium carbonate

$0.01 \%$ Formaldehyde (37\%)

Stop solution

0.05 M Glycine

All the solutions were made in double distilled water with final volume of $250 \mathrm{ml}$. for one gel.

The gel was first incubated in Fixative for $90 \mathrm{~min}$ at RT and then in Sodium thiosulphate solution for 1 hour at RT or overnight at $4{ }^{\circ} \mathrm{C}$. After 3 washes with dd water for 15 min each, the gel was stained with Siver nitrate solution for 1hour at RT and washed with water for $2 \mathrm{~min}$. The gel was washed for $1 \mathrm{~min}$ with half of the Developer which was then discarded, and again washed for 1-4 min with rest of the solution. Developing was stopped with Stop solution.

\subsubsection{Western blot analysis (semi dry method)}

Semidry blot buffers

Cathode buffer $\quad 40 \mathrm{mM} \varepsilon$-Ammonium caproic acid

$20 \mathrm{mM}$ Tris/ $\mathrm{HCl}$

$20 \%$ Methanol

Dissolved in water, $\mathrm{pH}$ was set to 9.0 with free Tris base and volume was made up with water.

Anode buffer $\quad 75 \mathrm{mM}$ Tris/ $\mathrm{HCl}$

$20 \%$ Methanol

Dissolved in water, $\mathrm{pH}$ set to 7.4 with $\mathrm{HCl}$ and volume made up with water.

TBS -Tween TBS containing $0.1 \%$ Tween-20

Blocking buffer TBST containing $5 \%$ milk powder

Proteins separated by SDS-PAGE were transferred onto nitrocellulose or PVDF membranes for western blot analysis by chemiluminescence. 6 sheets of whatman paper were cut according to the size of the gel. Three sheets were immersed in the semidry anode buffer and placed in the chamber. A glass pipette was rolled on it to remove any air bubbles. Then the membrane dipped in the cathode buffer was 
placed on top of it and again the air bubbles were removed. The gel was also soaked in the cathode buffer before placing on the membrane. Another three whatman paper sheets dipped in cathode buffer were placed on top of the gel. The glass pipette was again rolled on the set up to remove air bubbles. The proteins were transferred onto the membrane using current at $1 \mathrm{~mA} / \mathrm{cm}^{2}$ for $60-90 \mathrm{~min}$.

$3 \times$ whatman paper wet in

Cathode (-)

Cathode buffer

SDS-acrylamide gel

Membrane

$3 \times$ whatman paper wet in

Anode buffer

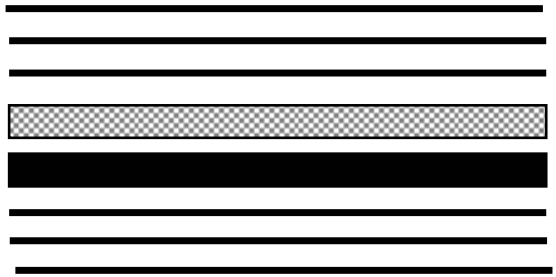

Anode (+)

After the transfer, membrane was incubated in TBST containing $5 \%$ milk powder for $1 \mathrm{~h}$ at room temperature to block all non-specific interaction sites on the membrane. After blocking, primary antibody diluted in blocking buffer at the concentrations as mentioned in 2.1.11, was added onto the membrane and incubated overnight in the cold room on a rocker. The non-specifically bound antibody was washed off by incubating the blot on a rocker with blocking buffer, changing the buffer once every 10 min for three times. The membrane was then incubated with the secondary antibody for $1 \mathrm{~h}$ at room temperature and the membrane was washed 4 times, $10 \mathrm{~min}$ each, with TBST. The proteins were detected by chemiluminescence.

\section{Detection techniques}

\section{a. Chemiluminescent Substrate from PIERCE}

Enhancer and peroxide solutions were mixed in a 1:1 ratio and incubated at room temperature for $5 \mathrm{~min}$. The substrate was washed off and signals were detected using a CCD camera or an X-ray film.

\section{b. Luminol Detection system}

Luminol

p-coumaric acid
$0.44 \mathrm{~g}$ was dissolved in $10 \mathrm{ml}$ of DMSO and aliquots were stored at $-20^{\circ} \mathrm{C}$

$0.15 \mathrm{~g}$ dissolved in $10 \mathrm{ml}$ DMSO, aliquots stored 
at $-20^{\circ} \mathrm{C}$

Solution $1(10 \mathrm{ml}) \quad 100 \mu \mathrm{l} 250 \mathrm{mM}$ Luminol

44 Hl $90 \mathrm{mM}$ p-coumaric acid

$1 \mathrm{ml} 1 \mathrm{M}$ Tris/HCl pH 8.5

$8.9 \mathrm{ml}$ Water

Solution $2(10 \mathrm{ml}) \quad 1 \mathrm{ml} 1 \mathrm{M}$ Tris/HCl pH 8.5

$6 \mu$ hydrogen peroxide (from $30 \%$ stock solution)

$9 \mathrm{ml}$ water

Solution 1 and solution 2 were mixed just before adding onto the blot.

Solutions were added onto the blot and incubated at room temperature for 1

min. The substrate was washed off and the membrane was wrapped in a polythene sheet and signals were detected using a CCD camera or an X-ray film.

\section{Stripping the antibody from the membrane}

The membrane was washed twice with water for 5 min each to wash off the chemiluminescent substrate. The membrane was stripped off the antibodies by washing with $0.2 \mathrm{~N} \mathrm{NaOH}$ for 10 min on a rocker. The membrane was again washed for 5 min with water, and 5 min with TBST, incubated in blocking buffer followed by antibody of interest for next round of chemiluminescence.

\subsubsection{Purification of GST-tagged recombinant protein}

Buffer A

Buffer B

Buffer C

Buffer D
$10 \%$ sucrose

$25 \mathrm{mM}$ Tris/HCl pH 7.5, 0.5 mM EDTA, 1mMDTT

$1 \%$ Triton $X-100$ in buffer $B$

$50 \mathrm{mM}$ Tris/HCl pH 8.0, $25 \mathrm{mM}$ glutathione, adjusted

to $\mathrm{pH} 8.0$ with $\mathrm{NaOH}$ (prepared freshly).

A bacterial clone expressing the GST-fusion protein under the control of an inducible promoter was grown in $20 \mathrm{ml}$ LB as a preculture overnight. The culture was diluted $1: 20$ in fresh LB medium and grown for $1 \mathrm{~h}$ up to an OD $600=0.5-0-8$. Protein expression was induced by adding $0.1 \mathrm{mM}$ IPTG to the culture, which was further 
grown for $3-5 \mathrm{~h}$ at $30{ }^{\circ} \mathrm{C}$. The cells were harvested at $6000 \mathrm{rpm}$ in a JA 10 rotor and washed once with cold PBS. All the following steps were performed on ice. The pellet was resuspended in $4 \mathrm{ml}$ buffer $A$, transferred to a $50 \mathrm{ml}$ falcon tube and mixed with $4 \mathrm{ml}$ buffer A containing $2 \mathrm{mg} / \mathrm{ml}$ lysozyme. After $15 \mathrm{~min}$ of incubation, the volume was made up to $20 \mathrm{ml}$ with buffer $A$. The suspension was sonicated twice for $30 \mathrm{sec}$ to reduce the viscosity of the homogenate, it was treated with $10 \mathrm{mg} / \mathrm{ml}$ RNase and 5 $\mathrm{mg} / \mathrm{ml}$ DNase for $15 \mathrm{~min}$. The lysate was finally supplemented with Triton X-100 to a concentration of $1 \%$ to increase the solubility of its components. The insoluble fraction was pelleted by centrifugation at $12000 \mathrm{rpm}$ in a JA 20 rotor and the supernatant transferred into a new tube. $260 \mu \mathrm{l}$ of glutathione-coupled sepharose beads (75\% suspension), corresponding to a bead volume of $200 \mathrm{ml}$, were centrifuged at $1000 \mathrm{rpm}$ for $5 \mathrm{~min}$ in a tabletop centrifuge and washed twice with $2 \mathrm{ml}$ of each buffer $B$ and $C$. The beads were incubated with the soluble lysate fraction on a spinning wheel at $4^{\circ} \mathrm{C}$ overnight. Next day, the sepharose was washed twice with buffer $C$ and twice with buffer B. While the buffers A-C contain DTT at pH 6-7.5 to prevent oxidization of glutathione, elution is facilitated at $\mathrm{pH} 8$ without the addition of DTT. GST-fusion protein was eluted from the beads by adding $200 \mu \mathrm{l}$ of buffer $\mathrm{D}$ and incubating the sample for $30 \mathrm{~min}$ at $4{ }^{\circ} \mathrm{C}$. Elution was repeated 4 times

\subsubsection{Protein extracts from S.cerevisiae}

\section{Spheroplasting}

Tris $/ \mathrm{SO}_{4}$ DTT buffer: $\quad 0.1 \mathrm{M}$ Tris $/ \mathrm{SO}_{4} \mathrm{pH} 9.4$ $10 \mathrm{mM}$ DTT

Spheroplasting buffer: $\quad 1.2 \mathrm{M}$ Sorbitol

$50 \mathrm{mM}$ Tris/ $\mathrm{HCl} \mathrm{pH} 7.5$

10 mM EDTA

Yeast cells are surrounded by a firm cell wall. The cell wall has to be removed before performing biochemical experiments with the cells. After the cell wall is removed the cells are called spheroplasts and the process is called spheroplasting. 
The cell pellet was resuspended in Tris/SO $\mathrm{SO}_{4}$ DTT buffer at a final concentration of 10 $\mathrm{OD}_{600} / \mathrm{ml}$ and incubated at $30^{\circ} \mathrm{C}$ for $15 \mathrm{~min}$ with slow shaking. Cells were pelleted at $3000 \mathrm{rpm}$ for $5 \mathrm{~min}$. The pellet was resuspended in spheroplasting buffer at a concentration of $6 \mathrm{OD}_{600} / \mathrm{ml}$. An aliquot of the resuspended cells was retained on ice to determine the spheroplasting (NS) efficiency. $0.5 \mathrm{mg} / 50$ OD 600 of Zymolyase 20T was added and the cells were incubated at $30{ }^{\circ} \mathrm{C}$ for 30 min with slow shaking. An aliquot of the cells after spheroplasting was also taken (S). The two samples were diluted with water and the optical density was measured at $600 \mathrm{~nm}$. The O.D. value obtained for the spheroplasted sample (S) indicates the amount of non spheroplasted cells. Using this the percentage of spheroplasting or the spheroplasting efficiency can be determined.

\section{Calculation of spheroplasting effeciency:}

O.D. of cells in spheroplasting buffer - O.D of cells after spheroplasting

Cells which are spheroplasted.

Percentage of spheroplasting obtained/ Spheroplasting efficiency

$$
=\quad \text { Cells which are spheroplasted } \quad \text { x100 }
$$

O.D. of cells in spheroplasting buffer (NS)

\section{Preparation of yeast cell lysates}

\section{a. Preparation of cell lysates using glass beads}

Glass beads: Glass beads were immersed in conc. $\mathrm{HCl}$ overnight.

The beads were then washed in distilled water till the $\mathrm{pH}$ reached 7.0. These beads were autoclaved and stored at $4{ }^{\circ} \mathrm{C}$.

Yeast cells were grown at $30^{\circ} \mathrm{C}$ in a shaker incubator in either minimal media or YPD. Cells were pelleted at $5000 \mathrm{rpm}$ for $5 \mathrm{~min}$. Cells were spheroplasted and pelleted at $2000 \mathrm{rpm}$ for $6 \mathrm{~min}$. Spheroplasts were resuspended in $700 \mu \mathrm{l}$ of $0.1 \mathrm{M}$ 
sodium phosphate buffer. To this protease inhibitor mix was added to a final concentration of $1 \mathrm{x}$. The spheroplasts were incubated in the cold room on a rotating wheel for $10 \mathrm{~min}$. Spheroplasts were lysed using glass beads by vortexing at maximum speed for 6 min with intermittent cooling on ice. The unlysed cells and glass beads were pelleted by centrifuging at maximum speed for $3 \mathrm{~min}$. The supernatant, cell lysate, was collected and the protein content was estimated.

\section{b. Preparation of cell lysates using DEAE dextran}

Cells were pelleted at $5000 \mathrm{rpm}$ for $5 \mathrm{~min}$. Cells were spheroplasted as described above. Spheroplasts were pelleted at $2000 \mathrm{rpm}$ for $2 \mathrm{~min}$. Spheroplasts were resuspended in $700 \mu \mathrm{l}$ of $0.1 \mathrm{M}$ sodium phosphate buffer. DEAE dextran was added to a final concentration of $50 \mu \mathrm{g} / 100 \mathrm{OD}_{600}$ (concentration of DEAE dextran had to be standardized for each strain). Spheroplasts were incubated on ice for $1 \mathrm{~min}$ and then at $30{ }^{\circ} \mathrm{C}$ for $5 \mathrm{~min}$. Cells were centrifuged at $2000 \mathrm{rpm}$ for $5 \mathrm{~min}$ to get the S5 fraction (homogenate).

\subsubsection{Subcellular fractionation}

Cells were pelleted at $5000 \mathrm{rpm}$ for $5 \mathrm{~min}$. Cells were spheroplasted as described above. Spheroplasts were pelleted at $2000 \mathrm{rpm}$ for $2 \mathrm{~min}$. Spheroplasts were resuspended in $700 \mu \mathrm{l}$ of $0.1 \mathrm{M}$ sodium phosphate buffer in presence of preotease inhibitors. Cells were lysed with DEAE dextran. $500 \mu \mathrm{l}$ of S5 fraction was centrifuged at $13000 \mathrm{rpm}$ for $10 \mathrm{~min}$ to obtain the $\mathrm{S} 13$ and P13 fractions. S13 fraction was then centrifuged at $50000 \mathrm{rpm}$ for 20 min to obtain the S200 (cytosolic proteins) and the P200 fraction (membrane proteins). P13 and P200 fractions were resuspended in $500 \mu \mathrm{l}$ of phosphate buffer with protease inhibitors added.

\subsubsection{Glycerol Density Gradients}

(reference: Kim et al 1997)

Glycerol solutions

$20 \% \quad 2.52 \mathrm{~g}$ glycerol in $10 \mathrm{ml} 20 \mathrm{mM}$ PIPES, pH 6.8

$30 \% \quad 3.78 \mathrm{~g}$ glycerol in $10 \mathrm{ml} 20 \mathrm{mM}$ PIPES, pH 6.8 
$40 \% \quad 5.04 \mathrm{~g}$ glycerol in $10 \mathrm{ml} 20 \mathrm{mM}$ PIPES, pH 6.8

$50 \% \quad 6.30 \mathrm{~g}$ glycerol in $10 \mathrm{ml} 20 \mathrm{mM}$ PIPES, pH 6.8

Cells were grown to a mid log phase at $30^{\circ} \mathrm{C}$ in a shaking incubator. Cells were pelleted at $5000 \mathrm{rpm}$ for $5 \mathrm{~min}$. Cells were spheroplasted using the protocol described in section 2.2.2.4. Spheroplasts were then lysed using glass beads. The protein content of the cell lysate was determined using the BIORAD method. 20-50 $\%$ glycerol gradients were made using $450 \mu \mathrm{l}$ of each of the solutions. The gradients were allowed to linearize for 4 hours in the cold room. $1200 \mu \mathrm{g}$ of protein was loaded onto the gradient. The gradients were centrifuged at $55000 \mathrm{rpm}(260000 \mathrm{~g})$ for 4 hours at $15^{\circ} \mathrm{C}$ using the Beckman TLS55 rotor. 10 fractions were collected from each of the gradients and TCA precipitated. The proteins were solubilised in Laemmli buffer and analysed by SDS PAGE followed by western blot.

\subsubsection{Gel filtration}

Gel filtration is a chromatographic technique which separates the proteins based on their relative size. Chromatography is performed using the porous beads as chromatographic support. A column of gel particles is in equilibrium with a suitable mobile phase for the molecules to be separated. Large molecules that are completely excluded from the pores elute first. Smaller molecules are distributed between the mobile phase inside and outside the molecular sieve and then pass through the column at a slower rate, hence elute later. The porosity of the gel particles and the size of the molecules to be separated determine the quality of separation.

Superdex 75 PC 3.2/30 and Superdex 200 column were used for the experiments. The Superdex column consists of dextran and crosslinked agarose. Superdex 75 has an exclusion limit of $100 \mathrm{kDa}$ and Superdex 200, an exclusion limit of $1300 \mathrm{kDa}$.

The column was installed in the SMART system and equilibrated with the buffer (in which protein extracts were made) with at least one column volume $(2.4 \mathrm{ml})$. All the buffers used for the column were made with made with HPLC water, filtered and degased. The column was calibrated using a protein standard solution containing Transferrin, BSA, Albumin, Carbonic anhydrase and Cytochrome C. 
Cells were made into spheroplasts and homogenized with potter. S200 fraction was collected. $100 \mu \mathrm{g}$ of protein was loaded onto the column at a flow rate of $40 \mu \mathrm{l} / \mathrm{min}$. Elution fractions of $50 \mathrm{ml}$ were collected $20 \mathrm{~min}$ after the load.

\subsubsection{Ape1p activity by overlay assay}

Ape1p enzymatic activity of yeast colonies was determined by Ape1p overlay assay. To test the activity of the enzyme, an overlay agar containing leucine- $\beta$-naphthylamide (H-Leu- $\beta$-NA) as substrate was prepared. Chloroform was used to permeabilize cells. Aminopeptidase I catalyses the cleaveage of H-Leu- $\beta$-NA and $\beta$ naphthylamide is released ( $\beta$-NA) which is fluorogenic. Hence fluorescence is observed at $365 \mathrm{~nm}$.

Assay-agar mixture

Tris $/ \mathrm{HCl} \quad 50 \mathrm{mM} \mathrm{pH} 7.5$

EDTA $2 \mathrm{mM}$

Agarose $\quad 0.6 \%$

H-Leu- $\beta$-NA $\quad 10 \mathrm{mM}$

Fresh cells are used for the assay. Colony streaks were made on YPD plates and incubated O.N. at $30^{\circ} \mathrm{C}$. Chromatographic paper filters $(80 \mathrm{~mm}$, Schleicher ans Schuell) were placed on the YPD plates and let stand until the entire filter turned wet. The replica-filters were taken off from the plates, transferred onto YPD plates with the colony side up and incubated overnight at $30^{\circ} \mathrm{C}$. Next day, the filters were taken from the plates and placed in $\mathrm{CHCl}_{3}$ with colony side downward for $15-20 \mathrm{sec}$. Excess $\mathrm{CHCl}_{3}$ was removed by drying the filters on paper towels. These were then placed in Petri plates and overlayed with assay-agar mixture. The mixture was prepared by mixing the buffer and agarose in a falcon tube. Substrate solution was prepared and added immediately to the assay mixture which was poured onto the petri plates containing the filters. Plates were incubated for 10-15 min at RT. Activity of Ape $1 \mathrm{p}$ was detected at $365 \mathrm{~nm}$ using an UV-lamp. 


\subsubsection{Immunofluorescence microscopy}

Fixative: $1 \mathrm{~g}$ of paraformaldehyde is dissolved in $25 \mathrm{ml}$ of water by heating above 60 ${ }^{\circ} \mathrm{C}$. $187.5 \mu \mathrm{l}$ of $6 \mathrm{~N} \mathrm{NaOH}$ is added and then $0.34 \mathrm{~g}$ of potassium hydrogen phosphate is added. The $\mathrm{pH}$ of the solution is 6.5 .

TE $\beta$ buffer (5 ml)

Tris/HCl pH 8.0 $200 \mathrm{mM}$

EDTA $20 \mathrm{mM}$

$\beta$-mercaptoethanol $1 \%$

Spheroplasting buffer $(5 \mathrm{ml})$

Sorbitol $1.2 \mathrm{M}$

Potassium phosphate ph 7.3 $50 \mathrm{mM}$

Magnesium chloride $1 \mathrm{mM}$

Sorbitol-Azide (5 ml)

Sorbitol $1.2 \mathrm{M}$

Sodium azide $5 \mathrm{mM}$

Sorbitol-SDS (10 ml) $10 \% \mathrm{w} / \mathrm{v}$ SDS $2 \%$

Sorbitol $1.2 \mathrm{M}$

Sodiumazide $5 \mathrm{mM}$

PBS-BSA-Azide (50 ml)

BSA

Sodiumazide 10X PBS
$5 \mathrm{mg} / \mathrm{ml}$

$5 \mathrm{mM}$

$1 \mathrm{X}$

On day I the cells were streaked on SD plate and incubated overnight at $30^{\circ} \mathrm{C}$. On day II, $5 \mathrm{ml}$ of SD medium was inoculated with cells and grown overnight at $30^{\circ} \mathrm{C}$. Next day, cells equal to $2.5 \mathrm{OD} 600$ were harvested and $10 \mathrm{ml}$ of YPD medium was inoculated and incubated for $4 \mathrm{hrs}$ at $30^{\circ} \mathrm{C}$. Cells were then fixed by adding 1-1.2 ml of $37 \%$ formaldehyde (final concentration $3.7 \%$ ), incubated for $30 \mathrm{~min}$ in the shaker. 
Cells were harvested and resuspended in $2 \mathrm{ml}$ fixative and incubated overnight at room temperature on the rocker. Fixed cells were harvested and suspended in $1 \mathrm{ml}$ $\mathrm{TE} \beta$ for $10 \mathrm{~min}$. Spheroplasts were obtained by incubating with zymolyase at $30{ }^{\circ} \mathrm{C}$ with gentle shaking. While cells were spheroplasting, slides (8-well multitest slides) were prepared. $20 \mu \mathrm{l}$ of $1 \mathrm{mg} / \mathrm{ml}$ polyL-lysine in water was added to each well and allowed to sit for $1 \mathrm{~min}$. Each well was washed with $25 \mu \mathrm{l}$ of water (6 times). Aspirated and allowed to air dry. Spheroplasted cells pelleted at $6500 \mathrm{rpm}, 30 \mathrm{sec}$ and washed once with $1 \mathrm{ml}$ of $1.2 \mathrm{M}$ sorbitol containing $5 \mathrm{mM}$ sodium azide and repelleted. Cells were resuspended in $1.2 \mathrm{M}$ sorbitol containing $10 \%$ SDS and incubated for $2 \mathrm{~min}$. cells were pelleted at $6500 \mathrm{rpm}, 30 \mathrm{sec}$ and washed twice with 1 $\mathrm{ml}$ of $1.2 \mathrm{M}$ sorbitol. Cells were resuspended in appropriate volume of $1.2 \mathrm{M}$ sorbitol depending on the size of the pellet. $40 \mu$ of cells per well were added and allowed to settle for $10 \mathrm{~min}$. Remaining cells were aspirated and each well was washed 3 times with 20-25 $\mu \mathrm{l}$ of PBS-BSA. The slides were allowed to sit in humid chamber for 15 min at room temperature. Wells were aspirated and primary antibody was added and incubated for $1 \mathrm{~h}$ at room temperature. Cells were washed with 20-25 $\mu$ l of PBS-BSAazide 6 times. Secondary antibody was added and incubated for $1 \mathrm{~h}$. Cells were washed 6 times with PBS-BSA-azide. $10 \mu$ of DAPI $(1 \mathrm{mg} / \mathrm{ml})$ was added, cells were allowed to sit for $10 \mathrm{~min}$ and washed with PBS-BSA-azide 3 times. $8 \mu$ of mounting media was added in each well, slides were covered with coverslip and allowed to settle. After $5 \mathrm{~min}$, ends of the coverslips were sealed with nail polish. Slides were viewed under a confocal laser-scanning microscope. DAPI staining was examined at $395 \mathrm{~nm}$. 


\section{Results}

In order to clone the via-genes and via mutant suppressors, both the mutants were transformed with two yeast DNA libraries. One library was provided by H.D. Schmidt (MPI for biophysical chemistry, Göttingen) and the other by C. Sengstag (ETH Zürich). In the course of the cloning attempts it was noticed that the low transformation frequency of via mutants was further reduced by the increasing plasmid size. Cloning attempts with both the libraries were not successful.

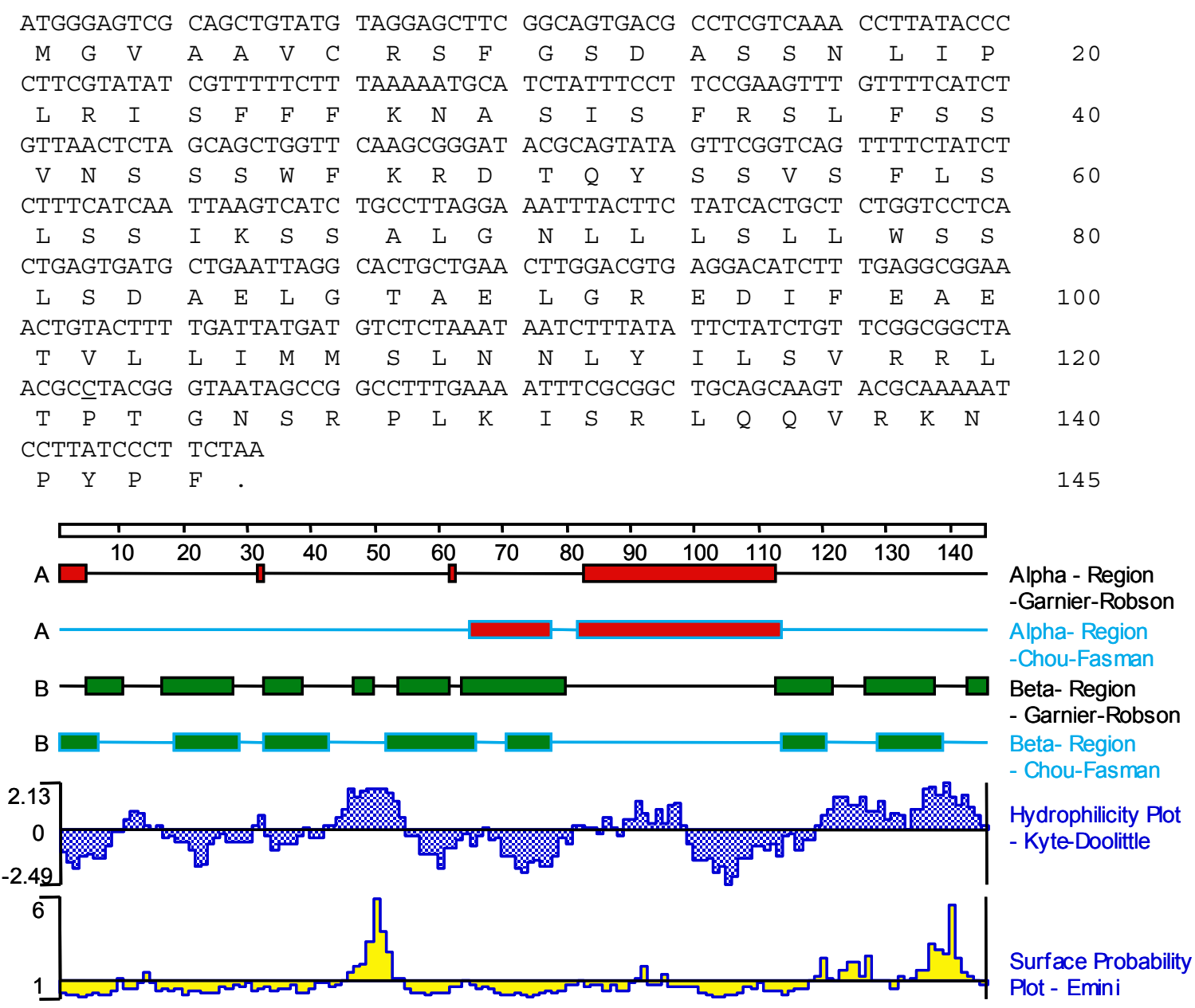

Fig 7: DNA and peptide sequence of YDR360W as isolated from the wt strain.

Therefore a DNA library was constructed using the isogenic wild-type strain and the small pRS 316 vector. 
DNA fragments varying from $2-5 \mathrm{~kb}$ were isolated and subcloned to limit the size of the resulting library plasmids. This isogenic library was used to transform via mutants using the Li/Acetate method (2.2.1.2). Colonies were replica plated on YPD medium to suppress the degradative autophagy pathay and screened for Ape $1 p$ enzymatic activity by the Ape1p overlay assay with Leu- $\beta$-napthylamid as substrate (2.2.2.8). Colonies showing maximum activity were recovered and retested for Ape $1 p$ enzymatic activity. A plasmid was identified carrying a $1.5 \mathrm{~kb}$ fragment on chromosome IV with the ORF YDR360w. Sequencing of ORF YDR360w isolated from the wt strain revealed a larger reading frame than the sequence given in the yeast genome data library. The ORFs isolated from via10 and via14 mutants were identical to the ORF from the wt strain. The ORF sequence from wt had an additional 'C' (Fig 7), causing a frameshift and an ORF encoding 145 instead of 129 aa. Secondary structure analysis predicts $\mathrm{N}$-terminal $\beta$-sheets and an $\alpha$-helical domain between amino acids 83-112.

To test whether the expression of YDR360w is reduced, a northern blot experiment was performed. Total RNA was isolated from the wt, via 10 via14 strain and the deletion strain of YDR360w, which was obtained from the EUROSCRAF (Frankfurt.M.) which has collection of yeast knock out strains. Northern blot experiment was done as described in materials and methods (2.2.1.3).10 $\mu \mathrm{g}$ of RNA from each were loaded and hybridized with ${ }^{32} \mathrm{P}-\mathrm{d}$ CTP labeled YDR360w. It was observed that the expression of mRNA was comparable in wt and via mutant strains and no signal was observed in ydr360w $\Delta$ strain. This experiment demonstrates that the transcription of YDR360w is not reduced in the via mutants and is normal (Fig 8). 


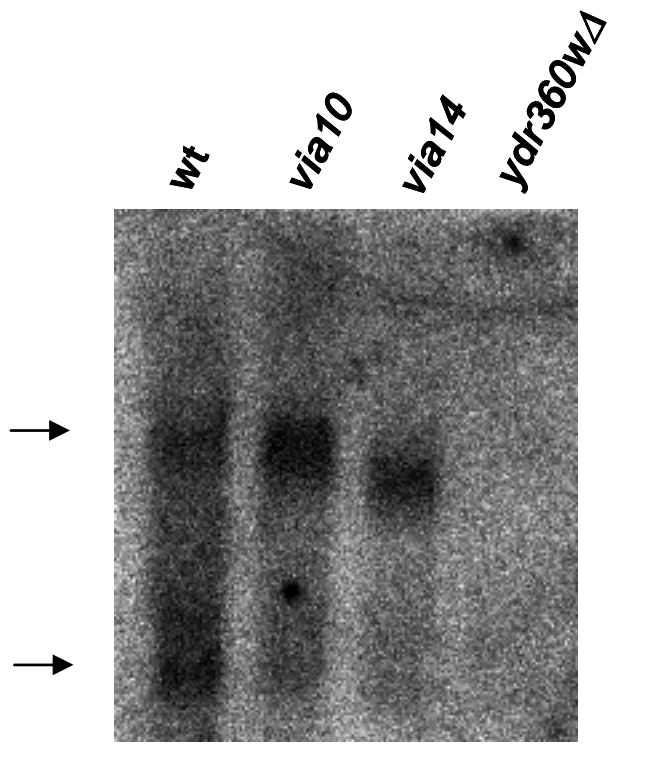

B

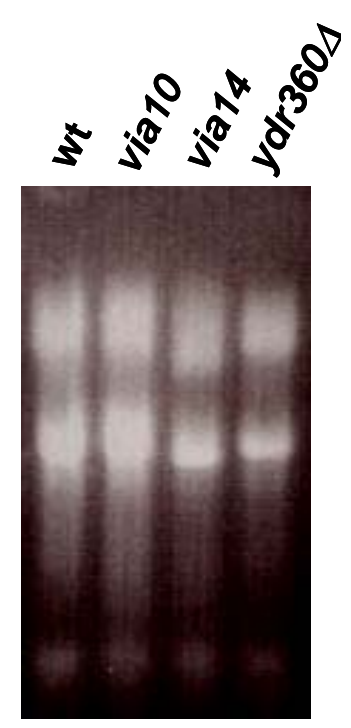

B

Fig 8: Expression of YDR360w gene at mRNA level in wt and via mutants. A: Northern blot showing the expression of mRNA was normal in wt and via mutants for YDR360w gene. No signal for YDR360w was observed in ydr360w $\Delta$ strain. B: Agarose gel showing that comparable amounts of RNA loaded (upper band). Arrows indicate the position of rRNA. 10 $\mu \mathrm{g}$ of RNA was loaded in each lane from wt, via10, via14 and ydr360w $\Delta$ strain.

\subsubsection{SUVIA1 is a suppressor of via mutants}

The ORF YDR360w was amplified by PCR from the genomic DNA of the parental wt strain and via mutants. The ORF was cloned into cen (single-copy) pYX141 and $2 \mu$ (multi-copy) pYX242 yeast expression vectors using EcoRI and Hindlll restriction sites. The via mutants were transformed with YDR360w plasmid carrying Leu as the auxotrophic marker. Since Ape $1 \mathrm{p}$ is expressed from a His plasmid, transformants were selected on plates lacking $\mathrm{His}$ and Leu. The colonies obtained after transformation were analyzed for Ape1p enzymatic activity by overlay assay.

via10 has $20 \%$ of the wt Ape1p enzymatic activity and via14 does not show any enzymatic activity. When the ORF was expressed in the via mutants, the mutants with both cen and $2 \mu$ Suvia1p plasmid had Ape1p enzymatic activity comparable to the wt cells (Fig 9). 


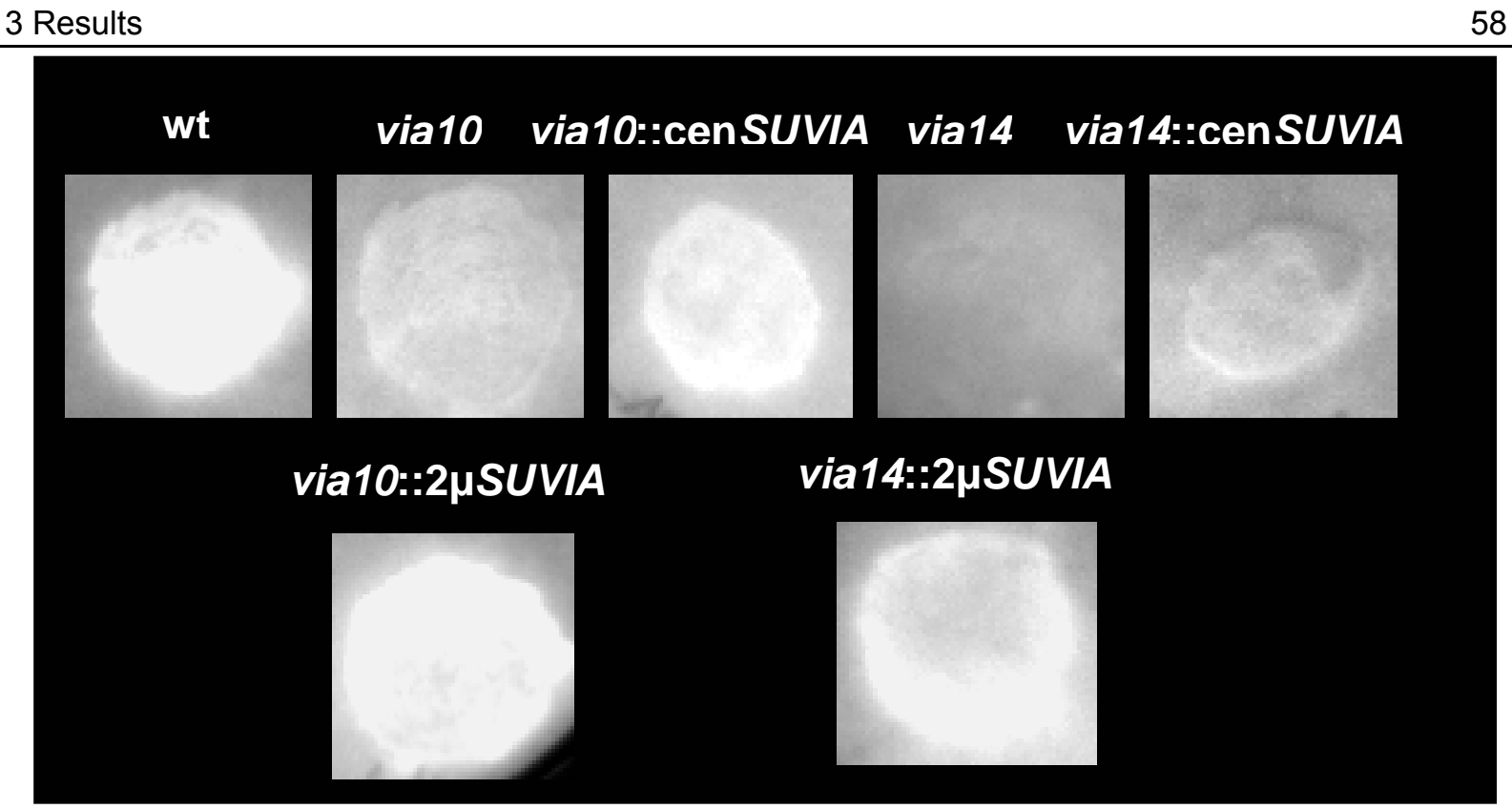

Fig 9: Ape1p-overlay assay for testing the Ape1p enzymatic activity. The image was recorded at $365 \mathrm{~nm}$ using a CCD chemiluminescence camera. Strains with Ape1p enzymatic activity emit fluorescent light and colonies become visible.

Because YDR360w isolated from via10 and via14 did not show any mutations, YDR360w should be a suppressor of via10 and via14. Since ORF YRD360W suppresses the defect in the via mutants, and is not mutated itself, it is termed as SUVIA1 "suppressor of via".

\subsubsection{Ape1p expression and processing is enhanced by Suvia1p}

Suvia1p expression could lead to higher pApe1p expression due to the formation of native and stable dodecamers and also enhanced vacuolar transport of pApe1p. To investigate this, protein extracts were made from cells grown at $30^{\circ} \mathrm{C}$ in nutrient-rich medium (YPD) until logarithmic phase between OD $600=0.7-1.2$ (when Cvt pathway is active) and stationary phase OD 600 above 2.0 (when autophagy is active). Cells were converted into spheroplasts and lysed with glass beads (2.2.2.4). Crude cell extracts were prepared in the presence of protease inhibitors to analyze Ape1p expression and processing in Suvia1p transformed via mutants. Proteins were detected on SDS-PAGE and blotted onto nitrocellulose membrane. Ape1p was detected using a rabbit anti-Ape1p antiserum. Blots were also developed with mouse anti-CPY antiserum as a control for the quantification of Ape1p signals (Fig 10). 
The signal intensities for precursor aminopeptidase (pApe1p) and mature form (mApe1p) were quantified, using the signals for vacuolar carboxypeptidase $Y$ which reaches the vacuole through the secretory pathway. The expression level and processing of Ape $1 \mathrm{p}$ is depicted in the graph.

A

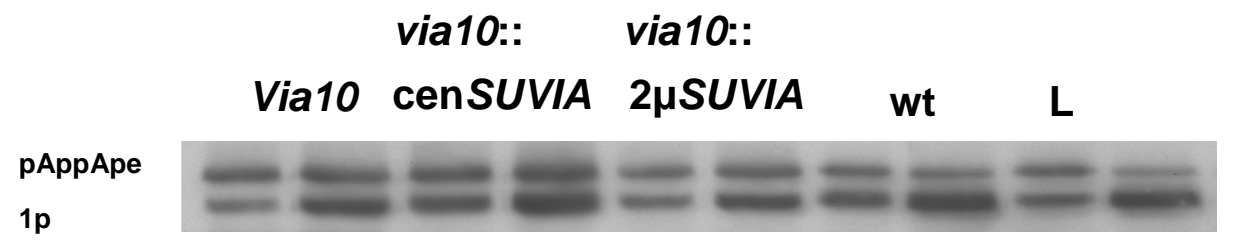

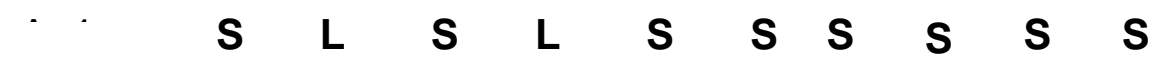

CPY

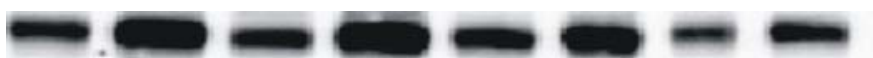

B

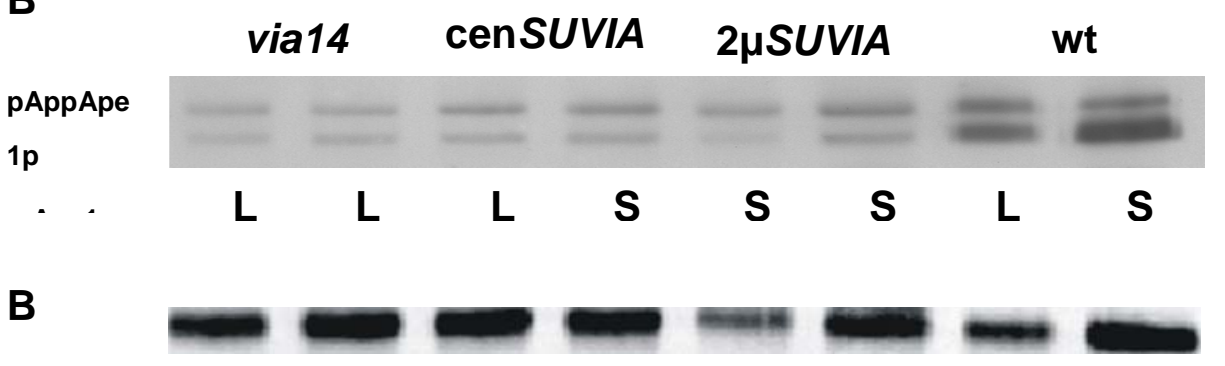

Fig 10: Western blot analysis of via mutants transformed with Suvia1p. Protein extracts were made from logarithmically $(L)$ and stationary $(S)$ cultures grown in rich media. A. Protein extracts from via10 and Suvia1p transformants. B. Protein extracts from via14 and Suvia1p transformants. $10 \mu \mathrm{g}$ of protein from wt and $20 \mu \mathrm{g}$ of protein from the other strains were loaded. CPY served as internal control.

In via mutants, the pApe $1 \mathrm{p}$ form is more abundant than in the wt demonstrating a defect in Cvt pathway. Both mutants express low levels of Ape1p as the protein is present in a non-native conformation, which leads to enhanced proteolytic cleavage. When Suvia1p is expressed in via mutants, the expression level of Ape1p is two-fold. 
Suvia1p not only improves the expression levels of Ape1p in via mutants, but also has an effect on processing and thus vacuolar transport of Ape1p in the mutants. Under logarithmic phase, when the Cvt pathway is active, wt cells have $30 \%$ of Ape1p as pApe1p, where as via10 accumulates 60-70\% of Ape1p as precursor form. When Suvia1p is expressed in the via mutants from cen or $2 \mu$ plasmids, the delay in processing is reduced to $45 \%$ in via mutants (Fig 11A).

A

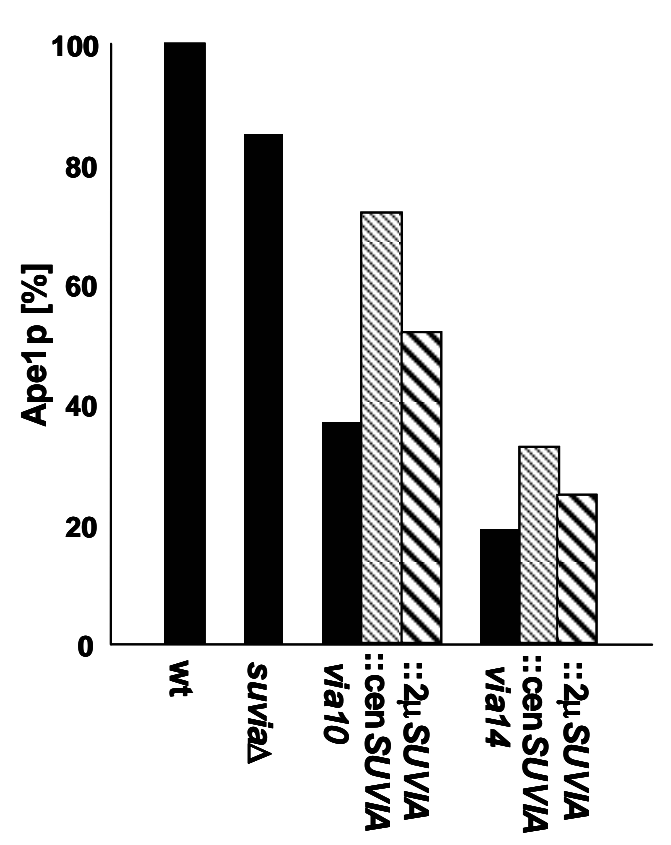

B

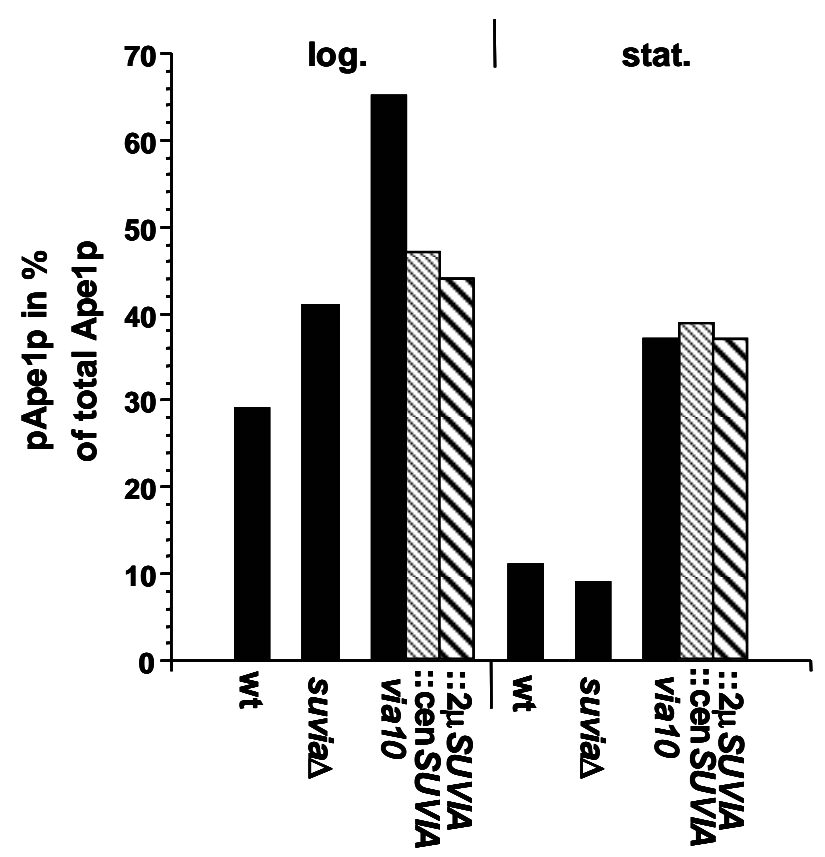

Fig 11: Graphical representation of Ape1p expression and processing in Suvia1p expressing via mutants. A) Expression levels of Ape1p increases two folds in via mutants.

B) Suvia1p expression enhances pApe1p processing along the Cvt pathway (log), but not along the autophagic pathway (stationary).

In stationary phase, where autophagy is induced by glucose starvation, wt shows only $10 \%$ of pApe1p, and pApe $1 p$ levels are reduced in via10 and via14 mutants and mApe1p is detected even in via14. Suvia1p has no effect in the processing of Ape1p when there is upregulation of autophagy under starvation conditions.Thus uponSuvia1p expression, via10 show increased levels of Ape1p and processing of pApe $1 p$ is enhanced during the vegetative growth phase. 
Suvia1p expression in via14, having the most severe phenotype, does not stimulate pApe1p transport.

\subsubsection{Suvia1p enhances dodecamerization of pApe1p}

The pApe $1 \mathrm{p}$ monomer assembles into a homododecameric complex in the cytoplasm with a half time of 2 min and the dodecameric complex of mApe1p is required for its enzymatic activity. via10 and via14 mutants do not form stable dodecamers of pApe1p. They are defective in complex assembly, form high molecular weight aggregates and Ape1p is rapidly degraded due to enhanced sensitivity to proteolysis (Andrei et al., 2001). To analyze the pApe1p complex assembly in via mutants expressing Suvia1p, Ape1p oligomers were separated on a glycerol density gradient (2.2.2.6). Crude protein extracts were prepared from cells grown in YPD to $\mathrm{OD}_{600}=$ 0.7-1.2 by breaking spheroplasts with glass beads in the presence of protease inhibitors. 10 soluble fractions of the glycerol gradient were collected and proteins were separated on $10 \%$ SDS-PAGE. Ape1p was detected by western blot analysis and signal intensities were quantified and are shown in the graph (Fig 12).

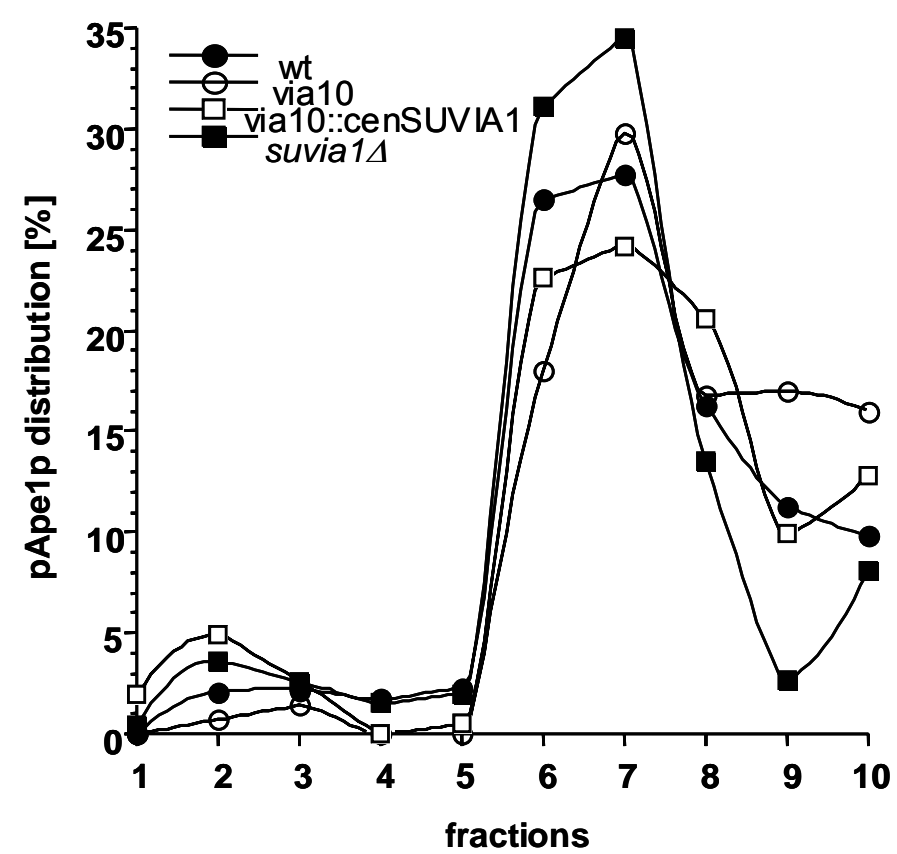

Fig 12: Oligomers of pApe1p and mApe1p separated on a glycerol gradient. Gradients were run for wt, via10, suvia $\triangle$ and via10::cenSUVIA. 10 fractions were collected from each ananalyzed by western blot and quantified. Numbers give the percentage of total pApe1p in the fractions. 
In wt cells, $90 \%$ of Ape $1 \mathrm{p}$ accumulated as dodecamers of pApe1p in fractions 6 and 7. In via10, dodecamers are seen in fractions 6 and 7, but the fractions 9 and 10 contain $\sim 40 \%$ of pApe $1 \mathrm{p}$ demonstrating a defect in complex assembly and formation of high molecular weight aggregates. In via10::cenSUVIA1, only $15 \%$ of pApe $1 \mathrm{p}$ is found in fractions 9 and 10 demonstrating enhanced formation of dodecameric complexes as indicated by the enzymatic assay. In suvia1 $\Delta$, the amount of pApe1p in fractions 9 and 10 is not increased compared to the wt and pApe1p is present as dodecamers. via14::cenSUVIA1 was not tested for dodecamerization of pApe1p because the suppression phenotype was as in via10::cenSUVIA1. This demonstrates that Suvia1p is not essential for pApe1p dodecamerization even though it supports formation of native dodecamers in via10.

\subsubsection{Suvia1p is required for Ape1p enzymatic activity}

Since Suvia1p is not required for the dodecamerization of pApe1p, we wanted to check, if Ape1p is enzymatically active in the absence of Suvia1p. wt and suvia1 $\Delta$ strains were mated and random sporulation (2.2.1.2) was done to generate spores lacking leucine aminopeptidase activity. Ape1p was then transformed and Ape1p activity test was done by the overlay assay. Ape1p did not show any enzymatic activity (Fig13) indicating that dodecamers are not in a native conformation. Thus Suvia1p is required for the formation of native dodecamers of Ape1p.

wt

suvia14

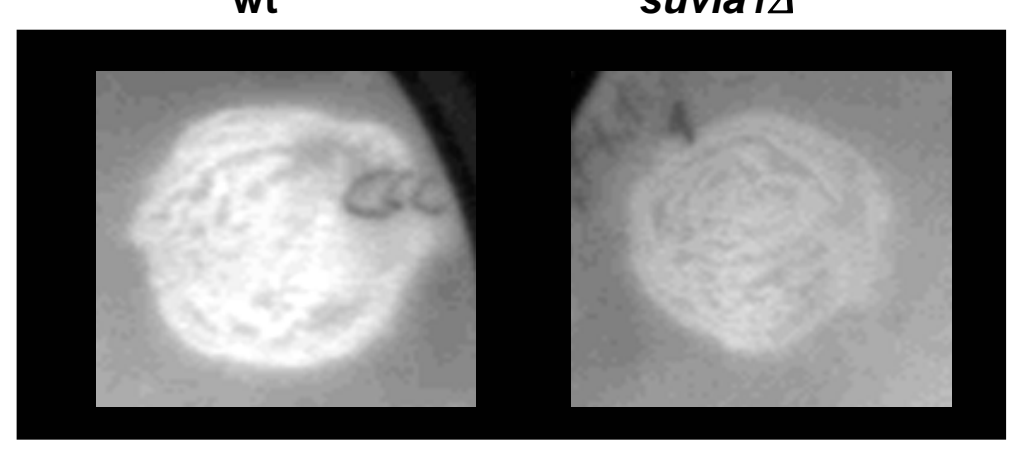

Fig 13: Ape1p is not enzymatically active in suvia1 $\Delta$ cells. Ape1p enzymatic activity was analyzed by overlay assay. suvia1 $\Delta$ cells lack Ape1p activity when compared to the wt cells. 


\subsection{Characterization of Suvia1p}

To further investigate and characterize Suvia1p, we wanted to generate antibodies against Suvia1p. Suvia1p was expressed in E.coli as a His ${ }_{6}$ and GST-tagged protein, but the fusion proteins either did not bind to the affinity matrix or formed insoluble inclusion bodies. A small fraction of GST-Suvia was soluble and could be purified, but rabbits did not produce anti Suvia1p antibodies. Therefore, Suvia1p was tagged with the hemagglutinin tag $(\mathrm{HA})$ at the $\mathrm{C}$ - terminus.

\subsubsection{HA-tagged Suvia1p complements Suvia1p-deficiency}

Suvia1p was cloned in pYX yeast expression vector to add the HA tag at the Cterminus using EcoRI and HindIII sites. We checked if Suvia1p-HA transformed in suvia1 $\Delta$ cells is biologically active by testing for Ape1p enzymatic activity.

suvsuvia1A

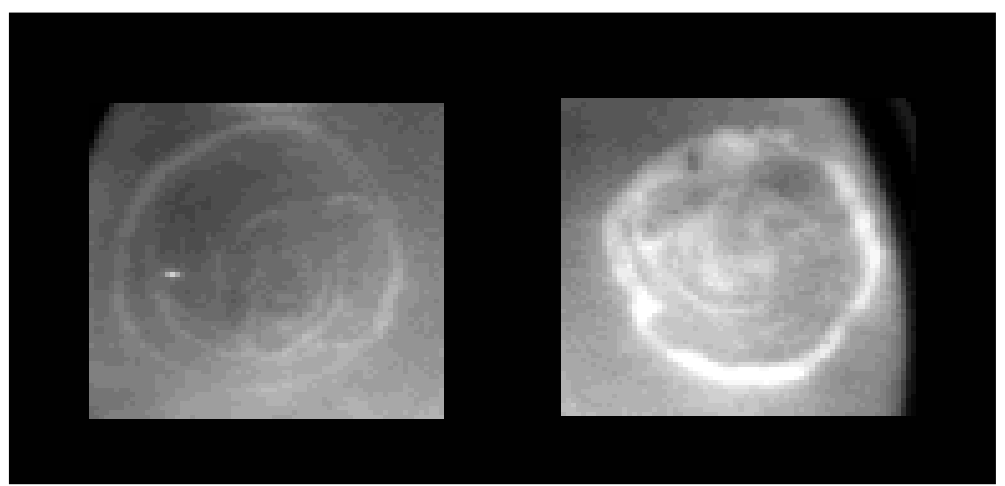

Fig 14: Suvia1p-HA complements Suvia1p deficiency: Suvia1p was transformed in suvia1. cells and Ape1p overlay assay was done. It was observed that HA-tagged Suvia1p complemented Ape1p activity in Suvia1p deficient cells.

Suvia1p-HA was able to complement Suvia1p deficiency demonstrating biological activity of the fusion protein. 
Suvia1p-HA clones were picked and crude cell extracts were made from the cultures grown until logarithmic phase. Spheroplasts were lysed with glass beads and proteins were separated on SDS-PAGE. Western blot was done and HA tagged Suvia1p was detected using anti-HA monoclonal mouse antiserum.

\section{SuvSuvia1p-HA}

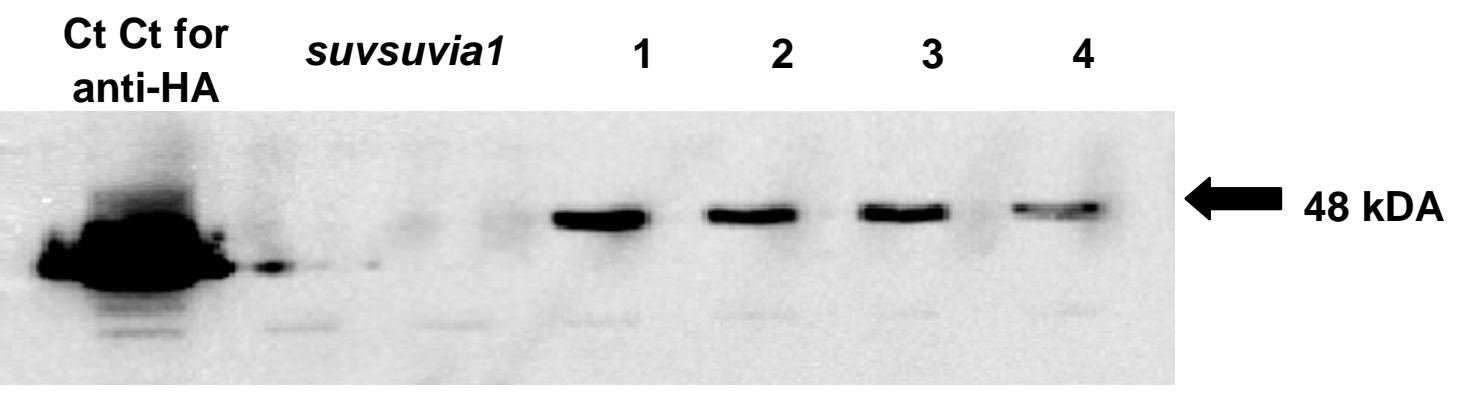

Fig 15: Western blot analysis of positive Suvia1p-HA clones. A positive control for HA tag (Use1pHA provided by Dr. G. Fischer Von Mollard) was loaded in the first lane. suvia1 $\Delta$ does not show any signal and Suvia1p-HA clones 1-4 show signal for anti-HA at 48 kDA (approximately).

Suvia1p is predicted to be a $16 \mathrm{kDa}$ protein based on the ORF. On SDS-PAGE Suvia1p-HA migrates at about $48 \mathrm{kDa}$ (Fig 15). This could be caused by incomplete denaturation or by a post-translational modification like phospho-rylation or covalent binding to a protein(s). Therefore we did gel filtration experiments (2.2.2.7) to confirm the molecular mass of Suvia1p-HA.

To determine the exact molecular weight of Suvia1p, gel filtration experiments were done in the presence of $6 \mathrm{M}$ urea. Suvia1p-HA cells were converted into spheroplasts in presence of $6 \mathrm{M}$ urea and homogenized with a potter. S200 fraction was prepared where Suvia1p is present described in the following section (3.2.2). This S200 fraction was prepared and $50 \mu \mathrm{g}$ of protein was loaded onto a Superdex 75 PC 3.2/3.0 column at a flow rate of $40 \mu \mathrm{l} / \mathrm{min}$. The column was calibrated with molecular weight standard proteins as given in materials and methods. Suvia1p-HA was detected in the fractions by western blot using anti-HA mouse monoclonal antiserum. 
A

Column fractions

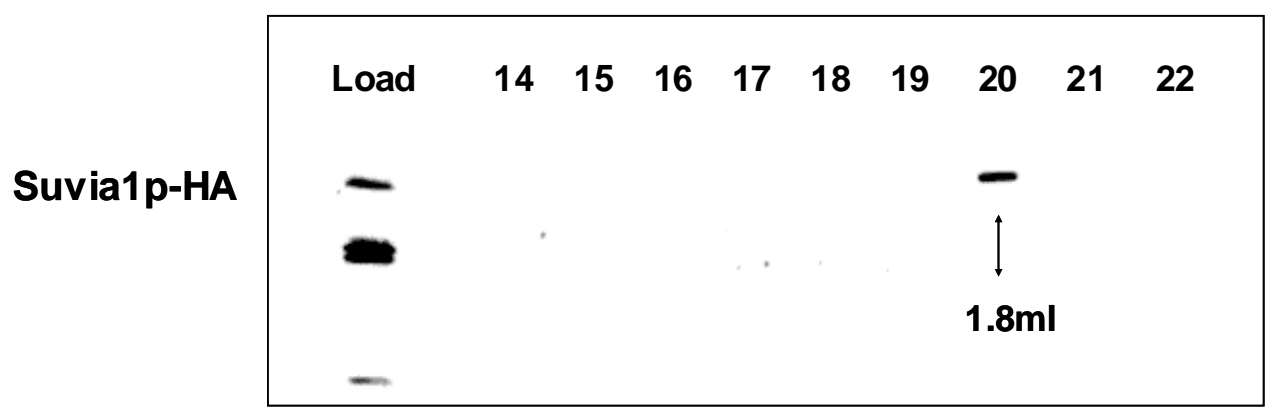

A

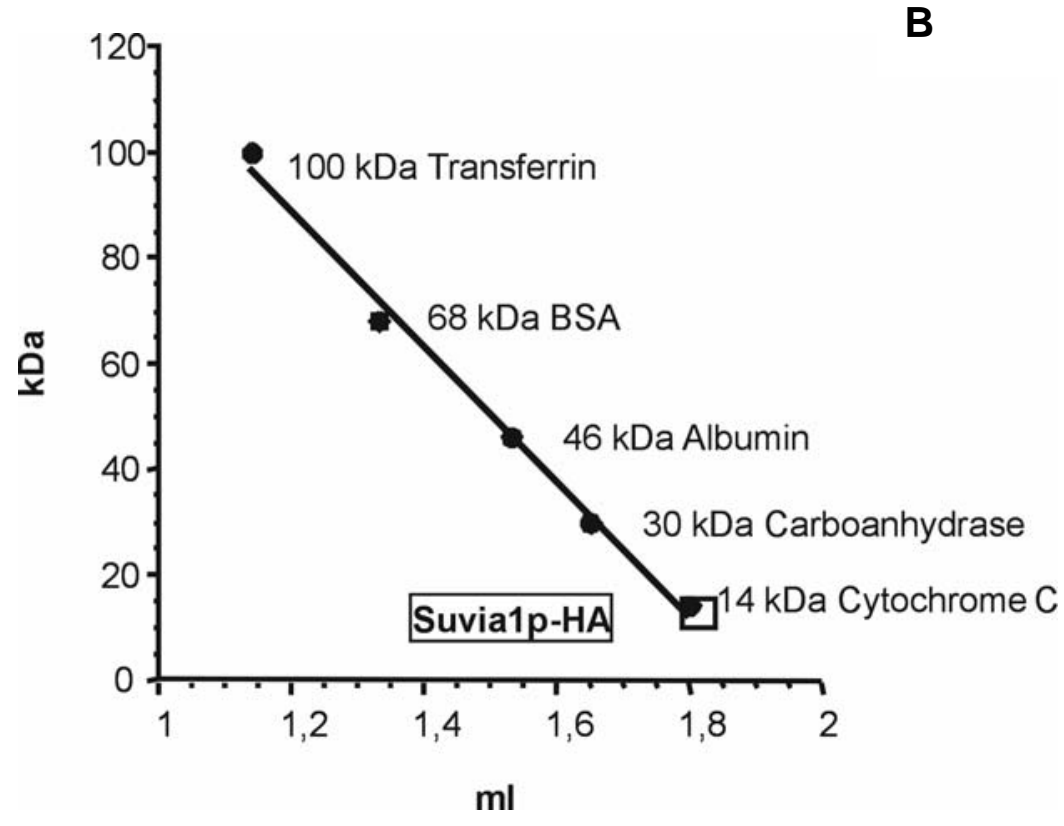

Fig 16: Gel filtration of Suvia1p-HA in Superdex 75 column: A. Western blot showing that Suvia1pHA was detected by anti-HA antiserum in column fractions 20. B. Suvia1p-HA was eluted at $1.8 \mathrm{ml}$ which corresponds to a molecular size of $\sim 14 \mathrm{kDa}$. Open box indicates fraction/molecular mass of Suvia1p-HA. $50 \mu \mathrm{g}$ of protein was loaded as reference in lane1.

Suvia1p-HA was detected in fractions which corresponded to a molecular mass of about $14 \mathrm{kDa}$ (Fig 16). Thus in presence of $6 \mathrm{M}$ urea Suvia1p was able to denature to its monomeric size of $16 \mathrm{kDa}$. 


\subsubsection{Suvia1p is a cytosolic protein}

To analyze the subcellular localization of Suvia1p, Suvia1p-HA expressing cells were fractionated and Suvia1p-HA distribution was followed by western blots for the HAtag. Cells were grown upto logarithmic growth phase and converted into spheroplasts. Spheroplasts were lysed with DEAE-dextran in presence of protease inhibitors at $30^{\circ} \mathrm{C}$ for $5 \mathrm{~min}$. The lysate was centrifuged at $500 \mathrm{~g}$ for $5 \mathrm{~min}$ to obtain the S5 fraction. The S5 fraction was centrifuged at $13000 \mathrm{rpm}$ for $10 \mathrm{~min}$ to get the $\mathrm{S} 13$ and P13 fractions. S13 fraction was further centrifuged at 200,000 $\mathrm{g}$ for $20 \mathrm{~min}$ to obtain S200 and P200 fractions (2.2.2.5). Aliquots of the fractions were loaded on $10 \%$ SDS-PAGE, followed by western blot to detect the proteins. Suvia1p-HA was detected by anti-HA monoclonal mouse antiserum.

\section{Ct suvia1ム S5 P13 S200 P200}

Fig 17: Subcellular fractionation of Suvia1p-HA. Suvia1p-HA was seen in S200 fraction. First lane is the positive control for anti-HA anti serum. Suvia1p is seen in S200 fraction.

Suvia1p-HA was exclusively detected in S200 fraction indicating that Suvia1p is a cytoplasmic protein.

\subsubsection{Suvia1p appears to be part of $200 \mathrm{kDa}$ complex}

Next spheroplasts were made in the absence of $6 \mathrm{M}$ urea and homogenized with a potter. Experiment was done in the same way as described for Superdex 75 column, except that speroplasts were made in the absence of $6 \mathrm{M}$ urea and sample was loaded on Superdex 200 column.The S200 fraction was prepared and $50 \mu \mathrm{g}$ of protein was loaded onto a Superdex 200 column at a flow rate of $40 \mu \mathrm{l} / \mathrm{min}$. 
B

\section{Column fractions}

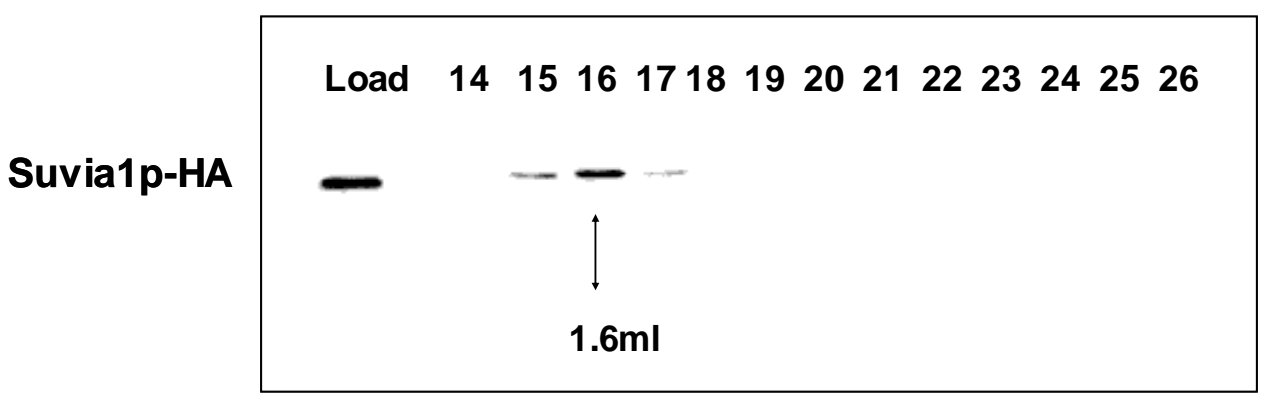

B

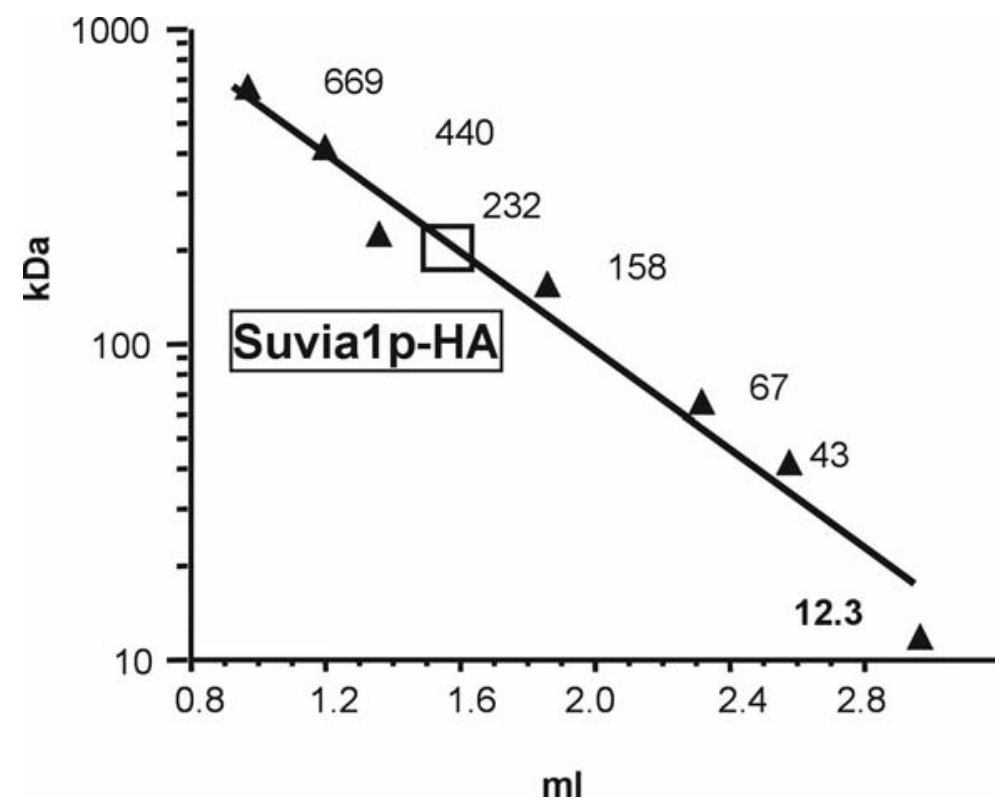

Fig 18: Gel filtration of Suvia1p-HA in Superdex 200 column: A) Western blot showing that Suvia1p-HA was detected by anti-HA antiserum in column fractions 15-17. B) Suvia1p-HA was eluted at $1.6 \mathrm{ml}$ which corresponds to a molecular size of $\sim 200 \mathrm{kDa}$. Open box indicates fraction/molecular mass of Suvia1p-HA. $50 \mu \mathrm{g}$ of protein was loaded as reference in lane1.

Suvia1pHA was detected in the fractions by western blot using anti-HA mouse monoclonal antiserum. Suvia1p-HA was exclusively detected in the fractions correspondings to a molecular weight of about $200 \mathrm{kDa}$ (Fig 18). Hence, Suvia1p is part of $200 \mathrm{kDa}$ complex. 


\subsubsection{Immunofluorescence microscopy of Suvia-1p}

To analyze subcellular distribution of Suvia1p in more detail, indirect immunofluorescence microscopy was done with Suvia1p-HA expressing cells. Cells grown until stationary phase $\left(O D D_{600}=2.5\right)$ were used for the experiment (2.2.1.9). Cells were fixed in paraformaldehyde overnight. Cells were converted into spheroplasts, which were then fixed on the slides.

A

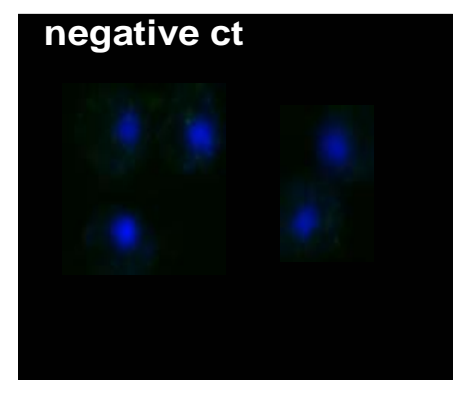

B

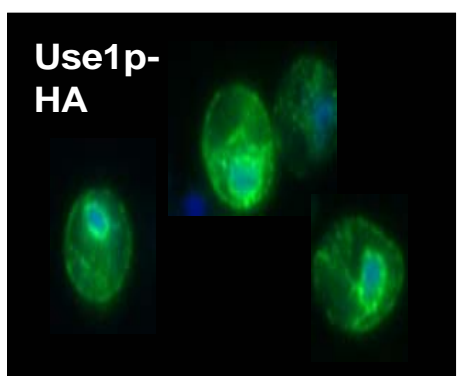

C

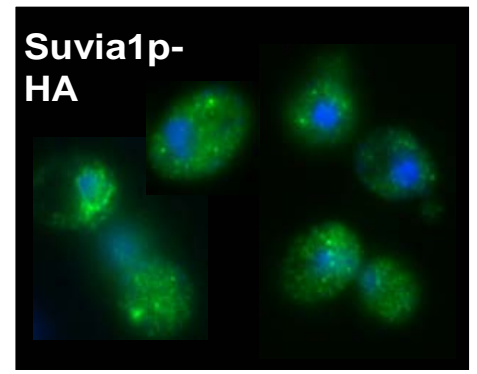

Fig 19: Localization of Suvia1p-HA. A: suvia1A as negative control. B: Use1p is the positive control for anti HA. C: Suvia1p-HA shows staining in the cytoplasm as dots.

The cells were stained with antibodies against HA. Suvia1pHA is localized in the cytoplasm as dots and concentrated as small structures. In suvia14, no staining is observed. The positive control Use1p-HA is localized to the ER and hence staining is seen around the nucleus.

\subsubsection{Suvia1p and Atg8p do not colocalize}

Since Suvia1p showed cytoplasmic concentration and because it appears to be involved in the formation of native Ape1p dodecamers, we thought it might be part of the pre-autophagosomal complex. Atg8p (Aut7p) is known to be a protein to localize to the pre-autophagosomal structure and is required for Cvt transport vesicle formation. Immunofluorescence microscopy of Suvia1p-HA and Atg8-GFP (construct provided by Prof. Ohsumi) was done to study the colocalization of the two protein. 
Atg Atg 8-

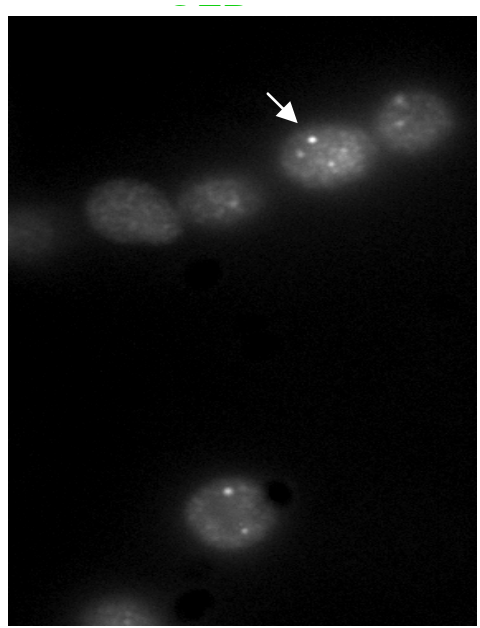

SuvSuvia-

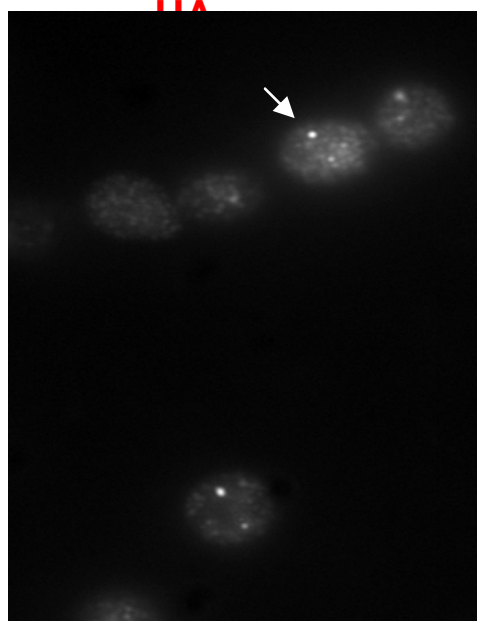

merme

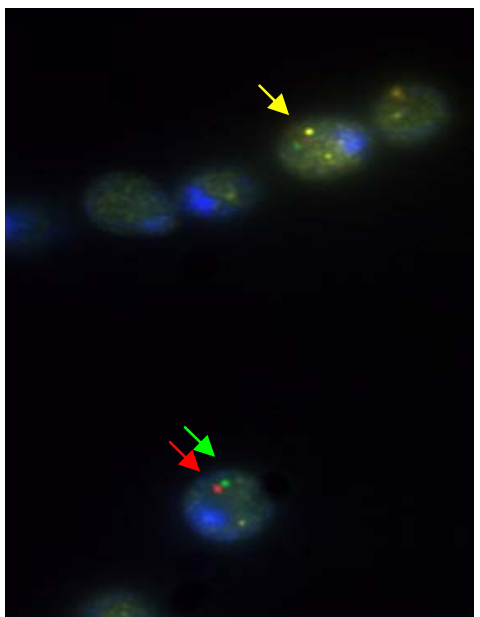

Fig 20: Immunofluorescence microscopy of Suvia1p and Atg8p. A: Aut7p-GFP is seen in green B: Suvia1p-HA in red and $C$ : is the merge of (a) and (b). Arrows indicate Suvia1p-HA in red and Atg8p in green.

Suvia1p-HA cells were transformed with Aut7p-GFP. Cells of OD $600=2.5$ were used for the experiment. Cells were fixed in paraformaldehyde overnight, converted into spheroplasts which were then fixed on the slides. The cells were stained with antibodies against anti-HA for Suvia1p-HA.

Suvia1p and Aut7p are localized to different cytosolic structures, which are however, in close proximity. Some structures appear yellow (arrow shown in yellow), indicating co-localization of Suvia1p and Atg8p (Aut7p) to the same structure, but sometimes they appear as two distinct spots next to each other. It could be possible that Suvia1p contain Atg8p at some point but all Atg8p do not have Suvia1p. However coimmunoprecipitation experiments failed to demon-strate co-localization (data not shown). The data demonstrate that the Suvia1p complex and the preautophagosomal structure are in close proximity, and that both complexes might even get in contact with each other. 


\subsection{Interaction of Suvia1p with Aminopeptidase I}

Suvia1p is required for the formation of native Ape $1 p$ dodecamers. Therefore, it was tested whether an interaction of Suvia1p-Ape1p could be demonstrated in vitro. GST pull-down experiments were used to study the interaction of Suvia1p with Ape1p (2.2.2.3).

Suvia1p was cloned into the vector pGEX-2T to express the fusion protein. Glutathione-S-transferase (GST) was fused at the N-terminus via a linker of 10 aa. GST-Suvia1p fusion protein was expressed in E.coli and isolated by binding to glutathione (GSH)-coupled Sepharose.

The molecular weight of Suvia1p and GST is $15 \mathrm{kDa}$ and $27 \mathrm{kDa}$ respectively. The molecular weight of GST-Suvia1p fusion protein will be $42 \mathrm{kDa}$. Western blot was done for the fractions in which the fusion protein was eluted and detected using antiGST goat antiserum.

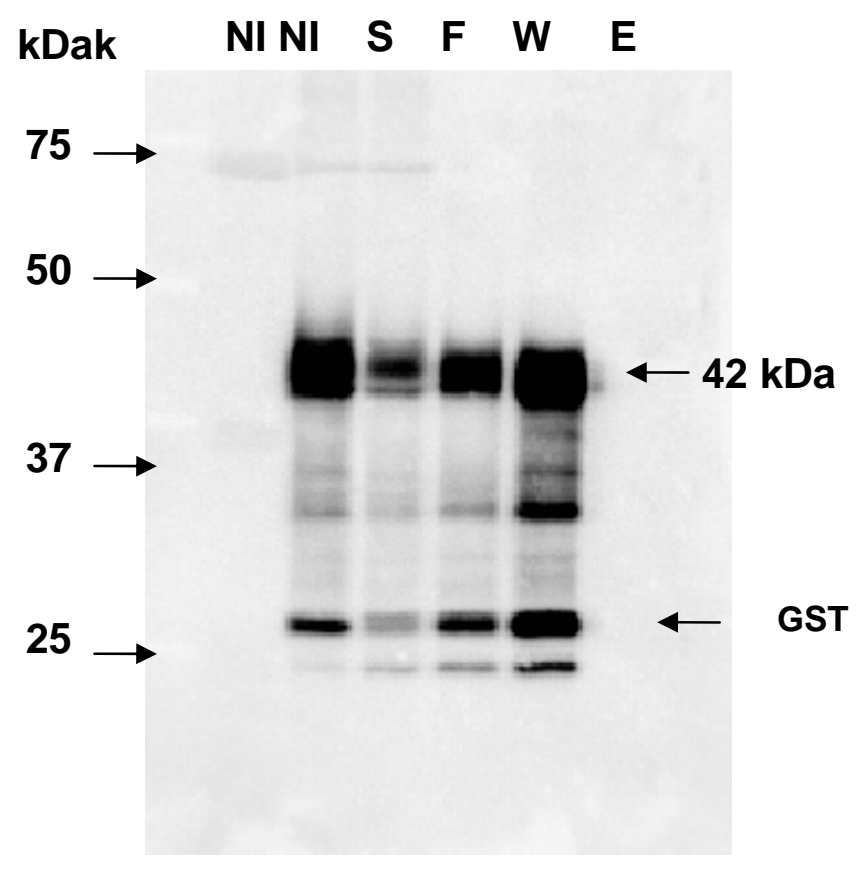

Fig 21: Western blot showing GST-Suvia1p fusion protein. $\mathrm{NI}$ is the non-induced fraction with no GST-fusion protein. $S$ is the supernatant fraction, $F$ is the flow through after the extract was incubated with the GSH Sepharose beads, $W$ is the wash fraction and $E$ is the eluate, where the fusion protein at $42 \mathrm{kDa}$ is observed in addition to free GST protein at $27 \mathrm{kDa}$. 
A signal at $42 \mathrm{kDa}$ was seen, which corresponds to the molecular weight of the GSTSuvia1p fusion protein (Fig 21).

To test, if GST-bound Suvia1p could pull down Ape1p, GST-Suvia1p was bound to sepharose beads. Protein extracts from wt and suvia1s cells were prepared after spheroplasting the cells. Cells were lysed with DEAE dextran $\left(90 \mu \mathrm{g} / 100 \mathrm{OD}_{600}\right)$ in the presence of protease inhibitors. $100 \mu \mathrm{g}$ of protein extracts were loaded on $50 \mu \mathrm{l}$ of GST-Suvia1p and GST-beads (as control) and incubated overnight at $4{ }^{\circ} \mathrm{C}$ on spinning wheel at a very slow speed. Next day beads were washed and proteins were eluted with buffer containing glutathione. All the fractions were loaded on $10 \%$ SDS-PAGE and analyzed by western blot. Ape1p was detected using a rabbit antiApe1p antiserum.
A
L $\quad \mathbf{F}$
F W
E1 E2
E3 E4
B

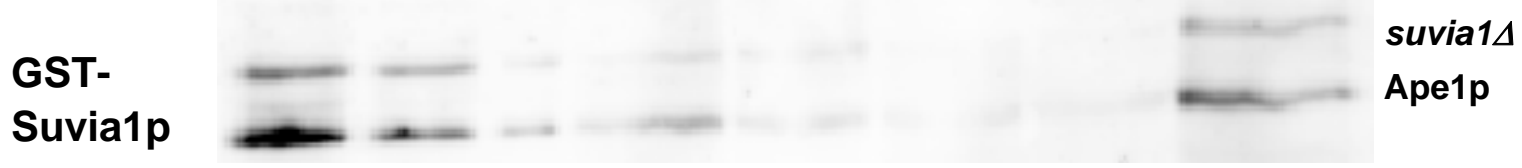

B

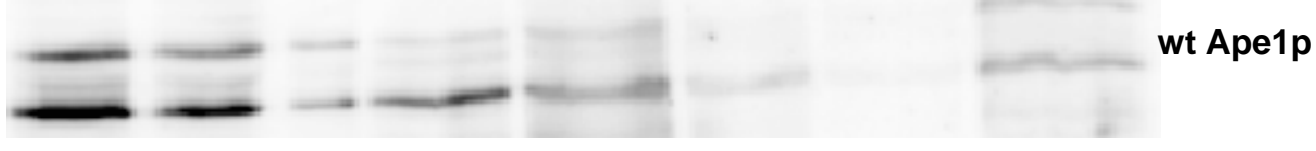

C

GST

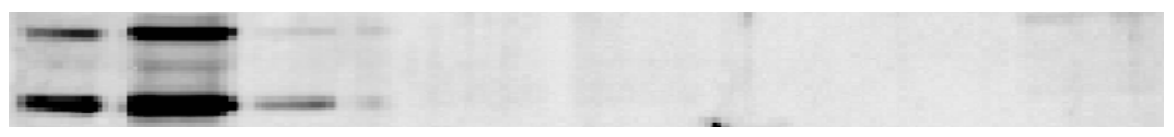

Fig 22: Interaction of Suvia1p with Ape1p from suvia $\Delta$ cells. A) Protein extracts from suvia1 $\Delta$ cells loaded on GST-Suvia1p beads. B) Protein extracts fron wt cells loaded on GST-Suvia1p beads. Protein extracts loaded on GST beads which served as a negative control. No signals of Ape1p was observed. 
The signals were quantified and it was observed that of the total protein from suvia1 1 cells that was loaded onto the GST-Suvia1p beads, only 15\% of Ape $1 \mathrm{p}$ from suvia1 $\Delta$ was bound to the beads. Bound Ape1p from suvia1 $\Delta$ were not efficiently eluted (Fig 22A). A large fraction of Ape1p was irreversibly bound to Sepharose beads. Only $6 \%$ could be eluted from the beads. The amount of protein that was bound and eluted is shown in (Fig 23).

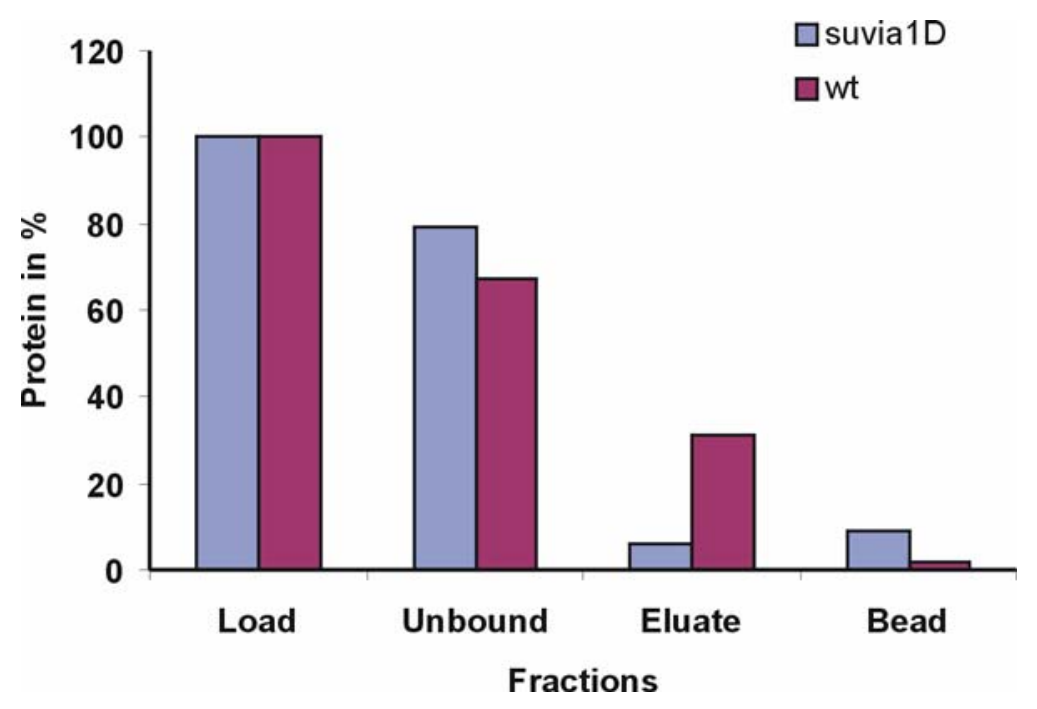

Fig 23: Signal intensities of Ape1p that was bound to the GST-Suvia1p beads. $79 \%$ of the protein remain unbound, $5.8 \%$ was eluted and $9 \%$ remained bound to the beads. $(\mathrm{N}=3)$

In case of protein extracts prepared from wt cells, $30 \%$ of the applied Ape $1 p$ was bound to the bead, out of which $33 \%$ of the protein was seen in the elution fractions and $\sim 2 \%$ of Ape $1 p$ remained bound to GST-Suvia1p beads (Fig 23). GST beads were used as control. No Ape1p should be eluted from GST beads as Suvia1p was not bound to the beads. When protein was loaded on to GST beads no Ape1p was observed in the eluate fractions (Fig 22C).

The data given here is the average of 3 different experiments. These experiments suggest that there exists a weak interaction between Suvia1p and Ape1p. There seems to be no specific binding to either pApep or mApe1p from wt or suvia1 $\Delta$ cells. Suvia1p-Ape1p interaction was also tested by yeast-two-hybrid $(\mathrm{Y} 2 \mathrm{H})$ experiments. 
The $\mathrm{Y} 2 \mathrm{H}$ system identifies DNA sequences encoding for proteins that are physically associated with a given protein in vivo. The MATCHMAKER Two-Hybrid Systems were used for the construction and expression of the hybid (fusion) proteins.

Full-length Suvia1p was cloned in GAL4 Activation Domain (AD) cloning vector pACT2 which has Leu as selection marker and full-length Ape1p was cloned in GAL4 DNA-Binding Domain (DNA-BD) cloning vector pAS2-1 which has Trp as selection marker. Both full-length proteins were expressed in the yeast tester strain AH109. AH109 is auxotrophic for leucine and tryptophan and also has four reporter genes (HIS3, ADE2, MEL1, and lacZ). Colonies were tested for adenine and $\alpha$ galactosidase which is extracellularly secreted and gives a blue colour around every positoive yeast colony.

No growth was observed in -Ade plates even after 5 days at $30{ }^{\circ} \mathrm{C}$. Colonies were also tested for $\alpha$-galactosidase, but no blue colour was observed. 


\subsection{Analysis of via10 and via14 genes}

\subsubsection{Microarray studies}

Because cloning of via10 and via14 genes by complementation was not successful, a DNA array analysis was done. Mutations in promoter sequences could lead to reduced mRNA expression levels and also mutations in the ORF could lead to mRNAs with reduced stability.

Microarray studies were performed to identify genes, where mRNA transcription was down-regulated. Total RNA was isolated from the wt and both mutant strains (2.2.1.3). cDNA-labelling experiments were done in collaboration with Dr. Andrease Polten (Agilent technologies), who introduced new yeast arrays.

$\begin{array}{lll}\text { Array } & \text { Cy3 } & \text { Cy5 } \\ 1 & \text { WT } & \text { via10 } \\ 2 & \text { via10 } & \text { via14 } \\ 3 & \text { via14 } & \text { WT }\end{array}$

Fig 24: Different sets of slides that were hybridized with labeled cDNAs from wt and via mutants. The cDNA were labeled with Cy3 and Cy5. The experiment was done in 4 sets to obtain the best result.

Microarray slides with 60mers corresponding to the 3'end of the 6253 annotated genes from S.cerevisiae were hybridized with labeled cDNAs from the isogenic wt and the 2 via mutants.

Combinations were used for hybridization: wt / via10, via10 / via14 and via14 / wt and each of these were labeled with fluorescent Cy 3 and Cy 5 respectively. Four sets of each combination were made for the analysis (Fig 24).

Mathematical calculations and data analysis of microarray studies were done by Dr. Jobst Landgrebe (Microarray facility, Medical faculty).

Comparisons were done between via10/wt, via14/wt and via10/via14 (Fig 25). 


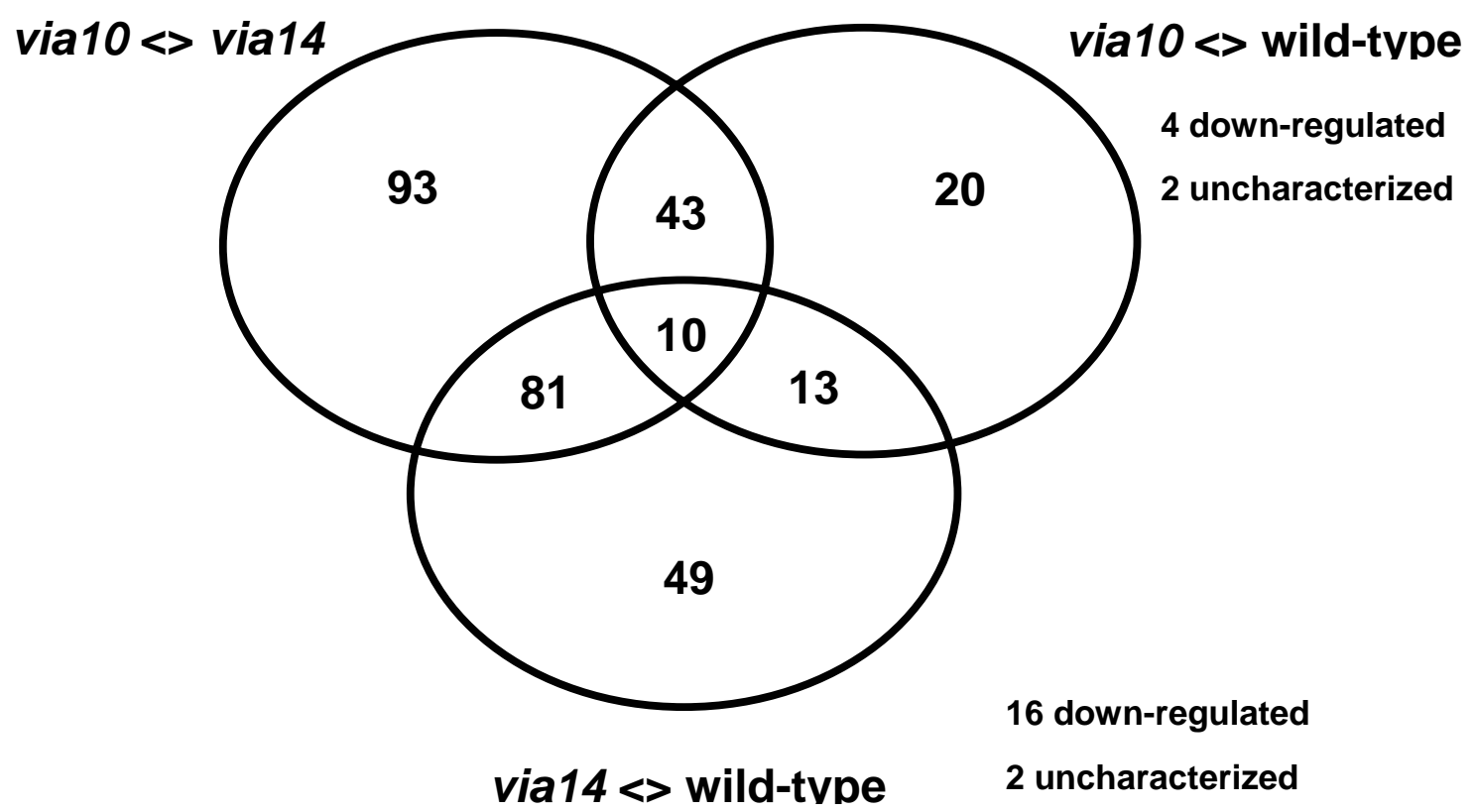

Fig 25: Comparison of the differentially expressed genes. via mutants were compared with the wt as well as with each other. The numbers represent the number of genes that were differentially expressed in the comparisons. No genes were differentially expressed in all three.

93, 20 and 49 are the total number of genes that were differentially expressed, either up-regulated or down-regulated when comparisons were made between via10/via14, via10/wt and via14/wt respectively. 43, 81 and 13 represent the numbers of genes that were differentially expressed and found common in the comparisons made between via10/via14 and via10/wt, via10/via14 and via14/wt, and via10/wt and via14/wt. 10 genes were found to be either up-regulated or down-regulated in all the three comparisons.

Interestingly when via10/wt were compared, out of 20, 4 genes were down-regulated, out of which 2 were uncharacterized. Similarly, when via14/wt were compared, out of 49, 16 genes down-regulated, out of which 2 were uncharacterized. No Atg or related genes were found to be differentially expressed in the via mutants. The four uncharacterized genes do not belong to any described category. Since our interest remained in analyzing the genes that were down-regulated, experiments were done to investigate the 4 candidate genes further. 


\subsubsection{Analysis of down-regulated genes in via mutants}

The four candidate genes that were down-regulated are YHR054cand YJL171c from via10, YER187w and YGL117w from via14. These four candidates were amplified from the genomic DNA of the wt, via10 and via14 strains by PCR. The amplified PCR products were cloned into pCR 2.1 vector and the ORF was sequenced to check, if there were any mutations in the ORFs. The table below indicates the genes that were down-regulated and their size.

\begin{tabular}{|c|c|c|}
\hline $\begin{array}{c}\text { Genes down- } \\
\text { regulated in via } \\
\text { mutants }\end{array}$ & ORF & Size in base pairs \\
\hline via10 & YHR054c & 1065 \\
& YJL171c & 1191 \\
\hline via14 & YER187w & 426 \\
& YGL117w & 798 \\
\hline
\end{tabular}

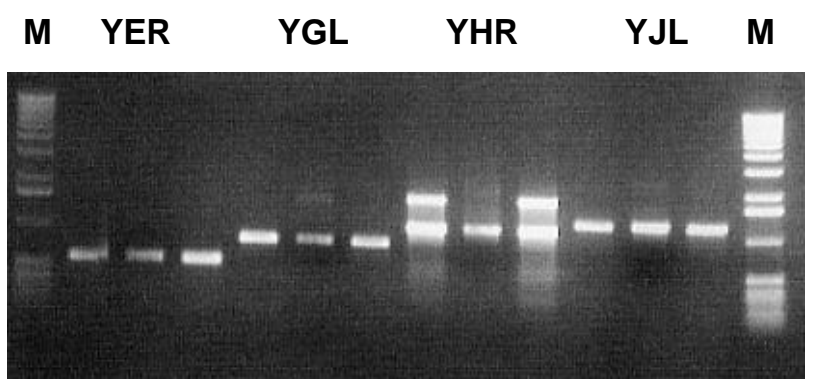

Fig 26: Agarose gel showing the amplified genes by PCR. The four genes that were downregulated in via mutants were amplified from the genomic DNA of wt and via mutants. $10 \mu \mathrm{l}$ of each sample was loaded in the order of wt, via10 and via14.

Mutations were found in the ORFs of the candidate genes amplified from via mutants. There was a single mutation at G42D in YHR054c amplified from via10 and 3 mutations at G42D, K28R and N87D in via14. 
No mutations were found in YJL171c ORF amplified from both the mutants. Single mutation was found at M1T in YER187w amplified from via14. In case of YGL117w, amplified from via14 a D45G mutation was found.

Next microarray data were verified by northern blot experiments for the two genes down-regulated in via10 (Fig 27) and in via 14 (Fig 28). Total RNA was isolated from wt, via10 and via14 strains and hybridized with radioactively labeled DNA probes (2.2.1.3). Actin was used as a control to standardize the hybridization signals of the via mutant RNAs.

\section{Genes down-regulated in via10}

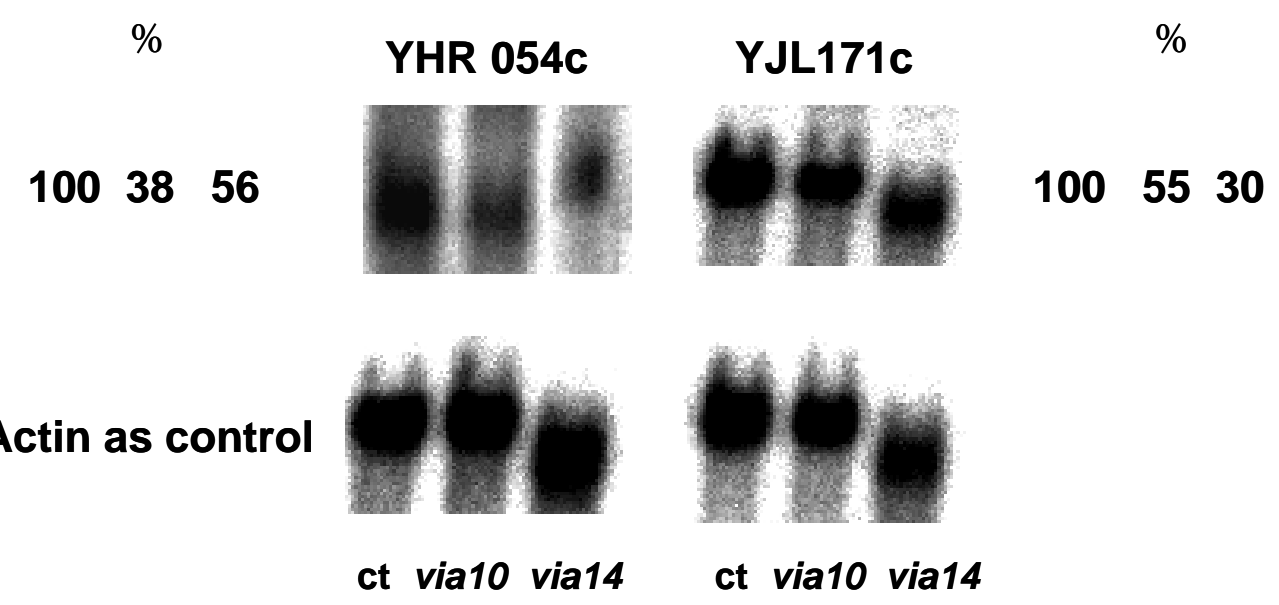

Fig 27: Northern blot showing reduced expression of down-regulated genes in via10 at mRNA level. In via10, YHR045c and YJL171c genes are down-regulated by $38 \%$ and $55 \%$ respectively. In via14, YHR054c and YJL171c genes were down-regulated by 56\% and 30\% respectively. Actin was used as control to normalize the via-gene signals. Numbers indicate the percentage by which the genes were down-regulated. $10 \mu \mathrm{g}$ of RNA was loaded for each sample. 


\section{Genes down-regulated in via14}

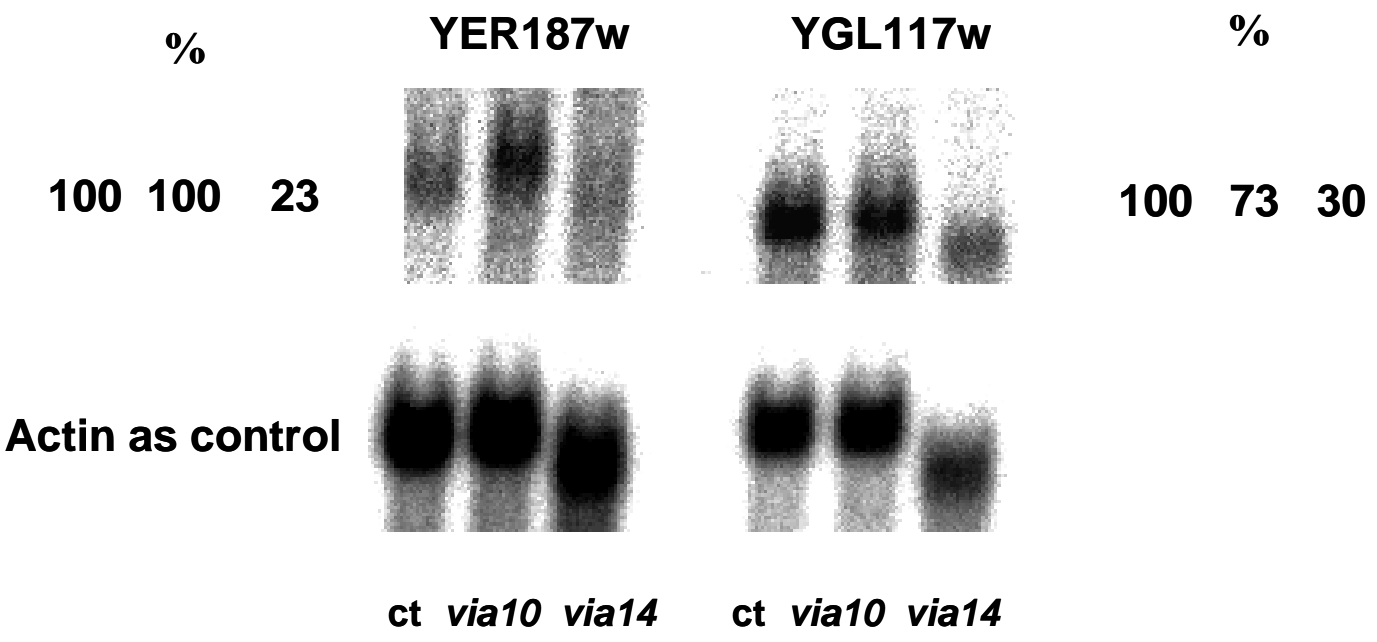

Fig 28: Northern blot showing reduced expression of down-regulated genes at mRNA level. $A$ : In via14, YER187w and YGL117w genes are down-regulated by $23 \%$ and $30 \%$ respectively. In via10, YGL117w is down-regulated by $73 \%$. Actin was used as control to normalize the via-gene signals.

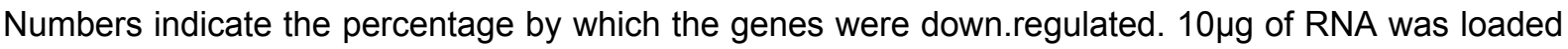
for each sample.

The microarray data could be verified. However, YHR054c and YJL171c were found to be down-regulated in both mutants. The experiments were done twice and the results were similar. 


\subsubsection{Rescue of Ape1p activity in the via mutants}

The four genes YHR054c, YJL171c YER187w and YGL117w, amplified from the wt were cloned into pRS vectors. These were then transformed into via10 and via14 mutants to check if the Ape $1 p$ enzymatic activity is restored.

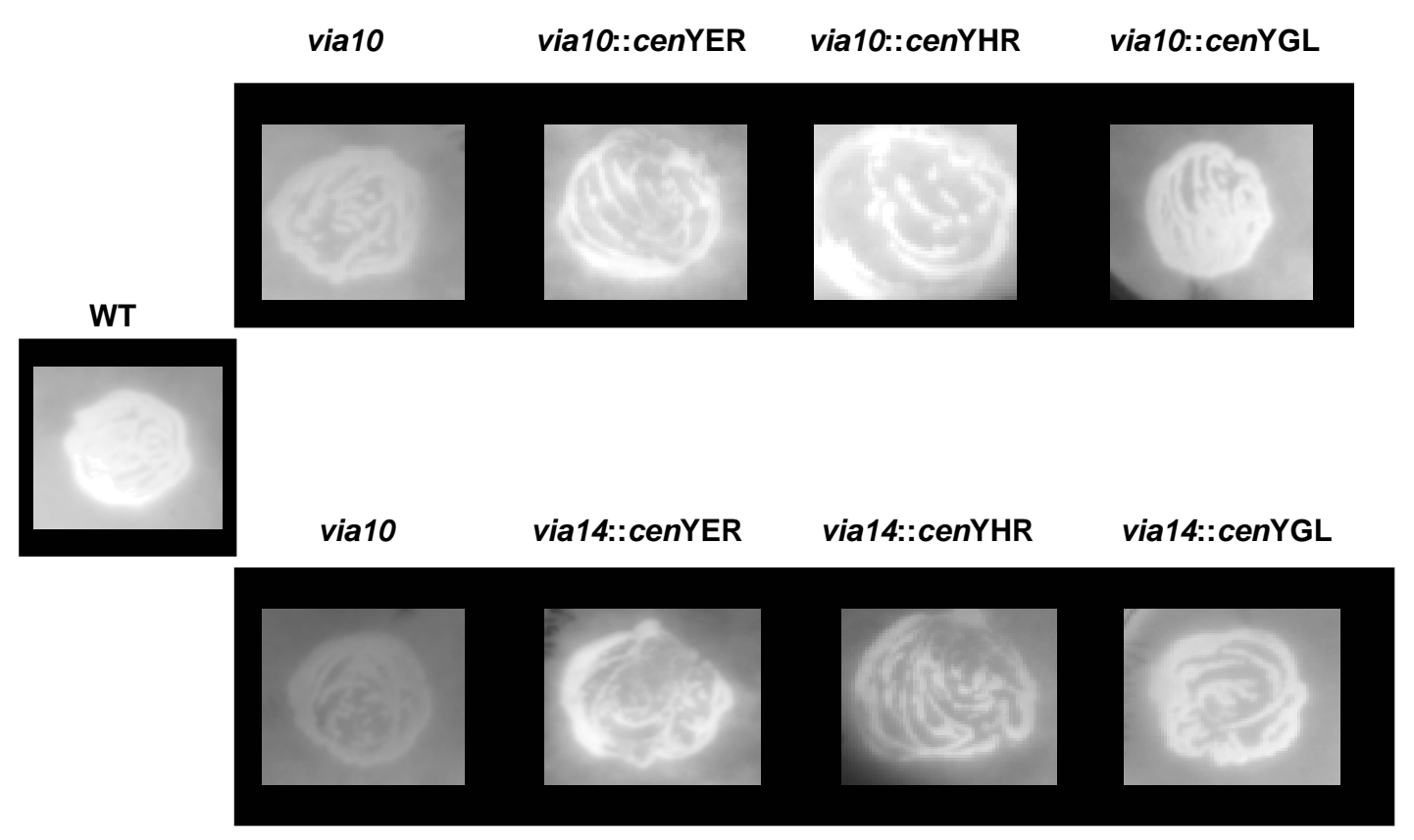

Fig 29: Ape1p overlay assay of Ape1p enzymatic activity. via mutants restore the ape1p activity when transformed with candidate gene.

Overlay assay of wt, via10, via14 and via mutants transformed with the candidate genes was done. It was observed that Ape1p activity is rescued in via mutants upon the expression of the candidate genes (Fig 29).

YJL171C could not been cloned in pRS vectors yet, hence no activity was tested Preliminary data on Ape1p expression levels and vacuolar transport indicate that the 3 genes tested so far, show different suppression/complementation phenotypes in via10 and via14 mutants. More quantitative experiments have to be done to evaluate these data. 


\section{Discussion}

The Saccharomyces cerevisiae vacuolar aminopeptidase I oligomerizes into a homododecameric complex, which is transported from the cytoplasm to the vacuole by the Cvt pathway under nutrient-rich conditions and by autophagy during starvation. Ape $1 \mathrm{p}$ is one of four leucine aminopeptidases found in S. cerevisiae and is the only one to be localized in the vacuole (Frey et al., 1978; Matile et al., 1971). Ape $1 p$ contains an amphipathic $\alpha$-helix, which is necessary and sufficient to target the protein into the vacuole.

The $61 \mathrm{kDa}$ precursor Ape1p homododecamerizes in the cytoplasm and upon transport to the vacuole, the $61 \mathrm{kDa}$ pApe $1 \mathrm{p}$ is converted into a $55 \mathrm{kDa}$ intermediate form by proteinase $A$ and further processed to a $50 \mathrm{kDa}$ mature form by the action of proteinase B (Segui-Real et al., 1995).

Various groups used genetic screens to study cytoplasm to vacuole transport pathways. Mutants were named cvt (Harding et al., 1995, 1996), aut (Thumm et al., 1994) and apg (Tsukada and Ohsumi, 1993), but recently a unified nomenclature was chosen and all are now classified as Atg genes. These studies revealed that pApe $1 p$ is transported to the vacuole directly from the cytoplasm to the vacuole via a vesicle mediated mechanism called the Cvt pathway or under starvation conditions by autophagy. pApe $1 p$ oligomerizes into a homododecamer in the cytoplasm and is enwrapped in a double-membrane vesicle which is then transported to and fuses with the vacuolar membrane like an autophagosome. pApe $1 \mathrm{p}$ is detected in singlemembrane vesicles, so called autophagic bodies within the vacuole of mutants that are defective in the degradation of these vesicles.

Cvt mutants were identified due to accumulation of pApe $1 p$ by western blot colony screening. Autophagy mutants were selected based on the accumulation of autophagic bodies observed by light microscopy (Tsukada and Ohsumi, 1993, Thumm et al., 1994).

A new genetic screen was developed for Ape1p to analyze vacuolar import based on the enzymatic activity of the homododecameric complex of Ape1p (Andrei et al., 2001). This screen led to the isolation of two complementation groups via10 and 
via14. In the via mutants, the cytoplasmic pApe1p precursor accumulates in cytoplasmic vesicles and the homooligomers are not in a native conformation as demonstrated by their sensitivity to proteolysis and their reduced leucineaminopeptidase activity. Both mutants were defective in transport vesicle formation and oligomerization of Ape $1 p$ to an enzymatically active form indicating a functional interdependence of a coordinated oligomerization and transport vesicle formation. In the course of these studies it was discovered that $p A p e 1 p$ is already enzymatically active unlike other precursor forms of vacuolar proteases. Thus the pathway appears to couple formation of the active enzyme and compartmentalization in to a transport vesicle. This is a mechanism to protect the proteins from the proteolytic activity of cytoplasmic pApe1p.

In this study, we identified a previously uncharacterized $16 \mathrm{kDa}$ protein as a singlecopy gene suppressor of the via mutant phenotype and named it Suvia1p for suppressor of via.

Screening based on the enzymatic activity of Ape1p by overlay assay led to the isolation of a suppressor gene, YDR360w. YDR360w was listed as a putative ORF in the yeast genome database. YDR360w ORFs isolated from the wt and via mutants were identical. Northern blots confirmed that there was no difference observed in the mRNA expression level of wt and via mutant strains. The ORF in our yeast strain is longer than the ORF submitted in the yeast genome database, because of an additional ' $C$ ' at position 365 and hence the encoded protein is 144 amino acids long instead of 129 (Fig. 8). Suvia1p does not belong to any characterized protein family. Homologies were found to the helical domain at the C-terminus of the protein in bacteria, yeast and mammals: The yeast anthranilate synthase component II, the mammalian menin I and the Al-2-binding periplasmic protein LuxP. LuxP is part of a Vibrio harveyi extracellular signaling system, autoinducer-2, which binds boron and senses cell density leading to induction of luminescence. Its partner is LuxQ, a membrane embedded histidine protein kinase with a response regulator domain. Mature LuxP is 245 aa long and the crystal structure of LuxP from Vibrio harveyi shows indeed a $\alpha$-helical domain in the region of homology (147-164 aa) to Suvia1p. Menin I (615 aa) or endocrine neoplasia type I protein is expressed in embryogenesis and in multiple tissues. Menin $\mathrm{I}$ is responsible for a heritable predisposition to 
endocrine tumours in man and binds to a number of proteins e.g. replication protein A, JunD, nuclear factor- $\kappa B$ etc. Syntaxin18 is a SNARE protein involved in transport vesicle tethering and fusion. Its helical domain forms a tetrameric complex with the helices of 3 other SNARE proteins (Fasshauer, et al., 1998, Sutton et al., 1998).Homologies were also found to $A$. thaliana proteins and interestingly all of these are unclassified, putative proteins. Helices are often protein-protein interaction domains and the sequence homologies to proteins which are part of protein complexes indicate that this helix domain in Suvia1p is also required for proteinprotein interactions. This was supported by the fact that tagging Suvia1p with YFP rendered it inactive, whereas the smaller HA tag had no negative effect on the Suvia1p function.

In via mutants, pApe1p is degraded rapidly due to its non-native conformation. Upon Suvia1p expression in via mutants, the expression of Ape1p is almost doubled (Fig.11A). Suvia1p enhances the processing of pApe1p and thus vacuolar transport of Ape1p in via mutants (Fig.11B). Suvia1p deficiency renders Ape1p inactive, but it does not cause sentitivity to proteolysis or delayed vacuolar transport. Therefore, Suvia1p induces the native conformation of Ape1p in the via mutants, which makes it more stable against proteolysis. Stimulation of transport appears to be induced only by the formation of more native pApe1p as proposed from the via mutant phenotypes, because Suvia1p deficiency does not delay transport. Ape1p dodecamerization is not reduced in Suvia1p-deficient cells indicating that the conformational changes in Ape1p are subtle compared to those in the via mutants.

To investigate Suvia1p functions we tried to generate specific antisera. Several attempts were made, but all failed. Since no antibody against Suvia1p could be generated, Suvia1p was tagged to hemagglutinin at the C-terminus and this Suvia1pHA was used for further investigation and characterization of Suvia1p. Suvia1p-HA was biologically active as it complemented Suvia1p deficiency (Fig14). Suvia1p-HA was tested with HA antibody by western blot.

Suvia1p has a molecular mass of $16 \mathrm{kDa}$ as predicted from its ORF YDR360W. But on SDS-PAGE it shows a different migration pattern and migrates at about $48 \mathrm{kDa}$ (Fig15). We assumed that this variation in the molecular mass of Suvia1p-HA is 
possible, if Suvia1p-HA forms a trimeric complex or due to incomplete denaturation of the protein by SDS or by some post-translational modification.

Gel filtration experiments were done using a Superdex 75 column in the presence of $6 \mathrm{M}$ urea. Under these conditions, Suvia1p-HA was observed in the eluate fractions corresponding to a molecular mass of $\sim 14 \mathrm{kDa}$ (Fig17). Suvia1p-HA migration behaviour on SDS-PAGE is therefore likely due to a trimeric complex of Suvia1p-HA and not due to a post-translational modification of the protein.

Subcellular fractionation studies revealed that Suvia1p is a cytosolic protein. Suvia1p-HA was only found in the supernatant $200,000 \times \mathrm{g}$ cytosolic fraction (Fig18). This subcellular localization was further confirmed by indirect immunofluorescence microscopy experiments. Suvia1p-HA was observed to be concentrated in small structures, but fluorescence was also observed throughout the cytoplasm (Fig19).

The earliest structure in Cvt vesicle formation known is the so called preautophagosomal structure or PAS. GST-tagged Atg proteins Atg1, Atg2, Atg5, Atg8 and Atg16 were shown to assemble in the pre-autophagosomal structure (PAS) in the vicinity of the vacuole (Suzuki et al., 2001). Analysis of apg mutants revealed that the formation of both a phosphotidyl-ethanolamine-conjugated Atg8 and Atg12pAtg5p conjugate is essential for the localization of Atg8 to the PAS (Suzuki et al., 2001). Because Suvia1p appears to be involved in the early events of pApe1p vesicular transport, we wanted to test whether Suvia1p is associated with the PAS. Atg8 (Aut7) is used as a marker protein for the PAS and is required for Cvt vesicle formation (Suzuki et al., 2001). Immunofluorescence microscopy for Suvia1p-HA and Atg8p-GFP localization revealed that Suvia1p and Aut7p were in close proximity. In some cases the two proteins even appeared to be colocalized (Fig 20C). However, coimmunoprecipitation experiments failed to demonstrate an interaction of the two proteins to the same complex. Therefore the resolution of the microscopic images is probably to low to resolve the two closely localized structures.

Purification of Suvia1p and analysis of the complex composition should be extended by gel filtration experiments followed by mass spectroscopy to untangle the questions, if it forms a complex with itself by oligomerization or forms a complex with other proteins. 
Suvia1p-Ape1p interactions by GST-pull down experiments revealed that there exists a weak interaction between Suvia1p and Ape1p in vitro. Ape1p from suvia1 4 cells was not eluted from the beads as efficiently as Ape1p from wt cells. A large fraction of Ape1p from suvia1A cells was irreversibly bound to the GST-Sepharose beads (Fig 23). The inefficient elution of Ape1p from suvia1 $\Delta$ cells indicates that the nonnative Ape1p tends to form aggregates in vitro imparing its binding to Suvia1p as well as elution from the beads.

via mutants have a reduced transformation rate, which is further reduced by increasing plasmid size. Therefore a DNA library was constructed with smaller genomic DNA inserts than are normally used. This library enabled us to isolate SUVIA1, but unfortunately the via genes were not cloned. Therefore we tried to exploit the DNA array technology to identify the via genes. It could very well be that mutations in the ORF and mutations in the promoter regions of the via genes could lead to reduced stability or lower expression levels of the mRNAs respectively. Microarray data revealed that 162 genes were differentially expressed, either upregulated or down-regulated, when the via10 and via14 mutants were compared with each other and with the wt (Fig 27). When via10/wt were compared, 2 out of 4 downregulated genes were uncharacterized. Similarly, when via14/wt was compared, 16 genes were down-regulated, out of which 2 were uncharacterized. No Atg or related genes were found to be differentially expressed in the via mutants.

YHR054c and YJL171c were down-regulated in via10, YER187w and YGL117w were down-regulated in via14. These four genes were amplified from the genomic DNA of the wt, via10 and via14 strains by PCR. The amplified PCR products were cloned and sequenced to check, if there were any mutations in the ORFs. The expression levels of mRNA in these genes were further analyzed by northern blots. When these genes were transformed in via mutants, to check if the Ape1p activity was rescued in these mutants by overlay assay, it was observed that the Ape $1 p$ enzymatic activity in the via mutants were comparable to the wt (Fig 31). Ape1p expression levels were also tested by western blots and it was found that Ape1p expression is enhanced by the candidate genes in via14. However, in via10 the expression level of Ape1p remained the same (Fig 32). 
Further investigations have to be done on these 4 uncharacterized genes to learn the significance and role of the respective proteins. Expression and processing of Ape $1 p$ in the absence of these genes should provide us with more information about the impact of the uncharacterized proteins on Ape1p assembly and transport. 


\section{Conclusions}

Unlike other vacuolar proteins, vacuolar aminopeptidase I is known to be transported to the vacuole by cytoplasmic double membrane vesicles by the Cvt pathway. The precursor form, pApe1p oligomerizes in the cytosol into a dodecamer and is enclosed in a double membrane to form a cvt vesicle, which is then transported to and fuses with the vacuole releasing a single-membrane autophagic body into the vacuolar lumen. This is degraded and the precursor sequence of Ape1p is removed. The cytosolic precursor protein and the matured vacuolar protein form homododecameric complexes and only this complex has enzymatic activity.

In this project, my aim was to identify the via genes by complementation cloning. Using this approach, a single-copy suppressor of the via mutant phenotype has been isolated encoded by the putative ORF YDR360w. It encodes a $16 \mathrm{kDa}$ protein, which does not belong to any described protein family. We named it Suvia1p for 'suppressor of via'.

Suvia1p is a cytosolic protein and found to be part of a $200 \mathrm{kDa}$ cytoplasmic complex localized in close proximity to the pre-autophagosomal complex.

In both via mutants, pApe1p is more sensitive to degradation and accumulates in cytoplasmic Cvt vesicles. Ape1p protein levels and Ape1p enzymatic activity is increased in both via mutants due to Suvia1p expression from a single copy plasmid. This demonstrates reduced sensitivity to proteases indicating proper $\mathrm{pApe} 1 \mathrm{p}$ folding and complex assembly. Thus Suvia1p supports the formation of native dodecamers of pApe1p. Suvia1p also enhances the processing of pApe1p and its vacuolar transport in the via10 supporting the model that $p A p e 1 p$ dodecamerization into the enzymatically active form is linked to Cvt vesicle formation. However, Suvia1p does not stimulate vacuolar transport of Ape1p under conditions of autophagy. Suvia1p is not required for the dodecamerization of Ape1p. There exists a weak interaction between Ape1p and Suvia1p in vitro. Thus we interpret from our studies that Suvia1p is involved in the formation of native dodecamers of $p A p e 1 p$.

In an attempt to identify the via genes by DNA microarray, 162 genes were found to be differentially expressed, out of which 2 were down-regulated in via10 and via14 
respectively. These are uncharacterized proteins and also does not belong to any classified family. Mutations were found in the ORFs of these genes isolated from via10 and via14 and also mRNA expression levels were significantly reduced. When the ORFs were expressed in the via mutants, Ape1p enzymatic activity was comparable to the wt. Ape1p expression levels was also improved in case of via 14 but had no significant effect in via10. Further experiments have to be done to learn more about the unknown proteins and their effect on pApe1p folding and complex assembly. 


\section{Bibliography}

Abeliovich, H., Darsow, T. and Emr, S.D. (1999). Cytoplasm to vacuole trafficking of aminopeptidase I requires a t-SNARE-Sec1p complex composed of Tlg2p and Vps45p. EMBO J. 18, 6005-6016.

Ammerer, G., Hunter, C.P., Rothman, J.H., Saari, G.C., Valls, L.A. and Stevens, T.H. (1986). PEP4 gene of Saccharomyces cerevisiae encodes Proteinase A, a vacuolar enzyme required for processing of vacuolar precursors. Mol. And Cell. Biol. 6, 2490-2499.

Baba, M., Ohsumi, M., Scott, S.V., Klionsky, D.J. and Ohsumi, Y. (1997). Two distinct pathways for targeting proteins from the cytoplasm to the vacuole/ lysosome. J. Cell Biol. 139, 1687-1695.

Baba, M., Takeshige, K., Baba, N. and Ohsumi, Y. (1994). Ultrastructural analysis of the autophagic process in yeast: detection of autophagosomes and their characterisation. J. Cell Biol. 124, 903-913.

Banta, L.M., Robinson, J.S., Klionsky, D.J. and Emr, S.D. (1988). Organelle assembly in yeast: Characterisation of yeast mutants defective in vacuolar biogenesis and protein sorting. J. Cell Biol. 107, 1369-1383.

Chang, Y.H. and Smith, J.A. (1989). Molecular cloning and sequencing of genomic DNA encoding Aminopeptidase I from Saccharomyces cerevisiae. J. Biol. Chem. 264, 6979-6983.

Chvatchko, Y., Howald, I. and Riezman, H. (1986). Two yeast mutants defective in endocytosis are defective in pheromone response. Cell 46, 355364. 
Conibear, E. and Stevens, T.H. (1995). Vacuolar biogenesis in yeast: Sorting out the proteins. Cell 83, 513-516.

Conradt, B., Haas, A. and Wickner, W. (1994). Determination of four biochemically distinct, sequential stages during vacuole inheritance in vitro. $J$. Cell Biol. 126, 99-110.

Cooper, A.A and Stevens, T.H. (1996). Vps10p cycles between the late-Golgi and prevacuolar compartments in its function as the sorting receptor for multiple yeast vacuolar hydrolases. J. Cell Biol. 133, 529-541.

Cowles, C.R., Snyder, W.B., Burd, C.G. and Emr, S.D. (1997a). Novel Golgi to vacuole delivery pathway in yeast: identification of a sorting determinant and required transport component. EMBO J. 16, 27692782.

Cowles, C.R., Odorizzi, G., Payne, G.S. and Emr, S.D. (1997b). The AP-3 adaptor complex is essential for cargo-selective transport to the yeast vacuole. Cell 91, 109-118.

Cueva, R., Garcia-Alvarez, N. and Suarez-Rendueles, P. (1989). Yeast vacuolar aminopeptidase ysc I. Isolation and regulation of the APE1 (LAP4) structual gene. FEBS Letter. 259, 125-129.

Darsow, T., Rieder, S.E. and Emr, S.D. (1997). A multispecificity syntaxin homologue, Vam3p, essential for autophagic and biosynthetic protein transport to the vacuole. J. Cell Biol. 138, 517-529. 
Egner, R., Thumm, M., Straub, M., Simeon, A., Schüller, H.J. and Wolf, D.H. (1993). Tracing intracellular proteolytic pathways. Proteolysis of fatty acid synthase and other cytoplasmic proteins in the yeast Saccharomyces cerevisiae. J. Biol. Chem. 268, 27269-27276.

Fasshauer, D., Sutton, R.B., Brugner, A. T., and Jahn, R. (1998) Proc Natl Acad Sci. 95, 15781-15786

Frey, J. and Röhm, K.H. (1978). Subcellular localization and levels of aminopeptidases and dipeptidase in Saccharomyces cerevisiae. Biochem. Biophys. Acta. 527, 31-41.

Funakoshi, T., Matsuura, A., Noda, T. and Ohsumi, Y. (1997). Analyses of APG13 gene involved in autophagy in yeast, Saccharomyces cerevisiae. Gene 192, 207-213.

George, M.D., Baba, M., Scott, S.V., Mizushima, N., Garrison, B.S., Ohsumi, Y. and Klionsky, D.J. (2000). Apg5p functions in the sequestration step in the cytoplasm-to-vacuole targeting and macroautophagy pathways. Mol. Biol. Cell 11, 969-982.

Harding, T.M., Hefner-Gravink, A., Thumm, M. and Klionsky, D.J. (1996). Genetic and phenotypic overlap between autophagy and the cytoplasm to vacuole protein targeting pathway. J. Biol. Chem. 271, 17621-17624.

Hasilik, A. and Tanner, W. (1978). Biosynthesis of the vacuolar yeast glycoprotein carboxypeptidase $\mathrm{Y}$. Conversion of the precursor into the enzyme. Eur. J. Biochem. 85, 599-608.

Horazdovsky, B.F., DeWald, D.B. and Emr, S.D. (1995). Protein transport to the yeast vacuole. Curr. Opi. In Cell Biol. 7, 544-551. 
Huang, P.H. and Chiang, H.L (1997). Identification of novel vesicles in the cytosol to vacuole protein degradation pathway. J. Cell Biol. 136, 803-810.

Khalfan, W.A. and Klionsky, D.J. (2002). Molecular machinery required for autophagy and the cytoplasm to vacuole targeting (Cvt) pathway in $S$. cerevisiae. Curr. Opi. In Cell Biol. 14, 468-475.

Kihara, A., Noda, T., Ishihara, N., and Ohsumi, Y. (2001). Two distinct Vps34 phosphatidylinositol 3-kinase complexes function in autophagy and carboxypeptidase $\mathrm{Y}$ sorting in Saccharomyces cerevisiae. J. Cell Biol. 152, 519-530

Kim, J., Dalton, V.M., Eggerton, K.P., Scott, S.V. and Klionsky, D.J. (1999). Apg7p/ Cvt2p is required for the cytoplasm-to-vacuole targeting, macroautophagy, and peroxisome degradation pathways. Mol. Biol. Cell 10, 1337-1351.

Kim, J., Scott, S.V., Oda, M.N. and Klionsky, D.J. (1997). Transport of a large oligomeric protein by the cytoplasm to vacuole protein targeting pathway. $J$. Cell Biol. 137, 609-618.

Kirisako, T., Baba, M., Ishihara, N., Miyazawa, K., Ohsumi, M., Yoshimori, T., Noda, T. and Ohsumi, Y. (1999). Formation process of autophagosome is traced with Apg8/Aut7p in yeast. J. Cell Biol. 147, 435-446.

Klionsky, D.J., Cregg, J.M., Dunn, W.A. Jr., Emr, S.D., Sakai, Y., Sandoval, I.V., Sibirny, A., Subramani, S., Thumm, M., Veenhuis, M. and Ohsumi, Y. (2003). A Unified nomenclature for Yeast Autophagy-Related Genes. Dev Cell 5, 1-20. 
Klionsky, D.J. and Ohsumi, Y. (1999). Vacuolar import of proteins and organelles from the cytoplasm. Annu. Rev. Cell Dev. Biol. 15, 1-32.

Klionsky, D.J., Cueva, R. and Yaver, D.S. (1992). Aminopeptidase I of Saccharomyces cerevisiae is localised to the vacuole independent of the secretory pathway. J. Cell Biol. 119, 287-299.

Klionsky, D.J., Herman,P.K. and Emr, S.D. (1990). The fungal vacuole: composition, function and biogenesis. Microbiol. Rev. 54, 266-292.

Klionsky, D.J. and Emr, S.D. (1989). Membrane protein sorting: biosynthesis, transport and processing of yeast vacuolar alkaline phosphatase. EMBO J. 8, 2241-2250.

Klionsky, D.J., Banta, L.M. and Emr, S.D. (1988). Intracellular sorting and processing of a yeast vacuolar hydrolase: proteinase A propeptide contains vacuolar targeting information. Mol. Cell Biol. 8, 2105-2116.

Konopka, J.B., Jenness, D.D. and Hartwell, L.H. (1988). The C-terminus of the $S$. cerevisiae alpha-pheromone receptor mediates an adaptive response to pheromone. Cell 54, 609-620.

Lang, T., Schaeffeler, E., Bernreuther, D., Bredschneider, M., Wolf, D.H. and Thumm, M. (1998). Aut2p and Aut7p, two novel microtubuleassociated proteins are essential for delivery of autophagic vesicles to the vacuole. EMBO J. 17, 3597-3607. 
Levine, B., and Klionsky, D.J. (2004). Development by Self Digestion: Molecular Mechanisms and Biological Functions of Autophagy. Dev Cell 6, 463-477.

Martinez, E., Segui-Real, B., Silles, E., Mazon, M.J. and Sandoval, I.V. (1999). The prepropeptide of vacuolar aminopeptidase I is necessary and sufficient to target the fluorescent reporter protein GFP to the vacuole of yeast by the Cvt pathway. Mol. Microbiol. 33, 52-62.

Martinez, E., Jimenez, M.A., Segui-Real, B., Vandekerckhove, J. and Sandoval, I.V. (1997). Folding of the presequence of yeast pAPI into an amphipathic helix determines transport of the protein from the cytosol to the vacuole. J. Mol. Biol. 267, 1124-1138.

Mechler, B., Hirsch, H.H., Müller, H. and Wolf, D.H. (1988). Biogenesis of the yeast lysosome (vacuole): biosynthesis and maturation of proteinase yscB. EMBO J. 7, 1705-1710.

Mechler, B., Müller, H. and Wolf, D.H. (1987). Maturation of vacuolar (lysosomal) enzymes in yeast: proteinase yscA and proteinase yscB are catalysts of the processing and activation event of carboxypeptidase yscY. EMBO J. 6, 2157-2163.

Mechler, B., Müller, M., Müller, H., Muessdoerffer, F. and Wolf, D.H. (1982). In vivo biosynthesis of the vacuolar proteinases $A$ and $B$ in the yeast Saccharomyces cerevisiae. J. Biol. Chem. 257, 11203-11206.

Metz, G. and Röhm, K.H. (1976). Yeast aminopeptidase I. Chemical composition and catalytic properties. Biochem. Biophys. Acta. 429, 933-949. 
Mizushima, N., Noda, T. and Ohsumi, Y. (1999). Apg16p is required for the function of the Apg12p-Apg5p conjugate in the yeast autophagy pathway. EMBO J. 18, 3888-3896.

Mizushima, N., Noda, T., Yoshimori, T., Tanaka, Y., Ishii, T., George, M.D., Klionsky, D.J., Ohsumi, M. and Ohsumi, Y. (1998). A protein conjugation system essential for autophagy. Nature 395, 395-398.

Noda, T., Kim, J., Huang, W-P., Baba, M., Tokunaga, C., Ohsumi, Y. and Klionsky, D.J. (2000). Apg9p/Cvt7p is an integral membrane protein required for transport vesicle formation in the Cvt and autophagy pathways. J. Cell Biol. 148, 465-479.

Noda. T. and Ohsumi, Y. (1998). Tor, a phosphatidylinositol kinase homologue, controls autophagy in yeast. J. Biol. Chem. 273, 3963-3966.

Noda T., Matsuura, A., Wada, Y. and Ohsumi, Y. (1995). Novel system for monitoring autophagy in the yeast Saccharomyces cerevisiae. Biochem. Biophys. Res. Commun. 210, 126-132.

Oda, M.N., Scott, S.V., Hefner-Gravink, A., Caffarelli, A.D. and Klionsky, D.J. (1996). Identification of a cytoplasm to vacuole targeting determinant in aminopeptidase I. J. Cell Biol. 132, 999-1010.

Piper, R.C., Bryant, N.J. and Stevens, T.H. (1997). The membrane protein Alkaline Phosphatase is delivered to the vacuole by a route that is distinct from the VPS-dependent pathway. J. Cell Biol. 138, 531-545.

Preston, R.A., Manolson, M.F., Becherer, K., Weidenhammer, E., Kirkpatrick, D., Wright, R. and Jones, E.W. (1991). Isolation and characterisation of 
PEP3, a gene required for vacuolar biogenesis in Saccharomyces cerevisiae.

Mol. Cell Biol. 11, 5801-5812.

Raymond, C.K., Howald-Stevenson, I., Vater, C. and Stevens, T.H. (1992b). Morphological classification of the yeast vacuolar protein sorting mutants: evidence for a prevacuolar compartment in class $\mathrm{E}$ vps mutants. Mol. Biol. Cell 3, 1389-1402.

Rothman, J.H. and Stevens, T.H. (1986). Protein sorting in yeast: mutants defective in vacuole biogenesis mislocalize vacuolar proteins into the late secretory pathway. Cell 47, 1041-1051.

Schork, S.M., Thumm, M. and Wolf, D.H. (1995). Catbolite inactivation of fructose-1,6-bisphosphatase of Saccharomyces cerevisiae. Degradation occurs via the ubiquitin pathway. J. Biol. Chem. 270, 26446-26450.

Scott, S.V., Nice, D.C $3^{\text {rd }}$., Nau, J.J., Weisman, L.S., Kamada, Y., KeizerGunn, I., Funakoshi, T., Veenhuis, M., Ohsumi, Y. and Klionsky, D.J. (2000). Apg13p and Vac8p are part of a complex of phosphoprotein that are required for cytoplasm to vacuole targeting. J. Biol. Chem. 275, 25840-25849.

Scott, S.V., Baba, M., Ohsumi, Y. and Klionsky, D.J. (1997). Aminopeptidase $\mathrm{I}$ is targeted to the vacuole by a nonclassical vesicular mechanism. J. Cell Biol. 138, 37-44.

Scott, S.V., Hefner-Gravink, A., Morano, K.A., Noda, T., Ohsumi, Y. and Klionsky, D.J. (1996). Cytoplasm to vacuole targeting and autophagy employ the same machinery to deliver proteins to the yeast vacuole. Proc. Natl. Acad. Sci. USA 93, 12304-12308. 
Scott, S.V., Guan, J., Hutchins, M.U., Kim, J., and Klionsky, D.J. (2001) Cvt19 is a receptor for the Cytoplasm-to-Vacuole Targeting Pathway. Mol.Cell. 7, 1131-1141.

Seguí-Real, B., Martinez, M. and Sandoval, I.V. (1995). Yeast aminopeptidase $\mathrm{I}$ is post translationally sorted from the cytosol to the vacuole by a mechanism mediated by its bipartite N-terminal extension. EMBO J. 14, 5476-5484.

Sirkiroski, R.S. and Hieter, P. (1998). A system of shuttle vectors and yeast host strains designed for efficient manipulation of DNA in Saccharomyces. Cerevisiae. Genetics 122, 19-27.

Stevens, T.H., Rothman, J.H., Payne, G.S. and Schekman, R. (1986). Gene dosage-dependent secretion of yeast vacuolar carboxypeptidase Y. J.Cell Biol. 102, 1551-1557.

Subramani, S. (1993). Protein import into peroxisomes and biogenesis of the organelle. Annu. Rev. Cell Biol. 9, 445-478.

Sutton, R. B., Fasshauer, D., Jahn, R., and Brunger, A.T. (1998). Crystal structure of a SNARE complex: SNARE proteins reclassified as Q-and RSNARES. Nature 395, 15781-15786.

Suzuki, K., Kirisako, T., Yoshiaki, K., Mizushima, N., Noda, T. and Ohsumi, Y. (2001). The pre-autophagosomal structure organized by concerted functions of APG genes is essential for autophagosome formation. EMBO J. 21, 5971-5981.

Takeshige, K., Baba, M., Tsuboi, S., Noda, T. and Ohsumi, Y. (1992). Autophagy in yeast demonstrated with proteinase-deficient mutants 
and conditions for its induction. J. Cell Biol. 119, 301-311.

Teichert, U., Mechler, B., Müller, H. and Wolf, D.H. (1989). Lysosomal (vacuolar) proteinases of yeast are essential catalysts for protein degradation, differentiation, and cell survival. J. Biol. Chem. 264, 16037-16045.

Thumm, M., Egner, R., Koch, B., Schlumpberger, M., Straub, M., Veenhuis, M. and Wolf, D.H. (1994). Isolation of autophagocytosis mutants of Saccharomyces cerevisiae. FEBS Lett. 349, 275-280.

Trumbly, R.J. and Bradley, G. (1983). Isolation and characterisation of aminopeptidase mutants of Saccharomyces cerevisiae. J. Bacteriol. 156, 3648.

Tsukada, M. and Ohsumi, Y. (1993). Isolation and characterisation of autophagy-defective mutants of Saccharomyces cerevisiae. FEBS Lett. 333, 169-174.

Van Den Hazel, H.B., Kielland-Brandt, M.C. and Winther, J.R. (1992). Autoactivation of proteinase $A$ initiates activation of yeast vacuolar zymogens. Eur. J. Biochem. 207, 227-283.

Wang, C.W., and Klionsky , D.J. (2003). The molecular mechanism of autophagy. Mol. Med. 9, 65-76.

Yoshihisa, T. and Anraku, Y. (1990). A novel pathway of import of $\alpha-$ mannosidase, a marker enzyme of vacuolar membrane, in Saccharomyces cerevisiae. J. Biol. Chem. 265, 22418-22425 
Zubenko, G.S. and Jones, E.W. (1981). Protein degradation, meiosis and sporulation in proteinase-deficient mutants of Sacchromyces cerevisiae. Genetics 97, 45-64. 


\section{Acknowledgement}

This work would have been impossible without the help and support of the following people. I thank:

Prof. Dr. Kurt von Figura for giving me an opportunity to work in Biochemie-Il and helping me with the critical reading and correction of my thesis.

Prof. Dr. G. Gottschalk for being the co-referee of my thesis.

Dr. Peter Schu for guiding me through out this project with lots of patience and support. Thank you for your help in the preparation of the thesis. I have learnt in your lab how to deal and think scientifically which makes me feel confident about my future prospects. Thank you so much Sir.

Olaf, Inga, Monika and Jutta for your cooperation and creating a friendly environment in the lab which was very important for surviving all these years.

My special and sincere thanks to Constanze for being a guide and friend both inside and outside the lab. Thank you for everything.

Dr. Guruprasad, Subbulakshmi, Karthik and Malaiyalam for giving me useful tips for my experiments.

Thank you Dr. Meik Dilcher for helping me in every possible way and for being such a caring and loving friend. Thanks to Dr. Anna Boulankina for supporting me with the software.

Dr. Gabriele Fischer Von Mollard, Dr. Thomas Dierks and Dr. Bernhard Schmidt for their help.

All my colleagues in Biochemie II for their help and cooperation.

Dr. Pratap Sahoo for helping me in the final formatting of the thesis.

My friends Pradip and Surya who were always there by my side and always had time to listen to me and my problems. I thank you from the bottom of my heart for being such wonderful friends.

My mom, dad and sis for their moral support and encouragment through out my life. Thank you for trusting me and giving a shape to my life. My thanks to rest of the family members, friends, my well wishers and the Almighty. 


\section{Lebenslauf:}

Name:

Date of Birth:

Geburtsort:

$1993-1995$

1995-1998

$1998-2000$

June 2001-present
Pasupuleti Naga Rekha

20.10.1977

Hyderabad, India

Pre-universtiy education, Kendriya Vidyalaya Picket, Secunderabad, India

Bachelor of Science in Botany, Zoology and Chemistry, Osmania University College for Women, Hyderabad, India.

Master of Science in Biochemistry, University of Hyderabad, India.

Joined the "Zentrum Biochemie und Molekulare Zell Biologie" (Biochemie) to pursue doctoral studies under the supervision of PD. Dr. Peter Schu to work on the research project "Identification of a new factor essential for vacuolar aminopeptidase I activity " 